a

ars

3

(2)

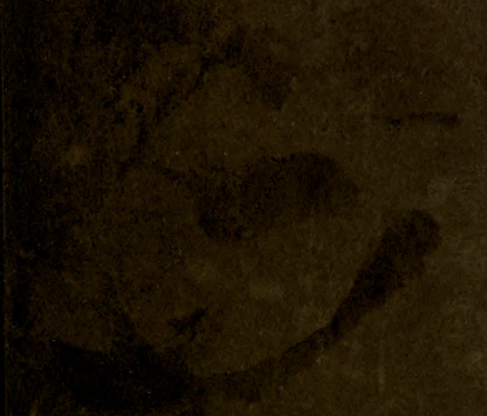

(2) 
L. $1054^{A^{*}}$
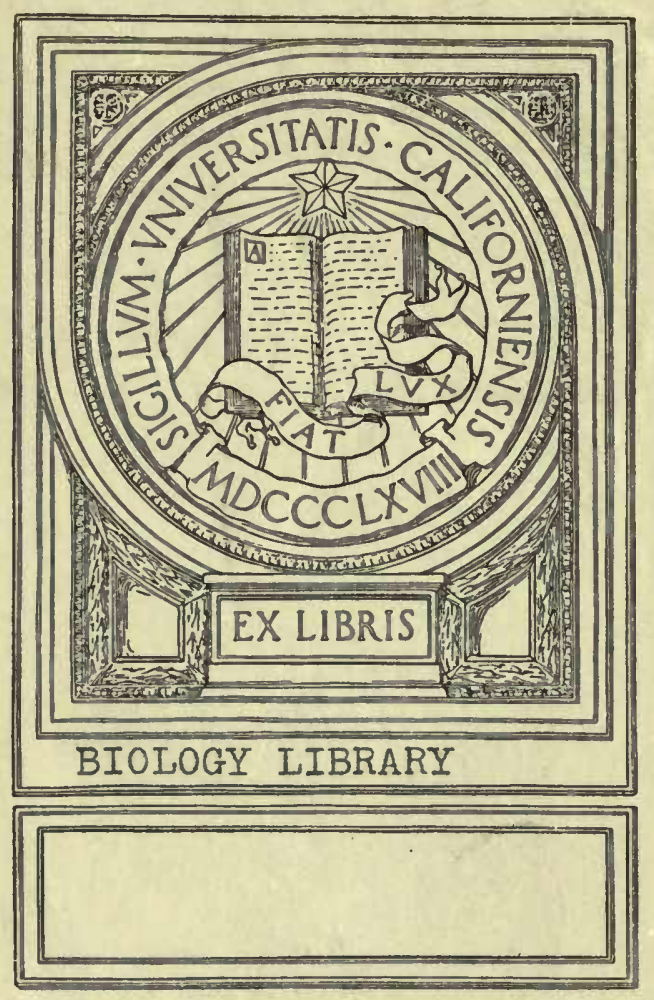

g 




\title{
FAUNA ORCADENSIS:
}

\author{
- \\ THE NATURAL HISTORY
}

OF THE

QUADRUPEDS, BIRDS, REPTILES, AND FISHES,

OF

ORKNEY AND SHETLAND.

BY

THE REV. GEORGE LOW,

MINISTER OF BIRSA AND HARAY.

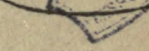

From a Manuscript in the possession of WM. Elford Leach, M. D. F. L. S. \& c.

\section{EDINBURGH :}

PRINTED BY GEORGE RAMSAY AND COMPANY, TOR ARCHIBALD CONSTABLE AND COMPANY, EDINBURGH ; AND FOR LONGMAN, HURST, REES, ORME, AND BROWN,-AND WHITE, COCHRANE, AND CO. LONDON.

1813. 

TO THE RIGHT HONOURABLE

SIR JOSEPH BANKS, K. B. \&c. \&c.

WHOSE GENEROUS PATRONAGE OF SCIENCE

HAS EXTENDED

EVEN TO THE OBSCURE LABOURS OF THE AUTHOR,

THIS BOOK,

AS AN HUMBLE TRIBUTE OF ADMIRATION,

IS MOST RESPECTFULLY INSCRIBED

BY HIS OBEDIENT HUMBLE SERVANT,

THE EDITOR. 



\section{ADVERTISEMENT.}

Mr Low's merits, as a laborious and accurate observer of Nature, were, it is believed, scarcely known beyond the narrow circle of his particular friends; and it is to be regretted, that a recent historian* has not scrupled to avail himself of the advantages which this obscurity offered to a plagiary. It having been the Editor's fortune to procure the MS. Fauna Orcadensis of Mr Low, he now begs leave to lay it before the public, in the form in which it was left by its Reverend Author. It appears to have been revised by the late Mr Pennant, as it contains a few corrections in that gentleman's handwriting. The Editor trusts that it will be found to afford an interesting and valuable addition to the Natural History of the British Islands, and prove far more useful than the closet compilations of some modern zoologists.

IT may not be uninteresting to relate the ferw facts which the Editor has been enabled to collect $t$, respecting the author of the following pages. Mr Low was born, in 1746, in the parish of Edzel, in Forfarshire. After prosecuting his studies at the Colleges of Aberdeen and St Andrew's, he became tutor in the family of a gentleman of the name of Gran AM, at Stromness, in Orkney. While he remained at this place, Sir Joseru (then Mr) Banks and Dr Solander touched at the islands, on their return from the last and ill-fated voyage of discovery, in which Captain Cooke fell. Mr Low having early acquired a taste for Natural History, was much noticed by these distinguished philosophers, and was requested to accompany them in their excursions through the Orkneys, and also to the Shetland Islands, which he did.

ON the 14th of December 1774, Mr Low was ordained minister of Birsay and Haray, a parish in Pomona, or the Mainland of Orkney. The duties of this charge he continued to fulfil thronghout the remainder of his life.

- The Rev. George Barry, D. D. in his History of Orkney, 4to. 1805.

+ For these particnlars the Editor is indebted to Patrick Neill, Esq. author of a Tour in Orkney and Shetland, whose ardour in the pursuits of science is too well known to require any praise in this place, and to Mr Hugh Moare at Birsay, an intimate friend of Mr Low's. 


\section{viii}

In 1775, he married Miss HeLEN TyRie, only daughter of the Rev. JuMES Tyrie, minister of Stromness and Sandwick. The death of this Lady (which happened in child-bed, the year after the marriage) deeply affected Mr Low, and it is believed he found consolation chiefly in that devotion to the pursuits of $\mathrm{Na}$ tural History for which he was remarkable. During the last nineteen years of his life he continued to labour in the study of Nature, and his success was ccrtainly creditable, considering the many disadvantageous circumstances against which, in his remote situation, he had to strive.

SIR JoSEPI BANKs, with his wonted discrimination and zeal for the promotion of science, took an opportunity of introducing $\mathrm{Mr}$ Low to the acquaintance of the celebrated Mr Pennant. By Mr Pennant's encouragement, chiefly, Mr Low engaged to draw up both a Fauna Orcadensis and a Flora Orcadensis. The former is now presented to the public : the latter has entirely disappeared. $\mathrm{He}$ likewise prepared for the press "A Tour through the Islands of Orkney and Shetland, containing Hints relating to their Ancient, Modern, and Natural History." He likewise undertook and executed a translation of Torfæus's History of Orkney. Mr Low died in 1795.

THE principal part of his MSS. including the Fauna, the Tour, and Translation of Torfæus, together with his Zoological Collections, (in which was a specimen of Asterias Caput Meduse, taken in the Orkney Seas, and now in the Editor's possession), fell into the hands of the late eminent antiquary, Mr G e orG E PATon of Edinburgh, at whose sale, after his death, they were purchased by different individuals.

The Editor caunot conclude this advertisement without acknowledging the liberality of the Booksellers, in readily undertaking to publish this Orkney Fauna, in a form and style calculated to do credit to the unfortunate Author.

WILLIAM ELFORD LEACH.

Edinburgh, May 14, 1812. 


\section{AUTHOR'S PREFACE.}

The utility of provincial histories of all kinds is now generally acknowledged to be great, as these are certainly the materials from which a general structure, either of civil, military, or natural history, is to be raised. In no branch of history is this more apparent than in that of Nature. She must be sought and described on the spot, and her various productions investigated in their proper climates, soils, and beds. Hearsay descriptions of natural subjects are seldom to be depended on, unless taken from the most attentive observers, and even these, to be convincing, must be made on the spot, as change of climate or soil sometimes makes such alterations in the appearance of natural objects, as may deceive even adepts in the science.

The following sketch of the Natural History of the Orkney Islands was at first designed as an information of what might be remarkable here to a gentleman*, whose writings on the same subject do him honour, and are well known to the public. But by degrees swelling to some bulk, by his advice it was thrown into a systematic arrangement, and now appears as a separate work.

* Thomas Pennant, Esq. 
I am very sensible many excellent writers of provincial natural history, as Borlase, and others, have not inclined to be fettered with system. I likewise imagine many readers would rather see a work of this kind unconfined by it ; but as the following sheets were not only designed to inform the distant reader, but likewise as a directory to persons of curiosity residing here, and who may have an opportunity to make additional observations, but who have it not in their power either to acquire other than a general knowledge of natural history, or consult the systematic writers, and for that reason are ever at a loss where to place any bird, fish, plant, \&c. especially if it is in the least uncommon ; if this is thoroughly considered, the objection some may have to system will vanish.

To assist the young Orkney Faunist in classing, I have followed Ray's System, and have been obliged to Mr Pennant's books for this. For the generic marks I am indebted to his Genera of Birds, Edinburgh 1773, and his British Zoology. These, I imagine, will greatly assist any person of curiosity in reducing any beast, bird, or fish to its proper class, order, and genus, as the following descriptions $I$ hope will enable him to discover whether any species be already known in these isles.

What other helps I had from books are generally acknowledged under their proper heads.

I cannot conclude this short account of the following work, without acknowledging the generous assistance I have met 
with in the prosecution of it from several of those gentlemen who of late have made such a figure in the study of nature. To Mr BAn Ks* (besides many other obligations), I owe my being introduced to MrPENNANT, who, in the most friendly manner, lent all kinds of assistance necessary for carrying on such a work. To Mr George Paton, at Edinburgh (whosezeal for science, and real goodness of heart, is well known to his friends), I owe the perusal of many books, which I could not otherwise have seen, and which were of great use where the provincial names, of birds especially, wanted to be cleared up ; and that such is the case, will be evident to any one who looks into Sir Robert Sibbald, Martin, and others, who have often multiplied names for the same thing, by taking much from hearsay, and thereby rendered their books much less useful than otherwise they might been to those that followed them.

I owe many kind hints, on particular subjects, to several gentlemen and clergy in Orkney and Shetland, to all whom I pay this public acknowledgment, and hope what follows will encourage every man of curiosity in these isles to throw in his mite, to bring the natural history of the Orkneys as near perfection as possible: and to such I am bold to say, that if they find the study of nature as pleasing as I always did, they will be not only amply rewarded for their trouble, but their minds will be wonderfully satisfied, from thus taking a view of the various works of their great Creator. To all such as study nature in this manner, I wish all success

* Now the Right Hon. Sir Joseph Banks, Bart. P. R. S.-Edit. 



\section{EXPLANATION OF THE CONTRACTED NAMES.}

Lin. Sys. ....... Caroli Linnæi Systema Naturæ, Ed. 12.

Brit. Zool. ....... Pennant's British Zoology, 4 Vol. 4to and 8vo.

Sib. Scot. ....... Prodromus Historia Naturalis Scotix. Auctore Roberto Sibbaldo.

Pen. Syn. Quad. .. A Synopsis of Quadrupeds, by Thomas Pennant, Esq. Raii Syn. Quad. .. Raii Synopsis Methodica Anim. Quad. et Serpentini Generis.

Raii Syn. Av. .... Raii Synopsis Avium et Piscium.

Faun. Suec. ...... Caroli Linnæi Fauna Suecica.

Wil. Orn. ....... The Ornithology of Mr Francis Willoughby.

Mart. West. Isles. .. Description of the Western Isles of Scotland. By M. Martin, Gent.

Wal. Desc. Ork. .. An Account of the Islands of Orkney. By J. Wallace, M. D.

Sib. Hist. Fife. .... History of the Sheriffdoms of Fife and Kinross. By Sir Robert Sibbald.

Ed. Av. ........ Natural Hist. of Birds, \&c. By George Edwards.

Pen. Tour. ...... A Tour through Scotland. By Thomas Pennant, Esq.

Sib. Phal. ...... Phalainologia. Auctore Roberto Sibbaldo. 



\section{CONTENTS.}

\section{CLIASS I.-QUADRUPEDS.}

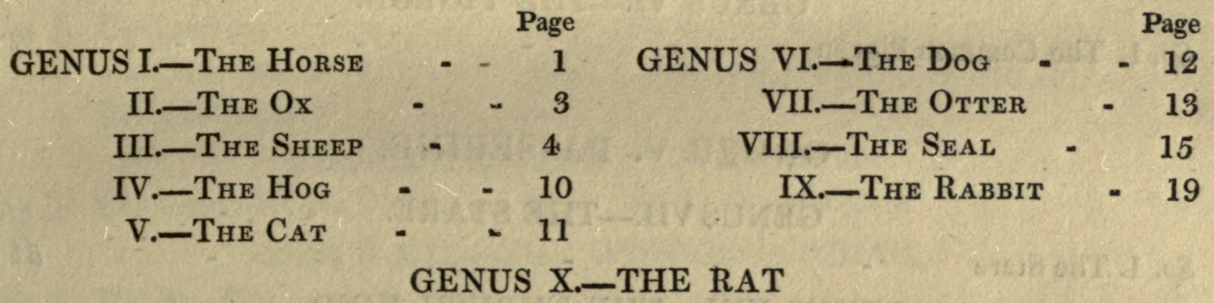

Sp. 1. The Common Black Rat - 21 Sp.4. The Short-tailed Field-Mouse ib.

2. The Norway Rat - " 22

5. The Common Mouse _ _ 26

3. The Field Mouse - $\quad 25$

GENUS XI.-THE SHREW-MOUSE.

Sp. 1. The Shrew-Mouse

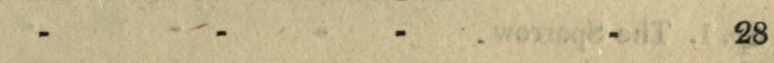

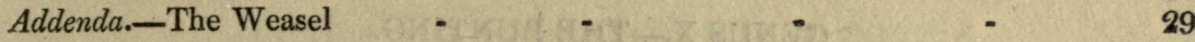

\section{CLASS II -BIRDS.}

ORDER I. RAPACIOUS.

\section{GENUS I.-THE FALCON.}

Sp. 1. Ringtail Eagle $\quad-\quad 31 \quad$ Sp. 6. The Hen-Harrier $\quad$ - $\quad 37$

2. The Sea Eagle _ _ $32 \quad$ 7. The Kestril _ _ _

3. The Erne - - $\quad-34 \quad$ 8. The Sparrow-Hawk - 38

4. The Gyrfalcon _ $\quad$ - $35 \quad$ 9. The Merlin _ - $\quad 39$

5. The Goshawk - $\quad$ - 36

GENUS II.-THE OWL

Sp. 1. The Eagle-Owl - $\quad 41 \quad$ Sp.3. The White Owl - $\quad 44$

2. The Short-Eared Owl - 42 4. The Brown Owl - - ib 
ORDER II. PIES.

GENUS III.-CROWS.

$$
\text { Page }
$$

Sp. 1. The Raven

GENUS IV.-THE CUCKOO.

Sp. 1. The Cuckoo

\section{ORDER III. GALLINACEOUS,}

GENUS V.-THE GROUSE.

$S p .1$. The Grouse

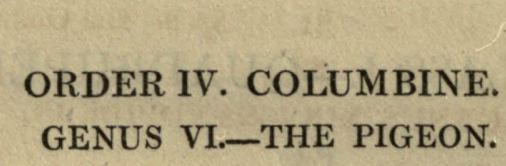

ORDER V. PASSERINE.

GENUS VII.-THE STARE.

Sp. 1. The Stare

$$
\text { GENUS VIII-THE THRUSH KIND. }
$$

Sp. 1. The Fieldfare - - 56

2. The Song-Thrush, or Throstle 57

Sp. 3. The Redwing

4. The Blackbird - $\quad 58$

GENUS IX.-THE GROSBEAK.

Sp. 1. The Sparrow

US IX.-THE GROSBEAK.

GENUS X.-THE BUNTING.

Sp. 1. The Bunting

$60 \quad S p .2$. The Greater Brambling - 61

GENUS XI.-FINCHES.

Sp.1. The Chaffinch - $\quad$ - $62 \quad S p .3$. The Lesser Red-headed Linnet 64

2. The Linnet - - $63 \quad$ 4. The Mountain Linnet, or Twite ib GENUS XII.-THE LARK.

Sp. 1. The Sky-Lark - $\quad-65 \quad$ Sp.2. The Tit-Lark - - 67 GENUS XIII.-WAGTAILS.

$S p$. The White Wagtail

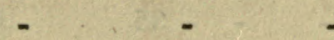

GENUS XIV.-WARBLERS.

Sp. 1. The Redbreast - $\quad 69 \quad 5 p .3$. TheGolden-Crested Wren - 71

2. The Wren - 70 4. TheWheat-Ear - - 72 
GENUS XY.-THE SWALLOW.

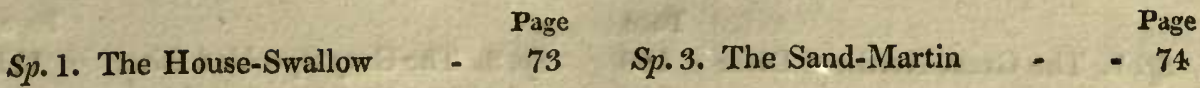

2. The Martin - - 74

ORDER VI. CLOVEN-FOOTED, OR WADERS.

GENUS XVI.-THE HERON.

Sp. 1. The Crested-Heron - 77 Sp. 2. The Ash-Coloured Heron - 78

GENUS XVII.-THE CURLEW.

Sp. 1. The Curlew

GENUS XVIII-WOODCOCKS, OR SNIPE KIND.

Sp. 1. The Snipe - - $\quad$ - $81 \quad$ Sp.3. The Godwit - - 82

2. The Jack-Snipe - $\quad 82$

GENUS XIX.-SANDPIPERS.

$S p .1$. TheLapwing - - $84 \quad S p .4$. The Purre - - 87

2. The Redshank - - $86 \quad$ 5. The Dunlin - - 88

3. The Turnstone - $\quad 87$

GENUS XX.-THE PLOVER KIND.

Sp. 1. The Green-Plover - $\quad 88 \quad S p .2$. The Sea-Lark - $\quad 89$

GENUS XXI.-THE OYSTER-CATCHER.

Sp. 1. The Sea-Pie -

GENUS XXII.-THE RAIL.

Sp.1. The Water-Rail - - - - - - 93

GENUS XXIII-GALINULES, OR WATER-HENS.

Sp. 1. The Land-Rail - $\quad 94 \quad S p .2$. The Water-Hen - - 95

ORDER VII. WITH PINNATED FEET.'

GENUS XXIV.-PHALAROPE.

Sp. 1. The Red Scollop-toed Sandpiper

GENUS XXV.-THE GREBE KIND.

$S p .1$. The White and Dusky Grebe

ORDER VIII. WEB-FOOTED BIRDS.

GENUS XXVII.-THE AUK KIND.

Sp. 1. The Auk - - - $99 \quad$ Sp.3. The Little Auk - - 103

2. The Puffin $-101$

GENUS XXVII.-THE GUILLEMOTE.

Sp. 1. The Guillemote - - 104 Sp.2. The Black Guillemote - 105 
xviii

CONTENTS.

GENUS XXVIII-THE DIVER.

Page

$S p .1$. The Great Northern Diver 108

Sp. 3. The Gray Speckled Diver

Page

2. The Immer

110

4. The Red-throated Diver - 112

GENUS XXIX.-THE GULL KIND.

Sp. 1. Great Black and White Gull 116

2. The Arctic Gull _ $\quad 118$

Sp.5. The Brown and White Gull 122

3. The Skua - - - 119

4. The Herring-Gull _ 122

6. The Common Gull - 123

7. The Tarrock - _ ib

8. The Pewit Gull - - 124

GENUS XXX.-THE TERN.

Sp. 1. The Greater Tern

GENUS XXXI_-PETRELS.

Sp. 1. The Shear-water - $\quad$ - $127 \cdot S p .2$ The Stornfinch - - 130

GENUS XXXII.-THE MERGANSER, OR DIVING-GOOSE.

Sp.1. The Goosander

GENUS XXXIII-DUCKS.

Sp.1. The Wild Swan - - 133 Sp.8. The Mallard - - 140

2. The Goose - - 134 9. The Pintail Duck - $\quad 141$

3. The Bernacle - - $135 \quad$ 10. Swallow-tailed Shieldrake 142

4. The Brent Goose - $136 \quad 11$. The Wigeon - - 143

5 The Eider Duck - $\quad 137 \quad$ 12. The Garganey _ - 144

6. The Tufted Duck - 138 13. The Teal - - - ib

7. The Shieldrake - $139 \quad$ 14. The Golden-Eye - - 145

GENUS XXXIV.-THE PELECAN.

$S p .1$. The Cormorant or Corvorant $146 \quad S p .3$. The Gannet - - 148

2. The Shag - - - 147

Addenda.

The Coot -
The Turnstone

The Peregrine Falcon

\section{CLASS III.-REPTILES.}

GENUS I.-THE FROG.

Sp. 1. The Common Frog - $153 \quad$ Sp.2. The Toad - - 154

CLASS IV.-FISHES.

GENUS I.-CETACEOUS FISH.

Sp.'1. The Common Whale

2. The Round-lipped Whale
157 Sp. 3. The Beaked Whale

158.
149

150

ib 
GENUS II-CACHALOT, OR SPERMACETI WHALES.

Sp. 1. The Great-headed Cachalot 160

Page 162

2. The Round-headed Cachalot 161

GENUS III.-CETACEOUS FISH, WITH TEETH IN BOTH JAWS.

Sp.1. The Porpesse - $\quad 163 \quad$ Sp.2. The Grampus _ - 165 GENUS IV.-THE SKATE, OR RAY.

Sp. 1. The Skate _ - $\quad 167 \quad$ Sp.3. The Thornback _ $\quad 169$

2. The Sharp-nosed Ray - 168

GENUS V.-THE SHARK KIND.

Sp. 1. The Piked Dog-Fish - $170 \quad$ Sp.3. The White Shark - $\quad$ 174

2. The Basking-Shark - $171 \quad$ 4. The Lesser Dog-Fish - 175 GENUS VI.-THE STURGEON.

Sp. 1. The Sturgeon

\section{GENUS VII.-THE LUMP FISH.}

Sp.1. The Lump-Fish $\quad-177 \quad$ Sp.2. The Sea-Snail * - 178 GENUS VIII-THE PIPE-FISH, OR SEA-NEEDLE:

Sp. 1. The Longer Pipe-Fish - 179 . Sp. 3. The Little Pipe-Fish - 182

2. The Shorter Pipe-Fish $\quad$. 181

Addendum.-The Fishing-Frog

GENUS IX.-THE EEL.

Sp. 1. The Common Eel _ $\quad 184 \quad$ Sp.2. The Conger _ _ 186 GENUS X.-THE WOLF-FISH.

Sp. 1. The Sea-Wolf

GENUS XI-THE LAUNCE.

Sp. 1. The Launce

GENUS XII-COD-FISH KIND.

Sp. 1. The Common Cod-Fish - 190

2. The Haddock - - 192

Sp.5. The Whiting - - $\quad 197$

3. The Coal-Fish - - 193

6. The Ling - - - 198

4. The Pollack - $\quad 196$

7. The Whistle-Fish - 199

GENUS XIII.-THE BLENNY.

Sp. 1. The Spotted Blenny - 202 Sp.3. The Viviparous Blenny - 204

2. The Purple Blenny - 203

GENUS XIV.-THE GOBY.

$S p .1$. The Black Goby

GENUS XV.-THE BULL-HEAD KIND.

Sp. 1. The Father-Lasher 205 
GENUS XVI.-THE DOREE.

Page

Sp. The Opah

\section{GENUS XVII.-THE FLOUNDER KIND.}

Sp. 1. The Holibut - - 211

2 The Plaise - $\quad 212$

Sp. 4. The Sole

208

3. The Flounder

- $\quad$ - ib

5. The Turbot

213

GENUS XVIII-THE WRASSE.

Sp. 1. The Wrasse

GENUS XIX.-THE STICKLEBACK.

$S p$. 1. Three Spined Stickleback $216 \quad$ Sp. 2. Fifteen Spined Stickleback 217 GENUS XX.-THE MACKEREL.

Sp. 1. The Mackerel 218 GENUS XXI.-THE SALMON.

Sp. 1. The Salmon - - 220 Sp.4. The Parr - - - 223

2. The Bull Trout - - 222 5. The Char - - 224

$\begin{array}{lll}\text { 3. The Trout - } & \text { 6. The Grayling : - } 223 & \text { - ib }\end{array}$ GENUS XXII-THE ARGENTINE.

Sp. 1. The Argentine - - * $\quad$ - 225

GENUS XXIII.-THE HERRING.

Sp. 1. The Herring

Addenda.-The Gemmeous Dragonet

The Gray Gurnard

The Saury

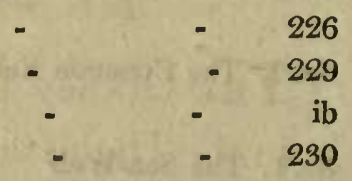




\section{NATURAL HISTORY OF ORKNEY.}

\section{CLASS I.-QUADRUPEDS. \\ GENUS I.-THE HORSE.}

Equus Caballus. Equus cauda undique setosa, Lin. Syst. 100. Brit. Zool. 1 . p. 1. Illust. Tab. 50, for the Arabian. Sibbald, Scot.6.

THE Orkney breed of horses is but small, being that used in the Highland shires of Scotland, such as Caithness, Sutherland, \&c. but, when properly taken care of, are neat, brisk, and hardy; well adapted to the nature of our uneven country ; can bear much more fatigue than the large south-country horses brought hither; and, in a word, serve well every purpose of the farmer. Some time ago the Orkney men had a vast prejudice against keeping mares, and raised none of their own horses, which were all imported, at a vast expence, from the northern shires of Scotland; but within these six or seven years, they seem pretty much to have got over this whim, and every man rears as he can afford, which will save yearly some thousand pounds to the country. The shelties 
mentioned by Buchanan, and described by Sir Robert Sibbald* as no larger than asses, and said to be common both to Orkney and Zetland, are at present confined to the latter, where they still preserve their character of excellent workbeasts : they bring a very few of them to Orkney, but more are sent to other parts of the kingdom, being purchased as curiosities, and to teach children to ride, though their strength is such, that they can carry a man with ease for a long while together. 'The price of Orkney horses is high, considering the country; indeed, I am often surprised how a farmer here can afford 5, 6, 8, or L.10 Sterling for a horse, and purchase the number many of them keep, especially when I reflect on the little profit many of them make of their farms, which, though greater in some parts of the country than others, is by far less than might be, had they proper markets to bring the produce of them to. Asses are scarce ever seen in the Orkneys, and mules, I dare say, never $\uparrow$.

* Equulei, quoque Orcadenses et Schetlandici, asino haud majores, laboris patientissime sunt.

+ In addition to the history of the horse, I shall insert what the writer of the Husbandrie used by the Orchadians says of these in Orkney: "Their horses lieves " on beare calfe, and grows exceeding fat on the same; they be very little, but " quck and fierie." To which Mr M'Kaile adds, with truth, "The horses are "little, and go all barefoot, unless the gentlemen put shoes upon the horses upon " which they ride themselves."-P. 


\section{GENUS II.-THE OX.}

Bos Taurus, Lin. Sys. 98. Sib. Scot. 7. Brit. Zool. 15. Penn. Syn. Quad. 4.

Thrs very useful animal seems to be very little regarded in the Orkneys, and is seldom suffered to live above the third year, which, if considered, is a great loss to the farmer. They are very little in the way of setting them to any work here (except a few gentlemen who use them to the plough); though I should think, according to the nature of the country, which is now very much frequented by shipping, these would be preferable to horses, as, when past working, they are no worse for being fed for beef, of which at present a small quantity is made for the Leith market, and for shipping, though much more might be sent to market, and expended in our own country, were trade, fishing, \&c. carried on to that extent, and with that spirit it ought, and casily might, in a country so well situated for it. Beef in Orkney sells cheap, seldom above three-halfpence per pound, commonly at a penny, or a penny-farthing ; however, it must be confessed, our Orkney beef is neither so large nor so strong as that from the southern countries, nor is it so fit for sea-stock, as it seldom bears salt well for any length of time ; for present use, it is both sweet and well-tasted.

Cows are kept in numbers, on account of the rents of the land, part of which is paid in butter, which is distinguished into what is here called meat and grease-butter. The latter 
is but coarse, but serves many useful purposes in the soapworks, for cart and coach-wheels, grease, laying of sheep, \&c. and, of consequence, is sold high, sometimes at L. 3 odd a barrel, which is more than the best is sold for.

The other articles of merchandize drawn from our cattle, besides beef, of which, one year with another, about a ton may be exported, are hides, tallow, and smoked tongues, which all sell well, and answer our merchants' credit for the few articles required in these parts, and which is entirely confined to those fitted for home consumption.

\section{GENUS III.-THE SHEEP.}

Ovis, Raii Syn. Quad. 73. Ovis Aries, Lin. Sys.97. Penn. Brit. Zool. I. 22. Ejusd. Syn. 10.

IN this description of the domestic animals, I would not be understood to place this, or any of the foregoing, as natives of these islands ; perhaps none of them are, though it is hard to say at what period they have been introduced : all I mean, by giving them a place here, is to shew in what manner our economy depends upon them, and how they are treated with us, compared with the rest of the world.

This most useful animal seems to have been formerly a greater object with the inhabitants of Orkney than it is now. In the Orkney acts, I find many with relation to the manage- 
ment of sheep ; as*, 1st, to ascertain the property; $2 \mathrm{~d}+$, the time of shearing; $3 \mathrm{~d}$, with regard to buying and selling; - none of which particulars were allowed to be transacted in secret, or at the will even of the owners, but all must be done in presence of the bailie, and other public officers of the parish; and this for preventing frauds of every kind, in a subject in which the whole community had a concern. 'To understand this last particular, we must observe, that the sheep in Orkney are never housed at any season, but those of a whole island, parish, \&c. constitute a promiscuous flock, out of the power of the owners, except once a-year, when they are to be rowed, (as it is here called) and the lambs marked. Now, if every man had been indulged with a liberty to make free with such a promiscuous property, it would been tempting to dishonesty, and led the whole country into many inconveniencies ; to remedy which, they had a set of the most sagacious men in every parish or district set apart, whose business it was to take notice that due regard was paid to the regulation made in this case. As the sheep, upon every occasion, must be taken with the help of dogs + , trained for the

* Act " Anent marking of Sheip :-That nane mark sheip, on the mark called " the king's mark, (especiallie within the mainland) without warrand."-Acts in MS. It was also ordered, that every mark should be registered in a book kept for the purpose.

+" Anent rowing of sheip :-That na man row sheip, untill the time they are lawfullie warned be the baylzie, as they will eschew to be repute thieves."-Ib.

$\ddagger$ "Anent Sheip-dogis:-That na man keip sheip-dogis but sic as are chosen " be the sherrifis and baylzies, with consent of the parochines, and for whom the " baylzie shall be answerable, under the pain of ten punds."-Ib. 
[Quadrupeds.

purpose, every man was not allowed to keep these, but, to hinder all dishonesty, only a few were to be named by the parish bailie, and who were to be registered in his books, and for whom this officer was to be answerable; these alone were to keep sheep-dogs, and to these or the bailie must every man apply upon every occasion when his part of the common flock was concerned; at their sight he was to buy, sell, mark, row, or kill ; and, without these precautions, no man durst intermeddle without being habit and repute a thief, and prosecuted accordingly. To ascertain the property, every man was to fix upon some particular mark, which was to be registered in a parish book, and affixed at a certain season of the year, likewise before the bailie, or his* lawright-men ; and the time of rowing was intimated by proclamation, when all were to attend, and in public claim their own.

The breed of sheep in Orkney is but small, and there is now but little care taken for their improvement, all the foregoing regulations being now in disuse. They, as was said before, are never housed, which, with their natural timidity, makes them remarkably wild, and has given a handle to many to assert, that Orkney sheep were hunted like other game. Though this is but in some measure true, yet these mild and gentle animals, which seem particularly adapted by Providence to supply us with the clothing, \&c. we, by nature, so much want-I say, they seem here to be no favourites, but left to every storm, and to perish by every enemy. The

* A sort of assessors to the parish bailie. 
eagles and ravens destroy them, while lambs, in numbers; the storms of winter and the sea, to which they are obliged to fly, in this inclement season, for a meal, kill them in hundreds; but this is nothing but accident, nor equal to the tyranny practised over them by their pretended lord, Man, to whom they owe nothing, even for so much as shelter. He is not content with what they can easily spare, and that without complaint, their yearly tribute; but all their lives are, sooner or later, at his call, and required with the greatest severity. Not even content with this last sacrifice they make him, he (here) uses them with the greatest cruelty, in receiving their offered and grateful price of a little longer liberty. About midsummer there is a particular day published for rowing, when all the men in the parish, attended with their dogs, turn out, and drive the whole flock, without any preparation of washing, into narrow pens, and from thence, I may say, to the place of execution, where the wool is torn (not shorn) off their backs, an operation which brings the whole blood into their skin, and is not only disgusting, but, if the season proves harsh, is the cause of great destruction. But, however cruel it may seem, it is almost the only notice that is taken of these useful animals, by their unfeeling masters, till that time twelvemonth.

This operation is far different from that similar, so beautifully described by Thomson in his Seasons :

Or rushing thence, in one diffusive band,

They drive the troubled flocks, by many a dog

Compell'd, to where the mazy-running brook 
Forms a deep pool; this bank abrupt and high,

And that fair spreading in a pebbled shore.

Urg'd to the giddy brink, much is the toil,

The clamour much, of men, and boys, and dogs,

Ere the soft fearful people to the flood

Commit their woolly sides. And oft the swain,

On some impatient seizing, hurls them in :

Embolden'd then, nor hesitating more,

Fast, fast they plunge, amid the flushing wave,

And, panting, labour to the farthest shore.

Repeated thus, till deep the well wash'd fleece

Has drunk the flood, and from his lively haunt

The trout is banish'd by the sordid stream;

Heavy, and dripping, to the breezy brow

Slow move the harmless race, where, as they spread

Their swelling treasures to the sunny ray,

Inly disturb'd, and wond'ring what this wild

Outrageous tumult means, their loud complaints

The country fill; and, toss'd from rock to rock,

Incessant bleatings run around the hills.

At last of snowy white, the gather'd flocks

Are in the wattled pen innumerous press'd

Head above head; and, rang'd in lusty rows,

The shepherds sit, and whet the sounding shears.

The housewife waits to roll her fleecy stores,

With all her gay dress'd maids attending round.

One chief, in gracious dignity enthron'd,

Shines o'er the rest, the pastoral queen, and rays

Her smiles, sweet beaming, on her shepherd king;

While the glad circle round them yield their souls

To festive mirth, and wit that knows no gall.

Meanwhile, their joyous task goes on apace:

Some mingling stir the melted tar; and some,

Deep on the new shorn vagrant's heaving side, 
To stamp his master's cypher ready stand ;

Others the unwilling wether drag along ;

And, glorying in his might, the sturdy boy

Holds by the twisted horns the indignant ram.

Behold, where bound, and of its robe bereft,

By needy man, that all-depending lord,

How meek, how patient, the mild creature lies!

What softness in its melancholy face,

What dumb complaining innocence appears !

Fear not, ye gentle tribes, 'tis not the knife

Of horrid slaughter that is o'er you wav'd ;

No, 'tis the tender swain's well-guided shears,

Who having now, to pay his annual care,

Borrow'd your fleece, to you a cumb'rous load,

Will send you bounding to your hills again.

Thomson's Summer.

I hope the beauty of this description, and the contrast it makes with the former, with respect to the management of wool, this so useful commodity, and the method of procuring it in such a manner as to be least hurtful to the creature that gives it, will excuse the length of it. The Orkney sheep are very prolific, many of them bringing two lambs, some three, but twins are common. The mutton is here in general but ordinary, owing to the sheep feeding much on seaware, to procure which these creatures shew a wonderful sagacity ; for no sooner has the tide of ebb begun to run, but they, though at a great distance, immediately betake themselves full speed, one and all, to the shore, where they continue till it begins to flow, when they as regularly retire. The 
wool of the Orkney sheep is short, but fine, insomuch that stockings made of some of it, and often washed, become like a sort of felt. It is manufactured into coarse cloth, stuffs, coarse and very fine stockings, of all which small quantities are exported, or consumed amongst ourselves.

The goat should come next, but this has yet been so sparingly introduced, as scarcely to claim a place in our Orkney Fauna.

\section{GENUS IV.-THE HOG.}

Raii Syn. 92. Sus Scrofa, Lin. Sys. 102. Brit. Zool.40. Pen. Syn. 68. Sib. Scot. 9.

OURs is a variety of the common, of a very small size, and variable colour, the back full of very large and long bristles, the ears erect and sharp pointed, the nose surprisingly strong: in a word, their appearance is altogether different from those brought from the south, as their size is remarkably less. They commonly go through the hills, feeding on the roots of plants, earthworms, or what else they can pick up. When admitted among the corn grounds, they make vast havock by rooting; seem to be much more mischievous in this way than the largest English breed, seldom leaving till they throw up a ditch large enough to bury half a dozen of them, which standing full of water all winter, does vast hurt to the grounds, though our farmers stiffy maintain the contrary. 
When killed from the mountains they make but ordinary meat, and yet they are seldom otherwise fed; when properly managed they make very good pork and ham, and are sold in quantities to the shipping, either in this manner, or quite fresh from the knife.

An Orkney swine seldom. weighs above sixty or seventy pounds, and this sold to the stranger at twopence per pound; however, the country people seldom receive from the butcher above four or five shillings Sterling a head; oftener under than above.

Of the hair they make (notwithstanding its shortness) those ropes with which they let one another over the steepest and highest rocks, in quest of wild-fowl and their eggs; and they tell us (with what truth I know not) they answer much better, and are less ready to gall on the rugged rocks, than the best hempen ones. However this may be, many of them are lost in these dreadful attempts, few of their professed climbers living out their days.

\section{GENUS V.-THE CAT.}

Felis Domestica seu Catus, Raii Syn. 170. Felis Catus, Lin. Sys.62. Brit. zool.45. Pen.Syn. 183.

REMARKABLE for nothing here, more than elsewhere, except the many apocryphal stories told of its not being able 
to live in some of our islands. 'These are faithfully propagated, and handed down from father to son ; however, none of the stiffest assertors of the story could assure me they had made the experiment. This story is gravely told of Græmsey, Damsey, and others; but upon asking my informers how they came to know this particular virtue of their islands? They had it from such an old man, who, I suppose, had it from them that should know! The mystery is, there are no mice in these small isles, and, of consequence, no need of cats.

The cats are very ready to run wild, especially when near rabbit warrens, where they make great destruction, being an unsuspected enemy, playing this hour, and killing the next. There have been numerous instances of cats regularly bringing in their prey to their owners; however, they are not always so exact in this particular, but often betake themselves to their own shifts, when once they have tasted the sweetness of the cuning's blood.

\section{GENUS VI.-THE DOG.}

Canis, Raii Syn. Quad. 175. Canis Familiaris, Lin. Sys. 56. Brit. Zool.49. Pen. Syn. 141.\& 144. Sib. Scot. Ill. 12.

THFRE are several varieties of the dog kind to be found here, as elsewhere, trained for different purposes, as the water 
and land spaniels, for fowling, and curs for giving warning by barking ; but the most common are the shepherd's dog, and mongrels from it, called in general collys, or sheep-dogs. These are trained up to a sport, which, (says Mr Wallace) is " both strange and delectable," namely, hunting of sheep. The master of the dog has him in his arms, and points out the sheep, which he very nimbly seizes from all the flock, and, without much hurt, detains it till released by his master*. This custom had its inconveniencies, and oft times it happened, as it does still, that the dog which could seize a sheep for his master, could do the same for himself. To prevent this, in the country acts, it was statute $\uparrow$ : " That nae man " shall keep running dogis, that runs frae house to house, " or through the country, cheasing their neighbours sheip ;" and this under the highest penalties.

Foxes or wolves, I dare say, never had a footing in Orkney.

\section{GENUS VII.-THE OTTER.}

Loutra. The Otter, Raii Syn. Quad. 187 Sib. Scot. 10. Mustela Lutra, Lyn. Sys. 66. Brit. Zool.67. Pen. Syn. 238.

OTTERS are found very frequent in these islands, burrowing in the banks of the sea, as well as those of the fresh-wa-

* See the article Sheep.

+ Country Acts, MS. 
ter lakes. I was lately informed of a pair who made a drain under a house in Kirkwall their haunt. They live upon collfish, conger-eel, or other fish in the sea, and trout in the fresh waters ; are very delicate ; eat only the best parts of the fish, leaving the rest to be picked up by the country people. They always shut their eyes while eating; are often then surprised and killed. A young gentleman in the neighbourhood lately told me, he observed one on a sea rock at his meal, upon which he walked straight up to him, and, with a blow of a cudgel, so stunned him, that he put a strong rope about his neck, and led him home. Another man, who had wounded one with small shot, was not so lucky, for, on his appearing to be lifeless, he threw him over his shoulder to carry him home ; he had not gone far before the animal recovered, and, before he was aware, bit him most severely. Indeed, their bite is always very hard. I was informed of a struggle between a wounded one, and a strong water-spaniel, in the water : upon the latter's seizing him to drag him ashore, he fastened on the spaniel's leg, and in a moment snapt the bone to pieces.

The otter's skin is an article of our exports, and when killed in winter is valuable; however, I am told by many they are much scarcer than formerly. Skins sell here for about six shillings a-piece, if in season*.

I have seen those killed in the sea, as well as fresh-water

* In Shetland they are very plentiful, and valuable. They transport the fur to Hamburgh, and sell them from six to twelve shillings a-piece. 
lakes, but can observe no difference, notwithstanding Linnæus tells us they never are seen in the sea.

\section{GENUS VIII.-THE SEAL.}

SEA L.-Gen. Char. Cutting teeth, and two canine teeth in each jaw ; five palmated toes on each foot; body thick at the shoulders, tapering towards the tail.

\section{The Common Seal.}

Seal, Seoile, or Sea-Calf; Phdca, seu Vitulus Marinus, Raii Syn. Quad. 189. Sea-Calf, Philos. Trans. No. 469.tab. 1. Phoca Vitulina, Lin. Sys. 56. Pen. Brit. Zool. 71. Ejusd. Syn. 339. Orc. Selch, or Selchy.

Seals with us are very numerous, especially in the desert isles, or sea rocks, that are separated from the land; here they lie, while the sea is low, in droves, and in season bring forth their young. Not having a specimen before me, I shall give that of my honoured friend Mr Pennant, as published in his works, to which, and his correspondence upon any difficulty, I have been often and much obliged, and think myself happy in having it in my power to return him, in this manner, my most grateful acknowledgments, for the countenance he has all along shewn me in the prosecution of this work, and ever since I had the honour to be known to him. "The head and nose broad and flat, like those of the otter ; 
[Quadrupeds.

" the neck short and thick; the éyes large and black; tongue " forked at the end; nostrils oblong; on each side the nose "6 were several long stiff hairs (these in the specimens I have "seen are undulated); and above each eye were a few of the " same kind ; two canine teeth in each jaw ; six cutting teeth " in the upper jaw, four in the lower ; no external ears ; body " covered with hair; short tail ; toes furnished with strong and " sharp claws ; colour varjous, dusky, sand-coloured, brinded, " spotted with white or yellow; the hair of the old ones is "thick, short, and glossy ; that of the young, long, white, and "woolly."

The largest seal I ever saw in Orkney measured, from the point of the nose to the hinder claws, eight feet.

The seal swims with vast rapidity, and before a gale of wind is full of frolic, jumping and tumbling about,sometimes wholly throwing itself above water, performing many awkward gambols, and at last retiring to its wonted rock, or cavern, which it keeps possession of (if undisturbed by man), from its own species (I have seen them often pushing one another down), and there continues till the storm is over. Seals seem to have a great deal of curiosity : if people are passing in boats, they often come quite close up to the boat, and stare at them, following for a long time together; if people are speaking loud, they seem to wonder what may be the matter. 'The church

- of Hoy, in Orkney, is situated near a small sandy bay, much frequented by these creatures; and I observed when the bell rung for divine service, all the seals within hearing swam directly for the shore, and kept looking about them, as if sur- 
prised, rather than frighted; and in this manner continued to wonder, as long as the bell rung.

Numbers of seals are yearly caught about our coasts, both with nets and shot, for the sake chiefly of the skins and oil, though I am credibly informed, in North Ronaldsha they take them for another purpose, namely, for eating; and they say they make good ham. I have seen numbers of them cut up, and have no doubt but the young ones may eat tolerably well, but the large and old ones must be very ordinary feeding, because the flesh is both black and very coarse-grained.

There is a ship commonly goes from this place once a-year to Soliskerry, and seldom returns without 200 or 300 seals. She is manned with between thirty and forty men, who, as soon as they come up with the rock, land (except a few left to keep the ship, and receive what the others kill), and immediately surround what seals are then on it. One party armed with clubs, fall to knocking them on the head, and another set to jacking, i.e. cutting off the skin, together with the blubber on it, while the others put it on board. They continue thus as long as they have any thing to do, and, when all is over, immediately set sail, otherwise they are in danger from the weather; if it blows up there is no such thing as getting into their boats. When they arrive the jacks are divided, and sold by public auction, at about five or six shillings sterling a.piece; and each man makes about thirty shillings sterling for his share, after allowing a third for the vessel, and something more than a common share for the master. After all is disposed of, the blubber is cut from the skin, and boil- 
ed into oil, which sells well, and with profit to the merchant. The skins are pinned to the walls of houses till dry, and are then sold to the trunkmakers and others, for eightpence or one shilling a-piece, small and great.

The young and smaller seals yield the most oil ; the largest are good for little, except the skin; indeed, our seal-catchers seldom care for killing the old ones, where they can have the others.

Our tanners dress the seal's skin both for shoes and breeches, but they do not answer very well for the former, being soft and spongy; when properly managed do well for breeches. They are likewise dressed with the hair on, for saddle-covers, and I have seen very beautiful ones made into waistcoats.

Seals seem to be subject to a plague, or murrain. About four years ago they drove ashore round our coasts in scores ; likewise in Caithness many of them were found dead. They were observed to cough much, make a sort of plaintive noise, and when they died and drove ashore were much swelled, and appeared as if very fat, but when cut up were nothing but skin and bone.

The places where seals abound most in Orkney are, the Skerries of Hoy, North Ronaldsha, and others of the north isles; the Barrel of Butter, Pightland Skerries, and several other holms of the south division of the islands; but they are to be found round all the flatter coasts, and the caverns of the sea. 
The Rabbit.]

OF ORKNEY.

\section{GENUS IX.-THE RABBIT.}

Gen. Char.-Two cutting teeth in each jaw ; long ears; a short tail ; five toes before, four behind.

Cuniculus, the Rabbit or Cony, Raii Syn. Quad. 205. Lepus Cuniculus, Lin. Sys. 77. Sib. Scot. 11. Pen. Brit.Zool. I.90. IV. 41.pl.47. fig.2. Ejusd. Syn. Quad.251. Orc. Cuning.

Many of the islands of Orkney swarm with rabbits. Their skins make a considerable article in trade; are very profitable to the proprietors of sandy grounds on this account, and their flesh ; though I am afraid, upon calculation, it would be found the mischief they do, both in corn and grass grounds, by boring and subjecting them to blowing, is not counterbalanced by the profits of the warrens; but it often happens that present advantage makes us overlook future inconvenience. The rabbits here are all of a brownish gray ; it sometimes happens, though seldom, a white one is seen; but the former is the prevailing colour, with the belly lighter. Those that keep constantly in the mountains are in winter hoary. At this season the fur is most valuable, and each skin is sold here for fourpence or fivepence, but when brought to a proper market will fetch sixpence.

The rabbit is very prolific, breeds many times a-year, and indeed, except in the dead of winter, we seldom see them 
without young ones. They are but tender, and sometimes sink under our winters*; a long snow either smothers or starves them in their holes; but a season recruits them, and they swarm as much as ever.

When confined to their holes by storm, live on the roots of grass, which they dig through the sand in search of; are sometimes forced to the farmers' yards in quest of food; and I have seen, in this rigorous season, the leaves of the water-flag pared as far as the frost would allow by them, which at no other season they meddle with. They are often forced down to the sea to feed on the ware, which, in very hard seasons, gives their flesh a bad taste, and often kills them.

The rabbit is a poor defenceless creature, and had not nature furnished it with strong muscular limbs, and a vast inclination to burrowing, would be open to the attacks of every enemy; as it seems to have less swiftness or cunning than the hare, and but little strength to defend itself, even

$\bar{f}$ from the most inconsiderable of the beasts or birds of prey. Its ordinary enemies are the eagles, hawks, ravens, and even hooded-crows and owls, among the birds; otters (as I am credibly informed), dogs, and, to my knowledge, none more mischievous among them than the domestic cats, an unsuspected enemy amongst an unsuspecting (of them at least) people ; besides, the nany inventions of men, such as snares, nets, guns, \&c. all pointed at the life of this poor animal, who

* Which are none of the most severe,-Vide $\mathbf{C}$. of the Climate. 
passes its life in a continual uneasiness, and seldom enjoys an undisturbed hour.

Sir Robert Sibbald, p. 11. Scot. Illus. P. II. gives us a white hare. "In Orcadibus (says he), reperitur crinibus cando" rem nivalem referentibus." Whether there was surh an animal found here when Sir Robert wrote, I know not, but there is none such now, nor is there a hare of any kind to be found in the Orkneys*.

\section{GENUS X.-THE RAT.}

Gen. Char - Two cutting teeth in each jaw; four toes before, five behind; very slender taper tail, naked, or very slightly haired.

\section{Species 1.-The Common Black Rat.}

Mus Domesticus Major, seu Rattus, Raii Syn. Quad. 217. Mus Rattus, Lin. Sys. 83. Brit. Zool.97. Pen. Syn.299。 Sib. Scot. 12.

Whether this is a native of the Orkneys, or when introduced, is more than $I$ know ; this far is certain, that it was

* Torfaus says (p. 136.), there were hares (lepores) in Orkney, and that the hunting of them was the amusement of the Counts; but whether we are to understand by this term rabbits, $\mathbf{I}$ am uncertain, as he uses a word for deer in another place, (p. 140), which is now commonly put for the rein-deer, an animal 
found many years ago much more common than now, having been extirpated by a still more pernicious species, which shall be next described.

The common rat is still to be found in South Ronaldsha, where the other has not come, and, like all the genus, is destructive to every thing eatable, and scarce possible to be excluded.

The story, which Sir Robert Sibbald tells us from Cicero, of their leaving a house before it falls, is here very prevalent; numbers of instances given, as usual in such cases; and great expressions of wonder, if the fact be questioned! Whatever is in this, it is certain rats entirely quit particular houses, and that for years, without any apparent reason, as I have often had occasion to observe, though the catastrophe did not always fulfil the prediction!

\section{Species 2.-The Norway Rat.}

Brit. Zool. 99. Pen. Syn. 300. Brown Rat.

\section{A very large and mischievous species; no native, but in-}

probably never a native of Great Britain. "Consueverant Comites in Catane"siam, indequi ad montana ad venatum caprearum rangiferorumque quotannis "proficissi," \&c.-Vide Torf. His. Rer. Orc. cap. 36.

In an extract made from M'Kailes's Short Relation of the most Remarkable Things in Orkney, I find the following observation: "There are no foxes nor " hares; only $\mathbf{I}$ was informed that, - about eighty years ago, there were several " either black or white hares upon the two great mountains of Choye," \&c.-P. 
troduced by shipping; swarms in the mainland of Orkney; suffers none else of the genus to remain where it comes. It infests our houses, barns, and storehouses. Our hen-roosts, and rabbit-warrens, are not safe for it. Even man himself, whether alive or dead, can scarce be preserved fiom the attacks of this dangerous enemy. The Norway rat is furnished with a set of weapons which render it formidable to creatures which have much more strength; strong legs and sharp claws, which enable it to pierce even walls ; fore-teeth, and muscles of such strength, as nothing but the hardest metals and the solid rocks can resist; an inch plank is no stop to it; it makes its way through the thickest woodwork in a few hours. No place is safe from them, even the church-yards * and the graves of the dead are broke up by this dreadful intruder. This species has got such root in the burying-ground of Stromness, that there is no such thing as extirpating them; the quays of Stromness are full of them; and in houses every thing eatable is devoured or spoiled by them. A lady some time ago told a story of her having put by in a cask, seven hams of our Orkney swine, and some time after, having occasion to use some part of them, found a hole in the cask, and every one of them picked to the bone, with the skin left to

* This calls to my mind a passage in Keysler's Travels, where he tells us, "that " the bones of dead bodies are a real preservative against several species of ver" $\mathrm{min}$; and possibly the earth of a church-yard, where great numbers of corpses " are mouldered away, may be effectual against rats." The church-yard of Stromness is, however, a positive exception to this, for there they swarm without any hope of getting them rooted out.-Vide Keys. Travels, vol, i.p. 91. 
[Quadrupeds.

cover it, no further damaged than to afford a passage for them ; nay, there have been instances of childrens toes being gnawn by these animals.

This species swims well, and dives with ease, and long; is very impudent; makes no great haste in withdrawing itself. I have often seen them, when pursued to their holes, turn in the entry, and with a threatening look dare their adversary, scarce disappearing till he comes close up to them.

A few of the islands of Orkney are not infected, I may say, with these animals; but I think they seem to be on the increase, and spread like a plague.

Some of this species are very large. I have measured several of them, which I found differed a little, but the largest, from the nose to the point of the tail, eighteen inches and three-quarters long; the teeth large, strong, and sharp; the muscles of the cheeks very full; the fur brown, lighter below; the tail is almost bare of hair, covered with scales, and in many full of knobs and scars, the consequence of its encounters with cats and other enemies. The ears are large and thin, capable of being much erected, which the animal always does to the utmost when looking earnestly at any thing; the eyes full, black, and somewhat prominent. 


\section{Species 3.-The Field-Mouse.}

Mus Domesticus Medius, Raii Syn. Quad.218. Mus Sylvaticus, Lin. Sys.84. Brit. Zool. 103. Pen. Syn. 302.

Found pretty common in the fields, burrowing in holes of the earth. It lays up a small heap of grain for winter provision ; is sometimes dispossessed of its apartment by the larger earthing field-bee, which, it seems, is not so capable to form for itself a convenient habitation, and therefore shifts the best way it can, by thus forcing a sheltering place.

\section{Species 4.-The Short-tailed Field-Mouse.}

Raii Syn. Quad.218. Mus Agrestis, Faun. Suec. 30. Brit.Zool. 104. Ork. Vole. Mouse.

Tris species is found very common in the mossy and foggy heaths, where it makes itself tracks of several miles long (if they are forthright), over the whole heath. These tracks are about three inches broad, much worn by continual treading, and warped through a thousand directions. Where the fog is short they are open, but where this is long, by it arched above ; seldom turn off for a stone, but, turning half round it, proceed in their former course. 


\section{Species 5.-The Common Mouse.}

Mus Domesticus Vulgaris seu Minor, Raii Syn. Quad. 218. Mus Musculus, Lin. Sys. 83. Brit. Zool. 105. Sib. Scot. 12.

Common everywhere, except in a few of the lesser islands, which our country sages tell us gravely are privileged, and neither cat nor mouse will live in them, even though brought thither. They add further, the earth of these isles brought thence kills them wherever they are. When an honest grayheaded man told me this, I desired to let me have a little of the earth of his isle, to make the experiment, but this he would by no means grant ; this would, in his opinion, take away the virtue from the rest, and of consequence subject them to the common fate of the rest of Orkney. However, I suppose this earth is something a-piece with that of the monastic earth Mr Pennant speaks of in his 'Tour*; perhaps requires some ceremonies we are unacquainted with to make it succeed. .

This is not the only vulgar error the Orcadians have fallen into; they stoutly affirm that, in a wet cold season, all their bear shoots up in the form of wild oatst, and few of them will be convinced to the contrary. They add, that if the next spring prove mild, if again sown, it will put on the appearance of barley! That wild oats do spring in greater quanti-

* Vide Tour through Scotland, p. 158.

+ Vide Stillingfleet's Tracts, where he tells us very much the same thing of his countrymen. 
ties in some years than others, is incontestible, and that in places where bear has been sown, but this is no reason to conclude the bear to be changed into it. It is certain that some seeds will keep their vegetative powers for a number of years; might it not then be supposed that the wild oats which come up in a cold season have been dormant, and such a season not permitting the bear to come up, they being more hardy have succeeded in its place. This, I should think, a more natural way of arguing, and hinders us from being obliged to have recourse to miracles, where there is no need of any.

Perhaps there are some who may think these observations trivial, perhaps they are so, but if they do nothing else they shew the simplicity of the manners amongst us, and into what absurdities human nature will run, when not more or less enlightened by philosophy.

I have seen in Orkney a mouse skin prettily mottled with white and dusky, but never any entirely white*.

* Since writing the above, I received from a neighbouring clergyman an entirely white nouse, which was caught in summer in a stable. 


\section{GENUS XI.-THE SHREW-MOUSE.}

Gen. Char.-Two cutting-teeth in each jaw, pointing forward; long slender nose: small ears; five toes on each foot.

\section{Species 1.-The Shrew-Mouse.}

Mus Araneus, Shrew, Shrew-Mouse, or Hardy Shrew, Raii Syn. Quuad. 233. Sorex Araneus, Lin. Sys. 74. Brit. Zool. 112. Pen. Syn. Quad. 307. Sib. Scot. Mus Araneus, Erd Shrew.

Found but rarely in Orkney. I have only seen two specimens, and these dead ones, which $I$ observed in the fields. The snout small and extended, with many small teeth; the eyes and ears scarce visible; the colour of the fur reddish; the tail shorter than the body; the legs very short.

Labours under a very bad character here, as well as eselwhere; believed to hurt cattle by its breath and bite, but perhaps with little truth; the smell of it is very disagreeable, and on that account it is avoided by almost every creature; cats indeed, mistaking it perhaps for the common mouse, will kill it, but will not eat it.

This creature completes the number of Orkney quadrupeds which have yet been discovered, unless, with Linnæus, we take into this class the cetaceous fishes; which, indeed, have this in common with them, that they breathe through lungs, 
suckle their young, and perform several other functions in common with quadrupeds; but though they are the link of the great chain that connects the quadrupeds with the fishes, yet the chain, in the opinion of many eminent men, ought here to be divided, and the cetaceous fishes placed at the head of these animals in whose more peculiar dominions nature has placed them. Therefore, to follow the great Mr Ray's arrangement, and after the example of my worthy and learned friend Mr Pennant, I shall place them at the head of the inhabitants of the waters, and here close my account of the four-footed race.

\section{ADDENDA.}

\section{The Weasel.}

The Weasel, or Weesel, Raii Syn. Quad. 195. The Whitred, Sib. Scot. 11. Brit. Zool. 82.

TH Is species was introduced into Shetland some years ago, and seems to increase: tradition says by a falconer, who had been denied his hawk-hens, and, in revenge, brought some weasels with him next year, to destroy their domestic fowls. However, this has not answered the end ; nay, they are even of use in keeping off rats and mice, and encouraged for that purpose. 



\section{CLASS II.-BIRDS.}

\section{ORDER I. OR RAPACIOUS. \\ GENUS I.-THE FALCON.}

Gen. Char.-Bill hooked, covered at the base with a naked membrane, or cere; nostrils small, oval, placed in the cere; tongue large, fleshy, and often cleft at the end ; head and neck covered with feathers; legs and feet scaly; middle toe connected from its first joint to that of the outmost by a strong membrane; claws large, much hooked, and very sharp; that of the outmost toe the least.

\section{Species 1.-Ringtail Eagle.*}

Golden Eagle, with a white ring about its tail, Wil. Orn.59. Raii Syn. Av. 6. White-tailed Eagle, Edw. 1. Fal. Fulvus, Lin. Sys. Ringtal Eagle, Brit. Zool.8o. Vol. I.p. 124.

THE great characters which distinguish this from other species of eagles are, a large broad band of white which encompasses the root of the tail ; the legs, which are feathered

- In Orkney all Eagles are called Earnes. 
to the very feet; and in some (which perhaps may be young birds), the head is hoary. It is of a large size, and very frequent in the hills, where it makes its nest in the rocks, which is often placed within reach, and, when this is the case, always becomes a prey to destruction. These birds are very strong, and make vast havock (in breeding-time especially) among lambs, young and old swine, which they often destroy in the mountains, rabbits and poultry. A clergyman some time ago told me, he met with one of them mounted in the air, with a pretty large pig in her talons, which she dropt alive upon his firing at her. We have even a tradition here of an eagle's having taken up a child from behind some reapers, in the parish of Orphir, and carried it to her nest in Hoy; but by the assiduity of the people, who immediately followed her, the child was rescued unhurt*.

\section{Species 2.-The Sea Eagle.}

Sib. Hist. Scot. 14. Sea Eagle, or Osprey, Wil. Orn. 59. Raii Syn. Av. 7. Mart. Hist. West. Isles, 70. The Sea Eagle, Brit. Zool. II. 126. Falco Ossifragus, Lin. Sys. 124.

This very large species is very often seen, and sometimes surprised on our low shores, feeding on fish, which it has either

* Vide Sir Robert Sibbald Scot. 1ll. where the same story is told, though in somewhat a different manner. 
caught itself, or has been left by the otter. I have often seen it soaring, at a vast height in the air, immediately over a conger or other fish, which has by any accident been left dry by the tide; and this may shew us the vast strength of this creature's sight, which can take in such a small object at such a great distance.

The characters which distinguish this species from the last are the legs, which are not feathered to the toes, (as in the last) but only a little below the knees, and the want of the band of white on its tail ; likewise its haunts are more about the sea.

Eagles of every kind (because of their rapacious manners, and the harm they did to the inhabitants in destroying their cattle), were in Orkney proscribed. In the old acts of the country I find the following : "Anent slaying of the earne. " Apud Kirkwal, decimo die Decembris, anno 1625. The " qlk day it is statute and ordained be Thomas Buchannan, "s sheriff-deput of Orkney, with consent of the gentlemen and " suiters of court, being put for the tyme, yt whatsoever per" sone or persones shall slay the earne or eagle, shall have of "6 the bailzie of the parochine, qr it shall happen him to slay "6 the earne or eagle, viiid.*, for every rick within the paro" chine, except of the cottars who has not sheip; and xxs. $\uparrow$ "6 to ilk persone for ilk earne's nest it shall happen him to

* Eightpence Scots, equal to $\frac{8}{8} \mathrm{~d}$. sterling, then the price of a hen in Orkney.

+ Twenty shillings, equal to one shilling and eightpence sterling, then the price of a sheep. 
" herrie; and they all put the same to the bailzie, and the " bailzie shall be holden to present the head of the said earne " at the head court."

\section{Species 3.-The Erne.}

Pygargus, or White-tailed Eagle, Wil. Orn. 61. Raii Syn. Av. 7. Pygargus Hihnularius, an Erne, Sib. Scot. 14. Vultur Albiulla, Lin. Sys. 123. The Erne, Brit. Zool. I. 131. tab.s.

Turs species I only lately discovered in the Orkneys, though it is resident in them, and brings forth its young there. The description is as follows: Bill yellow, long, and crooked at the point, the upper chap falling much over the lower; the cere yellow ; the head, neck, and shoulders ash-coloured, or rather inclining to gray; where the throat and breast are joined, the gray is variegated with several blackish-brown blotches; the belly dark-coloured; the feet a bright yellow, unfeathered, with strong claws; the back and wings almost black, especially the quill-feathers of the latter; the wings themselves very strong and long; the rump of the cock very dark-coloured; the tail, especially in the male, of a very pure white. A pair of these birds build their nests in the BlackCraig of Stromness, and I am told have done so these many years, none* else of the kind offering to disturb that spot, which these have chosen for their retreat.

* This is an old observation, that the eagles maintain their right to that spot 
Sir Robert Sibbald takes notice of another, which he calls the melanætos, and tells us it is found in " una Orcadum in" sularum ;" however, I never could get any account of it, or ever observed it in Orkney.

\section{Species 4.-The Gyrfalcon.}

Jerfalcon, Wil. Orn. 78. Gyrfalco, Ruii Syn. Av.13. Sib. Scot. 14. Brit. Zool. II.p. 135. tab. 4.

Trrs aquiline species I have had an opportunity to see here, but whether a constant inhabitant in Orkney or not, I am not certain, but rather think not.

where they have affixed on for their royal ærie, and is beautifully described by Thomson in his Spring, as follows:-

High from the summit of a craggy cliff,

Hung o'er the deep, such as amazing frowns

On utmost Kilda's shore, whose lonely race

Resign the setting sun to Indian worlds,

The royal eagle draws his vigorous young,

Strong pounc'd, and ardent with paternal fire.

Now fit to raise a kingdom of their own,

He drives them from his fort, the tow'ring seat,

For ages, of his empire; which, in peace,

Unstain'd he holds, while many a league to sea

He wings his course, and preys in distant isles.

Spring, l. 752-768. 


\section{Species 5.-The Gosharvk.}

Sib Scot. 15. Accipiter Palumbarius, the Goshawk, Mas Decitur, the Tercel, Wil. Orn. 85. Raii Syn. Av. 18. Falco Palumbarius, Lin. Sys. 130. Brit. zool. I.p. 140.tab. 5 .

Thrs species is pretty frequent in Orkney, and I suppose is one of the hawks the king's falconer was wont to fetch from our rocks. To this day there is a rent-charge exacted from many of the inhabitants for the maintenance of these hawks, called hawk-hens, and which is still yearly uplifted. Of old it consisted of any carrion, such as a dog, horse, or other garbage, for which they were charged at a stated price if not delivered. Mr Wallace tells us, the kite, or glead, was to be found in Orkney in plenty; however, I never saw nor heard of them, and rather believe those he had seen were stragglers from other countries, for the manner of their flight renders them very conspicuous even at a great distance, so that one can scarce be mistaken in them. But I rather think this species is not to be found in Orkney, as there is no proper shelter for them, they being fonder of gloomy woods than sea-beat rocks, and delighting more in an extensive country than narrow isles; at least these are the observations I made on them while in Scotland, where I seldom observed them very near the sea. 
Species 6.-The Hen-Harrier.

Wil. Orn. 70. Raii Syn. Av. 17. The Hen-Harrier, the male; the Ringtail, the female, Brit. Zool. II. p. 147. Qrc. Kattabelly.

Turs large species is very frequent with us all the year, and approaches nearest the country-houses of any hawk we have, making great destruction among young poultry. Its ordinary flight is lower than the generality of our hawks, and its whole appearance liker the owl kind. In winter is almost white, except the tips of the wings ; in summer more ash-coloured.

\section{Species 7.-The Kestril.}

The Kestril, Stannel, Stanegal, Windhover, Wil. Orn.84. Raii Syn. Av. 16. Brit. Zool. 149. Orc. Windcuffer.

ThIs species is often observed, as it were, rivetted to one place, always attentive to what passes immediately below it, and by this circumstance has gained the name of windcuffers. I lately observed a couple of these which had nested in the steeple of the church of Stenness, in Orkney, and lived in good neighbourhood with a pair of ravens, which likewise had made this their retreat. It preys upon mice, small birds, and some- 
times chickens, which it darts from the air upon, and snatches in an instant, seldom missing its prey.

\section{Species 8.-The Sparrow-Hawk.}

Wil. Orn. 86. Raii Syn. Av. 18. Falco Nisus, Lin. Sys. 130. Brit. Zool. 151. Sib. Scot. 15.

Thrs little mischievous species is found very common in our sea-rocks, as well as in the precipices of the hills, where it defends its nest with great spirit against all intruders. I lately saw a battle between one of this species and the short-eared owl, which began by the latter approaching too near the hawk's dominions. The hawk had visibly the better, notwithstanding the superior bulk of the other; every stroke he gave the owl made him scream out, while he nimbly avoided all harm from his clumsier enemy, and who in the end was obliged to withdraw, and leave him the calm possession of what they fought for.

This species, as well as the next, makes vast havock among pigeons; I have observed it light among a flock, and drive them all several ways, seldom missing one or other of them. It, too, makes great destruction among the smaller birds, coursing them through the air like a little hound, and, how soon it gets a proper opportunity, one stroke finishes the contest; but this is so severe, that a gentleman told me he observed one of this species knock down one of his pigeons, 
which he picked up, and found the entrails drove out of it by the force of the blow.

It is wonderful to observe at what a distance the small birds know this hawk, and with what anxiety they shun him ; when pursued often running themselves into more certain danger; bushes, caves, houses, even the bosom of their general enemy, Man, is then an asylum, though often trying to save their lives, they more certainly lose them.

\section{Species 9.-The Merlin.}

Wil. Orn. 85. Raii Syn. Av. 15. Brit. Zool. 153. Sib. Scot. 15. Merlin, the fenale; Jack, the male. Accipiter Æsalon.

OFTEN seen skimming along the fields in search of prey; flies low ; and, like the former, kills its prey with a stroke of its wing, and sometimes nimbly whips a small bird from the ground, and immediately makes off with it ; remarkably tenacious of its prey, seldom willing to part with it ; to preserve it will catch it in its claws, and fly as well as it can, even though with a pigeon, moorfowl, or other bird heavier than itself. All the merlin's motions are quick, its turnings and windings so much so, that they can scarce be followed with the eye. It is full of spirit; when wounded (if not mortally), fights with bill and claws, and if it hits seldom fails to fetch the blood. In a word, though among the least, it is the briskest among the hawk kind in these islands. 
I have observed in winter a hawk of the bulk of one of the two latter-species, and having very much of their inanners, but different in colour, being ash-coloured above* and white below, but whether one of them having the colour changed by the season I know not, as I never could procure a specimen.

When falconry was in vogue, the Orkney hawks were in much esteem and request, and a falconer came once a-year to carry off the young birds ; but what species it was he sought after I cannot get any tolerable information, as the names are delivered in such general terms there is no drawing any thing from. I hear of the falcon, the tercel, and the hawk, but what species of these I cannot discover. Sir Robert Sibbald, indeed, places the falco gentilis, $\dagger$ or tercel gentle, in these isles; but all my search for this bird has as yet been in vain. Indeed, the falcons are a genus of birds whereof specimens are generally difficult to procure, except the more ignoble, as the hen-harrier, \&c. which is often shot in the yards; however, if my want of information in this genus could stir up any to help me, 1 should think it a point gained, to render these I have observed completer, and acknowledge the favour.

In the bill for dissolving and disannexing the earldom of Orkney from the Crown, we find the find following particular: "That all hawks be reserved to his Majesty, with the "falconers salaries, according to ancient custom." 


\section{GENUS II.-THE OWL.}

Gen. Char.-Bill hooked; base covered with bristles; no cere; nostrils oblong; tongue cleft at the end; eyes very large and protuberant, surrounded by a circle of a feathers; head very large and round, full of feathers; ears large and open; outmost toe versatile, or capable of being turned back, so as to act with the back toe; claws hooked, and sharp.

\section{Species I.-The Eagle-Orol.}

Bubo Maximus, nigri et fusci coloris, Sib.Scot. 14. Great Horn or Eagle Owl, Wil. Orn.99. Raii Syn. Strix Bubo, Lin. Sys. 131. Brit. Zool. Illus. 10. tab. 16. Orc. Katogle. Stock Owl, Wal. Desc. of Ork.

This bird I have never seen, but am credibly informed is still to be found in the Orkneys, especially in the hilly parts, where it is often surprised sleeping. When the horns are erected, I am told it has very much the appearance of a cat, whence the Orkney appellation. Not having a specimen, I shall give the description of this bird from Mr Pennant's British Zoology, a book worthy to be read by every lover of natural history, and ought to excite every one to give him what assistance is in his power, to the perfecting of a plan which is not in the power of any one man, though, like Mr Pennant, indefatigable, to accomplish.

"In size it is almost equal to the eagle; the irides bright. " yellow; the head and whole body finely varied with lines, " spots, and specks of black, brown, ash-colour, and ferrugi- 
" nous; the wings long; the tail short, marked with dusky " bars; the legs thick, covered to the end of the toes with a " close and full down, of a pale yellowish brown; the claws "great, much hooked, and dusky."

\section{Species 2.-The Short-Eared Orel.}

Brit. Zool. 156.

THIs bird I shot in the hills of Hoy, where it is very frequent, and builds its nest among the heath. It is impudent in breeding-time, sometimes catching up chickens from the doors. I have likewise seen it in chase of pigeons in daylight, which is not ordinary with the owl kind. In a nest I found in Hoy were the remains of a moorfowl, two plovers, besides the feet of several others, and the birds, two in number, ready to fly; the nest was in a large heath-bush, made without any art ; intolerably fetid, by reason of the heat of the weather, which had putrified some part of the provisions ; and which was still increased by the dung, \&c. of the birds, which the parents did not seem so attentive to remove as I have observed the smaller birds upon such occasions. The descripof this bird is as follows:

The length of this bird was thirteen inches, the breadth three feet; the weight ten ounces and a half; the bill strong, and much hooked, of a blackish horn-colour, almost buried amongst a set of white bristly feathers; the eyes large and full ; the irides 
a most beautiful colour, commonly yellow; the pupil large, with a nictitating membrane; the eyelids covered with black bristles, round them a circle of white, mixed with tawny; the crown of the head brown, variegated with lighter colours. Above each eye stood a single feather, taller than the rest, the half of which (or one web) was black and the other white. While the bird lived, and was suddenly startled, it would erect these like small horns, and fall a hissing like a cat; but the horns were scarce discernible when it died, unless to a nice inspection, in which it would be seen that they covered more of their neighbours than they ought. The ears were surprisingly large, opening from the neck to the throat, surrounded with a set of small parti-coloured feathers. The back of the head was covered with brownish feathers, edged with grayish yellow; the back and coverts are brownish, edged with a dull yellow. The legs, to the nails, are covered with whitish yellow feathers; the quills are dusky, barred with red, the second feather serrated ; the tail brown and spotted ; the breast and belly a dirty yellow. 
Of Owls with smooth heads.

\section{Species 3.-The White Owol.}

Common Barn, White, or Church-Owl, Howlet, Madge-Howlet, Gillihowter, Wil. Orn. 104. Raii Syn. 25. Strix Flammea, Lin. Syst. 133. Brit. zool. $15 \%$.

The Hulote, as it is here called, is found in the more retired places of Hoy in summer, where it builds; at other times is more domestic, and ventures into out-houses, ruins, churches, \&c. where it continues all day, if not disturbed, asleep ; in the night looks out for prey, which is mice, small birds, and other creatures it can master.

\section{Species 4.-The Brown Owl."}

The Gray Owl, Wil. Orn. Raii Syn. Av. 26. Strix Ulula, Lin. Syst. 133. Brit.Zool. 159.

THrs species is found in the more billy parts in summer, but $I$ never saw nor heard of it in winter, so I suspect it a migratory bird, though of this I am not certain; and, indeed, this species is much shyer than the rest, and worse to come at, keeping much more in its retreats than them, and not so impudent as the short-eared species before described; as for the 
magde-howlet, it may be considered every where as nne of these creatures that nature has, in some measure, tamed, and given to man to be domesticated, for its retreats are so near him that a little familiarity, I imagine, would render this creature, who in a manner offers its services to mankind, almost as useful as its kindred cat, and not a bit more mischievous than the greater part of these but half-tamed and ever suspicious domestics. There are none of the butcher kind in Orkney that ever I could find

\section{ORDER II.-PIES.}

\section{GENUS III.-CROWS.}

Gen. Char.-Bill strong; upper mandible a little convex; edges cultrated; nostrils covered with bristles reflected over them; tongue divided at the end; toes three forward, one backward; the middle joined to the outmost as far as the first joint.

\section{Species 1.-The Raven.}

Will. Orn. 121. Raii Syn. Av. 39. Corvus Corax, Lin. Sys. 155. Brit.Zool. 166. Corvus, the Raven: Nostralibus, the Corbie, Sib. Scot. 15. Orc. Corby.

Is the winter and spring vast flocks of corbies are seen here, but are very wild ; when breeding-time draws near they grow 
much thinner, many of them, I suppose, going off to other countries to breed. However, many continue here the whole year, as the country people, who live in the more hilly parts, daily experience to their loss ; for in the time of hatching, and when the young flight are out, the parents become very impudent and voracious; then lambs, pigs, and chickens are destroyed in numbers; and though the corby has not strength to carry away a lamb or pig, yet it tears out their eyes, entrails, and what it can manage.

The bill and claws of this bird are very strong, the latter much hooked. The colour is black, with a fine gloss; the legs black, as are all the larger feathers; the belly dusky.

The quill-feathers make excellent writing-pens, are very strong and elastic, and last long.

In hard winters the raven comes nearer the towns than usual for such a shy bird; then he is frequently seen by the shores, and even within a stone's-throw of the houses of Stromness, picking up what garbage, \&c. he can find, but retires from us at the return of spring, and betakes himself to the precipices of the hills and rocks, and sometimes to the steeples of the churches, or any ruined building, and there he makes his summer's retreat, levying contributions on all around; far from so generous in this respect as our country-folks say of the eagle, who (they tell us) takes but a hen from every house of the parish, and none* from those in the neighbourhood of his royal nest.

* Vide tit. Erne; the note and quotation from Thomson. 
Ravens have been sometimes seen white, and though this is but seldom the case, I have heard of two or three examples, both in these and rooks, though not all in Orkney: of the latter it was impossible, as they are seldom, if ever, seen here.

\section{Species 2.-The Royston Crow.}

Will. Orn. 124. Raii Syn. Av. 36. Mart. Disc. West. Isles, 376. HoodedCrow, Sib. Scot. 15. Corvus Cornix, Lin. Sys. 156. Brit.Zool.169. Orc. Crow.

VERY numerous here through the whole year; like the other builds in the rocks, and in breeding-time is destructive to chickens ; at other times is not so bold, but contents itself with any garbage, or the insects that breed in dung, \&c.

It is more familiar than the corby, and continues the whole winter about the houses, till the calls of love draw it out with the rest of the feathered tribe to their summer retreats.

Its nest is composed of a great quantity of sticks, placed in the hollow of a rock (trees we have none fit), and lined with softer materials, such as wool, pieces of rloth, and, in a word, . every thing it can pick up. It lays from four to six eggs, which are green, spotted with black, as those of the other species of the crow kind mostly are.

These meet in the spring in vast flocks, as if to consult the important affairs of summer, and, after flying about in this 
[Birds.

manner for eight days or so, separate into pairs, and betake themselves to the mountains.

Species 3.-The Jack-Daw.

Wil.Orn. 125. Raii Syn. Av. 40. Corvus Monedula, Lin. Sys. 156. Brit. Zool. 175. Scotis et Orc. Kae. Brit. Zool. Illus. 52. tab. 54.

Turs bird, I am informed, is to be found in the breedingtime in the rocks of South Ronaldsha, Walls, \&c. where they make their nests, with the rock-pigeons and stares, in the holes of the rocks.

"It is," says Mr Pennant, " a docile, loquacious bird, to " which we may add, impertinently curious, thievish, fond of " every thing glittering, which, if it can snatch, it carries to " its retreats out of reach; where in a tame state, I have seen " it lay up a quantity of stuff it could make no use of,--a pro" per representative of a miser, who thinks himself happy to " add another glittering piece to the hoard, even though he " perhaps dares make no more use of them, than the daw " can of his magazine of rags, childrens' jewels, bits of glass, " and halfpence."

These are what of the crow kind I have observed, or have been informed of, in the Orkney Islands. Our want of woods hinders most of the pies, or pie kind, from settling here, even though there is perhaps no other reason to be given for our want of them. 'The magpie is never seen here, though so 
frequent in Scotland that few farm-yards that have trees in them, but they are the tenants of. Rooks are reckoned ominous, if ever they appear here*; and for the woodpeckers ${ }^{*}$, I do not think we have one of the genus.

\section{GENUS IV.-THE CUCKOO.}

Gen.Char.-Bill weak, a little bending; nostrils bounded by a small rim; tongue short, pointed; toes two forward, two backward; tail cuneated, it consists of ten soft feathers.

\section{Species 1.-The Cuckoo.}

Wil. Orn. 97. Raii Syn. Av. 23. Cuculus Canorus, Lin. Sys. 168. Brit. zool. 182. Brit. Zool. Illus. 53. tab. 55. Female. Sib. Scot. 15. Orc. Gouk.

Thovgr rarely, the Cuckoo is found in the retired and wild hills of Hoy and Walls, where it finds a nurse for its offspring, which it seems either unwilling or incapable to care for. The titlark, or other small bird, hatches for this species, and we very seldom see a cuckoo on the wing in the breeding-

* When a rook is seen, people expect a famine to follow soon after.

† I shot in a garden in Stromness last year (winter, 1774), a lesser spotted woodpecker; but this was only a strayed bird, none of the kind ever having been seen here before. 
season without one of these attending it, insomuch, that in Scotland it has become proverbial of an officious attendant.

The kingsfisher should come in here, according to its order in ornithology, but, though I once saw a specimen which had been drove here, I suppose, by a storm, I not think it is an Orkney bird, or makes us so regular visits as to deserve a place here ; indeed, were it true that Ovid says, of her having seven calm days in the depth of winter for hatching, she could have no such conveniency in these, far from Halcyon climates.

In the same class we may place the Hoopoe*, which Sir Robert Sibbald + has placed here. Mr Wallace, from whom I suppose Sir Robert had the account, says, "He saw one " that had a long beak, a large tuft on the head, in the fa" shion of a crown, with speckled feathers, pleasant to be" hold, which he believed to be the Upupa ;" but he places it amongst the " exotic fowls, driven in by the wind in time " of a storm."

Mr Pennant has given this bird a place in his excellent British Zoology, but tells usit visits Britain frequently, though not at stated seasons ; but for being once in Orkney cannot be said to be so naturalised, as to merit a place in an Orkney Fauna.

Storms, indeed, frequently compel many of the migratory birds to take these islands in their route, but they are almost always half-dead ere they come, or, if in spirits, soon go off again.

* Vide Pen. Brit. Zoul. 195. + Vide Sib. Prod. Nat. Hist. Scot. III. p. 16. 


\section{ORDER III.-GALLINACEOUS.}

\section{GENUS V.-THE GROUSE.}

Gen. Char.-Bill convex, strong, and short; a naked scarlet skin above each eye; nostrils small, and hid in the feathers; tongue pointed at the end; legs strong, feathered to the toes, and sometimes to the nails; the toes of those with naked feet pectinated on each side.

\section{Species 1.-The Grouse.}

Red-game, Gorcock, or Moorcock, Wil. Orn. 177. Lagopus Altera, Plinii. Raii Syn. Av. 54. Moorcock, or Moorfowl, Sib. Scot. 16. Brit. Zool. 204. Brit.Zool. Illus. tab. 13. fem.

Found in the hills of Hoy, Walls, Rousa, the hills called the Hills of Ireland, Evee, Rendal, Holm, and in several other moors through these islands; pretty numerous in some places, though not so much so as in the hills I have been acquainted with in Scotland.

Partridges were transported into this country some years ago, and placed in Walls by the then proprietor, but I scarce think they have come to any thing. I once saw one of them which was shot (by mistake) in Hoy, which is about twelve miles from the place where they were first placed, but never heard of any other of the original colony, though it consisted of several pairs, or of their offspring; I suppose they had been all destroyed by the ravenous birds, or wanted shelter to breed in, as the nature of that bird is to hide amongst corn, 
broom, whins, \&c. none of the two last of which it could have here.

\section{ORDER IV.-COLUMBINE*.}

\section{GENUS VI.-THE PIGEON.}

Gen. Char.-Bill weak, slender, strait at the base, with a soft protuberant substance, in which the nostrils are lodged; tongue entire; legs short, and are likewise red; toes divided to the origin; swift and distant flight; walking pace, \&c.

\section{Species 1.-The Common Pigeon.}

Common Wild-Dove, or Pigeon, Wil. Orn. 180. Columba Rupicola, Sib. Scot. 17. Columba Oenas, Lin. Sys. 279. Brit. Zool. 216. Brit. Zool. Illus. tab. 8. fig. 2.

Found in its wild state round all the rocks of the mainland and isles, where they build in the caves, but retire farther in than the auks, gulls, or most other sea-fowls, except some of the petrells, \&c. which build in holes of the earth, as will be seen in order.

Pigeons fly in vast flocks, and do no small damage amongst the corn, but especially among peas and other legumes. In winter they are forced into the farmers' yards, where great

* For the reason of this order, vide Pen. Gen. of Birds, p. 28. 
numbers are killed, but they very soon recruit again, owing to their being numerous breeders. A description of the rockpigeon is as follows :-

The wild pigeon from the rock weighs thirteen ounces and a-half, the length thirteen inches, breadth twenty-five inches. The colour of the head a fine blue; the bill slender, hard at the point ; the root of the upper mandible soft, and, as it were, covered with meal. The breast a fine changeable green and purple; the neck a shining copper-colour. The shoulders, and lesser coverts, a light ash-colour; the lower part of the back, and under the wings, a fine white. The rump and tailfeathers blue, with a cast of ash-colour, the latter barred at the points with black. In some individuals the two outermost feathers of the tail have the external webs white. The wings are crossed with two black bars : The legs short; these and the feet red, bare of feathers ; the toes divided to their origin, with black claws*.

A few white pigeons may be seen in the flocks from the headlands and rocks, but these are infrequent, and probably strayed birds from the pigeon-houses, which sometimes happens, where they intermix with the tame ones in their flight for plunder.

I have observed another species of pigeon in Orkney, in a domestic state, but where they were brought from I am igno-

* Among a great number I shot this winter (1775-6), found several varieties of colour. One with the back and coverts curiously mottled with black feathers; another had the ash-coloured feathers of its back tipt with gray, which produced a curious waving, \&c. 
rant. This species has the general appearance of the rockpigeon, only the size is less, the bill shorter, and the feathers on the back of the head are turned up towards the head. It is the jacobine pigeon of authors, and the Columba cucullata* of Linnæus ; but neither does he tell us its place of residence. Gesner + calls it the Columba Anglica, s. rupica; and $\mathrm{Mr}$ Pennant + gives it as a variety produced from the domestic pigeon, the general likeness of which it surely has, especially the nearer the latter comes to its original state.

\section{ORDER V. PASSERINE.}

\section{GENUS VII.-THE STARE.}

Gen. Char.-Bill short, depressed; nostrils guarded above by a prominent rim; tongue hard and cloven ; toes, the middle joined to the outmost as far as the first joint.

\section{Species 1.-The Stare.}

Stare, or Stareling, Wil. Orn. 196. Raii Syn. Av.6\%. Sturnus Vulgaris, Lin. Sys. 290. Brit. Zool. 231. Brit. Zool. Illus. 57. tab.61. fig. 2.

THIs is a harmless, prattling, mimic bird, found in thousands in the Orkneys; breeds in old houses, churches, the

* Lin. Sys. 280. † Gesner, (as quoted by Lin.)Av.279。 $¥ B$ Brit.Zool. I. 218. 
sea-rocks, \&c.; seems to bea favourite in Orkney, as few houses are built but they leave several holes in the wall for its convenience, of which it always, as if sensible of the favour, avails itself, and repays it with a song, and a deal of its antic mimicry.

I have often been much diverted to hear a couple of cock stares, perched upon two opposite chimneys, trying to excel one another in imitating all the noises below, the crowing of cocks, cackle of hens, barking of dogs, mewing of cats, particular notes of different wild birds; all this intermixed with its own natural harsh discordant squeak; insomuch, that a macaroni from every nation in Europe, placed together to dispute concerning some important alteration to be made on a button-hole, or the best method of scenting a bouquet, could not make a more dissonant jangle than these birds, when in the humour of mimicry.

The stare feeds on worms and insects, and in winter when the earth is locked up with frost, comes down to the sea side, where it lives on the * sea-louse (as it is here called), insinuating the point of its bill under the stones, and hastily opening it, jerks the stone over, immediately seizing what may be underneath.

The flesh of the stare is very bitter, but this may in some measure be remedied, by wringing off the head of the bird immediately as caught, that the blood, in which the bad taste is, may run from it. Young stares are tolerable eating.

* Cancer Locusta, Lin. Syst. Nat. 1055. 
This bird is well known, and as well described in Mr Pennant's British Zoology, a book in so many hands, as to render a particular description here unnecessary, only I shall observe, that the young birds do not acquire their perfect colours for the first year, but are of an uniform dusky brown, with a yellowish stripe running from the lower jaw down to the breast ; and, besides, may be known by their particular note. I have heard of one example of a stare, in the nest of which there was four young, two of which were black, the others gray, and grew whiter as they grew older.

I imagine stares breed twice a-year, as the first brood has left the nest now in June, and I have observed them very busy in repairing their nests, and rearing another in August.

\section{GENUS VIII.-THE THRUSH KIND.}

Gen. Char.-Bill strait, obtusely carinated at the top, bending a little at the point, and slightly notched near the end of the upper mandible; nostrils open and naked.; tongue slightly jagged at the end; toes, the middle joined to the outmost as far as the first joint; the back toe very large.

\section{Species 1.-The Fieldfare.}

Will. Orn. 18s. Raii Syn. Av. 64. Turdus Pilaris, Lin. Sys. 291. Brit. Zool.225. Sib. Scot. 17.

Tне Fieldfare, I have been informed, makes us pretty regu- 
lar visits in the fall of the year, but neither builds nor continues the winter with us. I suppose it comes from the northern climates, upon the setting in of their severe winters, and touching here in its passage, finds no such store of berries, its food, as to induce it to stay with us, so that it is forced for want to shift its quarters.

Species 2.-The Song-Thrush, or Throstle.

Mavis, Throstle, or Song-Thrush, Wil. Orn. 188. Raii Syn. Av. 64. Turdus Musicus, Lin. Sys. 292. Brit. Zool.226. Orc. Mavis.

The Mavis is found among the bushes in the glens of Hoy; it also frequents the gardens of Kirkwall, making its finelyplastered nest among the shrubs and fruit-trees.

Sings most beautifully in the spring while breeding-time continues, but here seldom heard at any other time; continues with us through the whole year.

\section{Species 3.-The Redwing.}

Redwing, Swinepipe, or Wind-Thrush, Wil. Orn. 189. Raï Syn.Av. 54. Turdus Iliacus, Lin. Sys. 292. Brit. Zool. 227. Turdus Iliacus, sive Illas, aut Tylas; the Redwing, or Wind-Thrush, Sib. Scot. 17.

ONE of our autumnal visitors; seems in some places to stay 
[Birds.

better than the former. I observed a pair of these in Hoy thiough the greatest part of the summer, and imagine they build among the bushes there, though with the striclest search I could not discover the nest.

\section{Species 4.-The Blackbird.}

Wil. Orn. 190. Raii Syn. Av. 65. Turdus Merula, Lin. Sys. 295. Brit. zool.228. Brit. Zool. Illust. tab.60. Sib. Scot. 17. Orc. Blackbird, Hoy, Chucket.

THE Blackbird is found in pairs in summer in Hoy, and in winter in single birds; comes sometimes to the gardens ; a very shy and retired bird, seldom seen, keeps low in the bushes, and if surprised does not fly straight forward, but escapes among the roots of the trees or brushwood.

The blackbird has, in breeding-time, a fine strong note, which makes all the hills re-echo; but in winter loses this, and instead of it has only a squeaking note, like the word chuck, chuck, several times repeated, whence the Hoy name.

I have seen them elsewhere bred in a cage, and make excellent song-birds, if at a distance, but their pipe is so strong that it is sufficient to deafen one, when placed too near.

The colour of the blackbird is the occasion of its name in English ; and in old birds a fine black, the bill yellow, as are the edges of the eyelids. In young birds of any kind the colours are not so clear as afterwards; in this species they are a rusty black, so as not to be distinguished from the females ; 
but, like most of the smaller birds, they attain their true colours at about a year old.

\section{GENUS IX.-THE GROSBEAK.}

Gen. Char.-Bill strong, convex above and below, very thick at the base; nostrils small and round; tongue, as if cut off at the end.

\section{Species 1.-The Sparrow.}

The House-Sparrow, Wil. Orn. 249. Raii Syn. Av. 86. Fringilla Domestica, Lin. Sys. 323. Brit. Zool. 300. Brit. Zool. Illus. tab.65. fig. 1,2.

Mr Pennant, in the British Zoology, has placed the sparrow among the Grosbeaks, and made it and the greenfinch connect these with the finches; and, indeed, the strength and largeness of the bill seems to favour the placing it there, though Linnæus has ranked it with the finch tribe.

Sparrows are here in myriads; make a vast destruction amongst early corns : I have seen a small field of early barley almost all picked by these little voracious wanderers.

Build everywhere, in holes of walls, and wherever they can get the least shelter; often beat the stares from the holes left in the walls for them, by our good-natured Stromnesians, and possess them in spite of the tenant, and to the grief of the owners, who are fond of the mimic-songster stareling, but 
[Birds.

hate the pert, mischievous sparrow; however, if it is in a place where the people are not fond to go to, the latter always makes good his possession.

\section{GENUS X.-THE BUNTING.}

Gen. Char. - Bill strong and conic, the sides of each mandible bending inwards; in the roof of the upper mandible a hard knob, of use to comminute or break hard seeds,

\section{Species 1.-The Bunting.}

Wil. Orn. 267. Raï Syn. Av. 93. Emberiza Miliaria, Lin. Sys. 308. Brit. zool.318. Sib.Scot. 18.

The Bunting continues with us the whole year, builds in the fields of corn, often in a tuft; shot in the farm-yards in winter in great numbers ; is good eating, being full and fat.

The bill is strong, and furnished with a knob in the roof of the upper mandible, excellently fitted to break and bruise the hardest seeds; a wise contrivance of Providence, which adapts every organ in different creatures to their different ways of life. The whole upper part of the body is yellowish brown, mixed with black strokes; the belly much lighter, and in many the breast is black, or spotted pretty thick with this colour; but this perhaps is in young birds. The quill-feathers 
are dusky, with the outer webs yellow; the tail forked, the edges white; the legs yellowish.

The bunting, like others of the genus, pleases our palate more than our ear ; it is no song-bird; the note consists in a lengthened skirle (Scotis), which it repeats every now and then, sitting on a bush or stalk of mugwort in the fields.

\section{Species 2.-The Greater Brambling.}

Great Pied Mountain Finch, or Brambling, Wil. Orn: 255. Raii Syn. Av. 88. Emberiza Nivalis, Lin. Syst. 308. Brit. Zool. 321. Brit. Zool. 1llus. 17. tab. 11. fig. 2. Snowflake, Snowfleck, Scotis et Orc.

THe Snowfleck, or snowflake, is a migratory bird with us, and in some years appears in vast flocks from the northward, continuing with us most part of the winter, but as soon.as spring appears goes off, and we see no more of them till the hard weather sends them again to us.

The weights of three I killed in Orkney (February 3.), were a little different, one of them a few grains heavier than the other ; this last was one ounce, two grains and a-half. The rest of their description exactly corresponded with that given us by Mr Pennant in the British Zoology, Vol. II. 321.

I have only to add, that I have often seen some of these birds lighter-coloured than others, that is to say, the tawny of the head very pale, the back dusky, and very much of the wings white. 
The hind-claw of these was much longer than in Mr Pennant's figure, but whether specifically different I am uncertain.

The above author tells us, a few of them build on the summits of the highest mountains, with the ptarmigans, but from what I can be informed, none of them remain with us. Of the ptarmigans we have none, I suppose for want of proper food.

\section{GENUS XI.-FINCHES.}

Gen. Char.-Bill perfectly conic, sharp towards the end, and very sharp pointed.

\section{Species 1,-The Chaffinch.}

Wil. Orn. 253. Raii Syn. Av. 88. Fringilla Coelebs, Lin Sys. 818. Brit. Zool. 307. Orc, (often mistakenly), Snowfleck.

Chaffinches are seen with us in spring, but whether they continue I am uncertain; perhaps a few may build in Hoy among the shrubs and in the gardens, but this species is unfrequent in summer. 


\section{Species 2.-The Linnet.}

Wil. Orn. 258. Raii Syn.Av. 90. Brit. Zool.311. Orc. Linnet, or Lint-twite.

This little songster is very common through these islands. It builds anong the shrubs on the burn sides, and even among the heather. The nest is constructed of small straws, bent, hair, and wool, for the inside ; lays from four to six whitishspotted eggs.

The linnet is much sought after as a song-bird, and confined in cages almost in every house ; some particular birds of them will sing almost the whole year, more or less, whilst others only in the spring; in general, I suppose, this depends on the sex of the bird, and its management.

This species never migrates ; may be caught in great numbers in the snows of winter, by throwing down a parcel of chaff; seeds, \&c. and placing a clap-net, or, for want of that, a riddle for winnowing corn, with a contrivance to make it fall down on the birds. The linnet is easily tamed, and even when caught old soon goes to its meat, and is familiarized to its condition. 


\section{Species 3.-The Lesser Red-headed Linnet.}

Wit. Orn. 260. Raii Syn. Av. 91. Fringilla Linaria, Lin. Syst. 322. Brit. Zool. 313.

I HAVE killed a few of these among other small birds of this genus; especially they are to be seen about the farmers' yards in winter; a very small bird; the forehead purple; in the male the breast the same; by this mark it may be known from the other linnets.

Builds in Hoy, among the small shrubs, heath, \&rc.

Species 4.-The Mountain-Linnet, or Twite.

Wil. Orn. 261. Raii Syn. Av.91. Brit.Zool. 315. Brit.Zool. Illus.tab.66.

The Twite is easily distinguished from the other linnets by the beautiful purple spot on its rump. It is smaller and longer-bodied than the common linnet; the tail is longer in proportion; in other respects it is not very easily distinguished from it.

The twite continues with us the whole year; builds in the heath, seldom, if ever, in bushes; is common among the flocks of common linnets in winter. 


\section{GENUS XII.-THE LARK.}

Gen. Char.-Bill strait, slender, bending a little towards the end,'sharp pointed; nostrils covered with feathers and bristles; tongue cloven at the end : toes divided to the origin; claw of the back-toe very long, and either straight, or very little bent.

\section{Species 1.-The Sky-Lark.}

Wil. Orn. 203. Raii Syn. Av.69. Lin.Sys. 287. Brit. Zool. 233. Brit. zool, Illus. tab. 62 .

Thovgr we cannot boast with more fortunate climates of the music of the nightingale, or the beauty of other's of the feathered race, we are in great measure kept in countenance by the very early carols of this rural songster.

The lark begins to sing with us on the first days of February, and continues most part of the summer, soaring very high, generally near its mate, whose toil of brooding is thus alleviated, and her spirits cheered with the voice of love.

To rise with the lark is a proverbial expression, as old as Solomon*; and, indeed, one must be an early riser who

* Vide Ec. chap. xii. v. 4. 
Hears the lark begin his flight, And singing startle the dull night, From his watch-tower in the skies, Till the dappled morn doth rise.

Nothing, however, is more cheerful than a spring-morning scene, though too seldom enjoyed by the politer part of the world, who for the most part lose the morning, the most valuable part of their time, and are obliged to eke it out with nightly dissipation. Nothing can be more conducive to the health, both of body and mind, than to start with the earliest dawn,- to hear the enlivening music of the groves, mixed with the contented voice of labour, the whistle of the ploughman, and the lowing of the herds, - to see the rising of the sun, and the smoking glebe.

The lark loses his voice when the season of love is over, as do most of the wild birds, this being only indulged at that time to recommend themselves to their mistresses, and soften the fatigue of providing for their families.

'Tis love creates their melody, and all

This waste of music is the voice of love;

That even to birds, and beasts, the tender arts

Of pleasing teaches.

Connubial leagues agreed, to the deep woods

They haste away, all as their fancy leads,

Pleasure, or food, or secret safety prompts;

That nature's great command may be obey'd. 
The patient dam assiduous sits,

Not to be tempted from her tender task,

Or by sharp hunger, or by smooth delight,

Tho' the whole loosen'd spring round her blows.

Her sympathizing lover takes his stand

High on the opponent bank, and ceaseless sings

The tedious time away; or else supplies

Her place a moment, while she sudden flits

To pick the scanty meal.

Species 2.-The Tit-Lark.

Wil. Orn. 206. Raii Syn. Av. 69. Alauda Pratensis, Lin. Sys. 287. Brit. Zool. 237. Sib. Scot. 17. Orc. Titing.

The Tit-Lark is common; in summer withdraws to build in the hills and fields, but in winter comes down to the seaside, where it feeds on insects, such as sea-lice, \&c. ; sometimes approaches the very doors, as if to demand help from man, the engrosser of every thing, in that rigorous season.

In spring it has a fine but uniform note, at least not near so much variety as in that of the other larks. Then it retires from the sea, and may be seen very common in the valleys of the hills of Hoy, \&c. where it builds a nest in the burn banks, among the grass, of the same materials as others of the genus.

This species is much less, and more slender than the common lark; the bill smaller and longer in proportion; the whole upper side is of a dusky-green, in some birds blacker than 
others; the throat white; the breast spotted, on a yellowish ground; the legs very slender, the claw on the hind toe, as in the others, long; the tail dusky, edged with white.

\section{GENUS XIII.-WAGTAILS.}

Gen. Char.-Bill weak and slender; tongue lacerated at the end; legs slender.

\section{Species.-The White Wagtail.}

Wil. Orn. 237. Raii Syn. Av. 75. Motacilla Alba, Lin. Sys. 331. Brit. Zool.275. Brit. Zool Illus. tab. 62.

TH Is is one of the (with us) migratory small birds ; it comes early in the spring, builds in holes of walls, and when this is over immediately retires. Its constant haunts are near watery. places, where it feeds on flies and other insects, and constantly attends the plough to pick up small worms.

The white water-wagtail continues the shortest time with us of any of the migratory birds which build here; I cannot condescend on the exact time of their departure, but have never seen one after May.

It is a very beautiful bird ; the colours, though not many, are bright; the face and sides of the head are white; the back of the head, back; and throat, to the breast, are black; breast (in some) and belly white; the wings are striped with white, 
the quill-feathers dusky; the tail, which is almost always moving, is long, the colour is black, except the outermost feather on each side, which is almost all white; the legs are black, slender, the hind-claw long, as in the lark kind.

\section{GENUS XIV.-WARBLERS.}

Gen.Char.-Bill slender and weak; nostrils small, sunk; tongue cloven ; feet, the exterior toe joined at the under part of the last joint to the middle toe.

\section{Species 1.-The Redbreast.}

Robin Redbreast, or Rudock, Wil. Orn. 219. Raii Syn. Av. 78. Motacilla Rubecula, Lin. Sys. 337. Robin, Orc. Brit. Zool. 260.

THE attachment of this little harmless stranger to mankind, and its strength of mind, (shall I say), in flying from the rigours of winter to his habitations, often from a less to a greater danger, is so prettily described by Thomson in his Winter, that I hope I shall be forgiven in transcribing the passage.

\section{One alone,}

The redbreast, sacred to the household gods,

Wisely regardful of th' embroiling sky,

In joyless fields, and thorny thickets, leaves

His shivering mates, and pays to trusted man 
His annual visit. Half afraid, he first

Against the window beats; then, brisk, alights

On the warm hearth; then hopping o'er the floor,

Eyes all the smiling family askance,

And pecks, and starts, and wonders where he is :

Till more familiar grown, the table crumbs

Attract his slender feet.

'The robin never migrates from these isles; is seen through the whole winter about the houses or barns ; builds in the holes of walls or rocks, or sometimes in the warped roots of trees, or such like places, but always very retired.

It is easily known by its breast, but more to the country people by its constant visits.

Said to be much addicted to fighting, especially with its own kind, insomuch, that one tree will not bear at one time two redbreasts.

\section{Species 2.-The Wren.}

Will. Orn. 229. Raii Syn. Av. 80. Motacilla Troglodytes, Lin. Sys. $33 \%$. Brit. Zool. 268.

The least of our birds; does not migrate; like the last species comes near the habitations of men in the winter season; breeds in the holes of walls, making a very large nest of moss, lined with softer materials, with a door for entrance; lays a great number of eggs; I have counted sixteen in one nest, 
which well may be called a miracle, how it can rear such a number of young without missing one; but this is done by the power and providence of that Being, who implanted the first seeds of knowledge into the minds of all animals, and who takes care not only of the greatest, but of the most minute parts of the creation.

The wren is a little neat bird, carries its tail almost erect, seems not to be able for long flights, as I have heard of them run down and caught. The whole upper part of the body is a dark-brown, the wings and tail neatly barred with darker colours.

\section{Species 3.-The Golden-Crested Wren.}

Will. Orn. 227. Raii Syn. A0. 79. Motacilla Regulus, Lin Sys, 338. Brit. zool. 267.

THIs most beautiful species is pretty frequent with us ; continues all the year round. I saw one of them run down in winter. It appears not to have a strong wing; takes but small flights. In very hard winters it creeps into holes of houses and quarries, where I have found them ; particularly in breaking up several layers of a fine figured slate-quarry in Corn-holm of Copinsha, I found a golden-crested wren at the farthest end of a chink, and where it was confined by the falling in of the rubbish.

Its fine crest distinguishes it from all others of our small birds, as well as. its bulk, which scarcely equals the wren; 
besides its make is more slender and longer than the other.

\section{Species 4,-The Wheat-Ear.}

Wheat-Ear, Fallow-Smitch, White-Tail, Wil. Orn. 233. Raii Syn. Av. 75. Motacilla Oenanthe, Lin. Sys. 332. Brit.Zool. 269. Orc. Chack.

Trirs is a migratory bird, but stays with us till the end of harvest; goes off in winter, but to what place I am unacquainted. The country people tell us they are sleepers, and have been found in a torpid state in the winter season in old walls, under great stones, \&c.; however this is, they entirely disappear, and revisit us in April. They build in old walls, either stone or earth, under stones, and such like places; make a large nest of straws, grass, and line it with horse-hair ; lay a number of eggs, (generally six), of a bluish-green colour, large for the size of the bird. They are very solicitous for their young; make a great deal of chattering when one is near the nest; live on insects, which they are very nimble in catching, worms of all kinds, but no grain, as far as I have observed.

whe young follow their parents while they are here ; do not acquire their true colours for the first year; are much spotted about the head and breast; the black stroke on the eye does not appear as in old birds; and they have a general gray appearance, except the tail, which is black, and the rump white, by which they may easily be known. 
This bird, for what reason I cannot say, seems to be proscribed in Orkney. Young and old destroy both eggs and birds of it, and this not for any other end but the seeming effects of wanton cruelty, as it seems a quite harmless creature. We may attribute this to that unaccountable prejudice, which sometimes gets into the human heart, against particular places and things, and which is carefully propagated to us by our nurses.

\section{GENUS XV.-THE SWALLOW.}

Gen. Char.-Bill short, broad at the base, small at the point, and a little bending; nostrils open; tongue short, broad, and cloven; legs short; tail forked; wings long.

\section{Species 1.-The House-Swallow.}

House, or Chimney-Swallow, Wil. Orn. 212. Raii Syn. Ao. 71. Hirundo Rustica, Lin.Sys.343. Brit.Zool. 242. Brit.ZZool. Illus. 12.tab.9. fig.1.

TH Is bird is found, though not in great numbers, in Kirkwall, where it builds its nest in the house chimneys. As elsewhere, it migrates from us in winter, as our country cannot at that rigorous season afford it insect-food, its sustenance. 


\section{Species 2.-The Martin.*}

Martin, Martlet, or Martinet, Wil. Orn. 213. Raii Syn. Av. 71. Hirundo Urbica, Lin.Sys. 344. Brit.Zool. 243.

The only place I have observed this species in Orkney is the great church of Kirkwall, where they make their clay nests in the corners of the windows. In Scotland 1 remember to have seen them build in rocks, and in the arches of bridges, particularly in one called the Gannachie-Bridge, in the shire of Angus, where they build in hundreds. Here they are less frequent; like the last they go off in winter.

\section{Species 3.-The Sand-Martm.}

Sand-Martin, or Shore-Bird, Wil. Orn.213. Raii Syn Av. 71. Hirundo Riparia, Lin. Sys. 344. Brit.Zool. 244. Orc. Witchuck.

Tris is the most common bird of the swallow-tribe in the Orkney Isles; builds very frequently in the banks of the loch of Stennes, and that of Skeal, in the sand. The nest is placed a good way under ground, and composed of all the soft materials it can pick together, such as hay, straw, feathers, \&c.

* I have observed the Black-Martin (Hirundo apus, Lin.) once or twice, but seemingly strayed birds. 
Mr'Thomson has most beautifully described this particular of the small birds' yearly task in his Spring, which, with a quotation or two from another author on the same subject, shall conclude this account of the land-birds in Orkney.

\footnotetext{
Some to the holly-hedge

Nestling repair, and to the thicket some;

Some to the rude protection of the thorn

Commit their feeble offspring : the cleft tree

Offers its kind concealment to a few,

Their food its insects, and its moss their nests.

Others apart, far in the grassy dale,

Or roughening waste, their humble texture weave.

But most in woodland solitudes delight,

In unfrequented glooms, or shaggy banks,

Steep and divided by a babbling brook,

Whose murmurs soothe them all the live-long day,

When by kind duty fix'd. Among the roots

Of hazel, pendant o'er the plaintive stream,

They frame the first foundation of their domes;

Dry sprigs of trees in artful fabric laid,

And bound with clay together. Now 'tis nought

But restless hurry through the busy air,

Beat by unnumber'd wings. The swallow sweeps

The slimy pool, to build his hanging house

Intent. And often, from the careless back

Of herds and flocks, a thousand tugging bills

Pluck hair and wool ; and oft when unobserv'd,

Steal from the barn a straw; till soft and warm,

Clean and complete, their habitation grows.
}

Spring, $l .633-657$. 
"Birds of the same kind make their nests of the same ma" terials," says an excellent author, "laid in the same order, " and exactly of the same figure; so that by the sight of the " nest one may certainly know to what bird it belongs; and " this they do though living in distant countries, and though " they never saw nor could see any nest made: that is, though " taken out of the nest and brought up by the hand; neither "were any of the same kind ever observed to make a differ" ent nest, either for matter or fashion*," \&c.

"I am never tired," says the author of the Spectacle de la Nature, "with observing the perfect similitude that appears " in all the nests of birds of the same species, - the difference " between that of one species, or of another, - and the indus" try, neatness, and precaution which reign through the " whole. You would smile to see the inhabitants come to " traffic at this fair : one wants a bit of moss ; another has " occasion for a feather; a third can't do without a straw; " you will see two outbidding one another for a lock of wool, " and this sometimes causes great quarrels ; however, the dif"ference is commonly adjusted, and each carries what she " can to her nest'."

It would be endless to point out all the beautiful observations that have been made on this sprightly part of the creation, and the reflections that may be drawn from these; every one's mind will suggest these to him, upon an attentive survey of this leaf of the book of nature.

* Ray's Wisdom of God in the Creation.

† Vide Spec. de la Nat. v. 1. Dial. 10, passim. 


\section{DIVISION II.-WATER-FOWL.}

ORDER VI.-CLOVEN-FOOTED, OR WADERS.

\section{GENUS XVI.-THE HERON.}

Gen. Char.-Bill long, strong, and sharp pointed ; nostrils linear; tongue pointed ; toes connected as far the first joint by a membrane; back toe large.

\section{Species 1.-The Crested-Heron.}

Common Heron, or Heronshaw, Wil. Orn. 277. Ardea Cinerea Major, seu Palla, Raii Syn. Av. 98. Ardea Major, Lin. Sys. 236. Brit. Zool. 339. Orc. Heron with a black top.

THIs bird is very frequent with us in winter; sometimes may be seen fifty in a flock, but then very shy: however, I have seen two or three shot in that season, which, though small in proportion to the length and breadth, were tolerable eating.

Whether this species continues with us or not, I am not positive, as I have never seen it in summer; rather think not, 
as those found here at that season are of the species next to be described.

The great characteristic difference of this from the following is the crest, which is long, and of a deep black in this, but grayish-dusky in the other; the head is white; the whole upper part of the body is ash-coloured; the lower part of the throat to the breast is a yellowish-white, most beautifully spotted with black, insomuch that at a distance it has the appearance of spotted ermine; the feathers are all long and loose; the belly white, with stripes of a very deep black; the legs a dirty green ; the toes long, and pretty strong.

Its long legs are thrown straight behind it in flying, as a counterpoise to its neck.

The places where they frequent most are all round the seashores of the different isles, the loch of Stenness, and in the night-time sit in flocks on the outer holm of Stromness, together with the next species, one always sitting higher than the rest, who no sooner sees any danger but he gives the alarm, and the whole flock betake themselves to flight.

\section{Species 2.-The Ash-coloured Heron.}

Aldrovandus, his third kind of Ash-coloured Heron, Wil. Orn. 279. Raii Syn. Av. 98. Ardea Cinerea, Lin. Sys. 236. Brit.Zool. 340. tal.6. Sib. Scot. 18.

Tue Heron, for such a small body, has a large flight, to 
enable it to go to very distant places in search of food ; long legs, for wading to a good depth in the water; and a long neck, and sharply-edged bill, to detain its prey when caught, and carry the most slippery fishes to a great distance, as it is often obliged to do with eels, \&c. \&c.

Sir Robert Sibbald places the crane in these isles ; but if this bird ever makes us visits, these must be very seldom and irregular.

Mr Wallace says the same of the bittern, "that it hath " been seen in this country;" but I believe we may easily say it is under the same class with the former, that of "irre" gular visitors," driven here, perhaps by a storm or other accident, once in a century. 


\section{GENUS XVII.-IHE CURLEW.}

Gen. Char.-Bill slender, long, incurvated : face covered with feathers; nostrils linear, longitudinal near the base ; tongue short, and sharp-pointed; toes connected, as far as the first joint, by a membrane.

\section{Species 1.-The Curlew.}

Wil. Orn. 294. Raii Syn. Av. 103. Scolopax Arquata, Lin, Sys. 242. Brit. Zool. 346.tab. 8. Numenius, sive Arquata, Sib. Scot. 18. tab. 12. fig. 1. Orc. Major, Stock-Whap; minor, Little-Whap.

The Curlew is one of the waders which is most frequent about these shores; found all round the country in flocks ; builds in all our most retired hills, such as Hoy, Walls, the hills of Harra, \&c. \&c.; lays very large eggs; an early breeder, like most of the waders, the brood on the wing in July.

The larger curlew, called here Stock-Whap, differs something in its colours from the lesser; the head and neck are much browner, whereas in the little one they are grayish and spotted ; the bill, feet, and in other respects they agree, except the size; but whether this is sufficient to constitute a specific difference I much doubt, though they are always distinguished by our rural" philosophers, - but they commonly examine by the bulk;

For what is worth in any thing,

But just as much as it can bring ! 
The curlew is here reckoned excellent eating, and much sought after; by some preferred to all other wild-fowl.

\section{GENUS XVIII.-WOODCOCKS, OR SNIPE-KIND.}

Gen. Char.-Bill two inches long and upwards; slender, straight, and weak; nostrils straight and linear; tongue pointed, slender; toes divided, or very slightly connected; back toe very small.

\section{Species 1.-The Snipe.}

The Snipe, or Snite, Wil. Orn. 290. Raii Syn. Av. 105. Scolopax Gallinago, Lin. Sys. 244. Brit. Zool. 358. Brit. Zool. Illus, tab.71. fig. 1. Orc. Myre-Snipe, Horsegok.

The Snipe continues with us the whole year; builds in the wet marshy hills, commonly in a tuft of rushes, where it lays from four to six (I have seen the latter number several times) eggs; in winter shifts as well as it can about the sea and spring-heads which are not frozen.

Though small, is very good eating, but seldom above one seen in one place.

In summer it makes an odd drumming noise in the air, which our country folks take for a sign of rain; at this time it is at a great height in the air, flying backwards and for- 
wards near the place of its nest; at other times its cry is a short shrill whistling; when hastily sprung, a hoarse scream.

\section{Species 2.-The Jack-Snipe.}

Gid, Jack-Snipe, and Judcock, Wil. Orn. 291. Raii Syn. Av. 105. Scolopax Gallinula, Lin. Sys. 224. Brit. Zool. 359. Brit. Zool. Illus. 71.

I NEVER saw above a couple of specimens of the jack-snipe in Orkney, nor do I think it a frequent bird.

The size distinguishes it from the former, as does the flight, which is shorter. But what points it out to every observer is the rump, which is of a fine purple, with a cast of blue, changeable in different lights; the bill is short, the half next the head pale flesh-colour, the point black.

It is found in marshy moors; is difficult to spring, and after fluttering a little about, claps into the nearest hole, or small spring, and lies close. I dare say it builds with us in season, as $I$ have seen it in summer.

\section{Species 3.-The Godwit.}

Godwit, Yarwhelp, or Yarwip, Wil. Orn. 290. Raii Syn. Av. 105. Scolopax Egocephala, Lin. Sys. 246. Brit. Zool. 351.

THIs bird I have very seldom observed in Orkney; is en- 
tirely a visitor. I have fallen in with small flocks of about a dozen, on our sandy shores in winter, where they feed with the curlew. It seems to be a stupid kind of bird; has nothing of the shyness of the curlew. I have shot several times at the flock, and after killing part, the others, after a small flight, would endure to be shot at several times immediately after.

The flesh is very delicate; seems the best tasted of all our shore birds, quite free from the rankness of some, and the fishy taste of others.

The Greenshank I have seen once on the burn-side of Birsay, in a stormy season, but do not take it to be an inhabitant of these isles, any more than the next-mentioned, but rather transient visitors. I have heard of one or two Woodcocks shot in Orkney, but they make us no regular visits that I can find. 


\section{GENUS XIX-SANDPIPERS.}

Gen.Char.-Bill straight, slender, and not an inch and a-lialf long; nostrils small; tongue slender; toes divided, generally the two outmost connected at bottom by a small membrane.

\section{Species 1.-The Lapwing.}

Lapwing, Bastard Plover, or Pewit, Wil. Orn. 307. Raii Syn. Av. 110. Tringa Vanellus, Lin. Sys. 248. Brit. Zool. 360. Sib. Scot. 19. Orc. Teewhoop.

ThE Lapwing is of those birds which, in a great measure, withdraw themselves from us in the winter season. I say in a great measure only, for I am informed by a clergyman, sometime minister of Sanda, they are to be found there in small numbers all winter. His words are; "I have seen them " in the months of November, December, and January, in " the bay of Otterswick, and all round the island. This " island lies low : is generally flat, and much warmer than " any of the others; almost all a sandy beach from the point " of Spurness, north and by west, to the bay of Stove, lying " south and by east, which is near' two-thirds of the circum"ference of the whole island." The lapwing is the most beautiful of the genus which frequent these shores. The head. is adorned with a fine black crest, erected when the bird walks, and depressed at other times; the head and bill black; the back and coverts of a most beautiful green, changing to 
purple; the lesser coverts have more of a blue cast ; the quills black, the ends of the four first marked with a white spot, the lesser ones half white and half black; the breast white, as is the belly; the tail has twelve feathers, the outmost white, with a dusky spot, the others white next the body, the other half black, tipt with white.

The legs red; the throat and part of the breast black, with white spots.

The lapwing is one of the most anxious creatures for its young of any wild-bird I know ; in breeding-time nothing frights it ; neither men nor dogs can terrify it from its haunts: though a very shy bird at other times, now it will strike at the head of the boldest invader, and, with vast clamour, defends its rights to the marsh. Linnæus says it drives away the ravens, who pick out the eyes of the lambs. I suppose it is perfectly sensible of the manners of the raven, that he often meddles with its own eggs and birds, and thus considers him as its own enemy.

The cry of the lapwing is plaintive, the same note (piwit) repeated; however, the male in breeding-time has another more cheerful note, which he repeats with great briskness when no danger is near, but when this threatens, he has the same plaintive cry as the female.

The lapwing breeds very early (as all the grallæ); I have seen their eggs in the beginning of April. It makes a nest on the bare heath, in a small hollow scraped by its own industry ; there it lays its eggs, which are four in number, of a dark olive-green, spotted with black, on the bare ground; but 
before it begins to hatch, lines the inside of the nest with bits of straw, bent, \&c. and this is often observed as a token whether the eggs are fresh or not, for when the nest is quite finished the incubation is pretty well advanced.

\section{Species 2.-The Redshank.}

Redshank, or Pool-Snipe, Wil. Orn. 299. Raii Syn. Av. 107. Brit. Zool. 368. Scolopax Calidris, Lin. Sys. 245. Brit.Zool. Illus.tab. 16. Sib. Scot. 19.

The Redshank never migrates; builds in the marshy hills in summer, and retires to the sea-shores in winter. When disturbed in summer, it flies about, making a faint noise, something like that of a lapwing; in winter it is found in the hollows of the sea-beach, among the mud and slime, where it lives upon sea-worms, and other insects. When any person comes in sight, it is immediately upon the wing, and disturbs every bird within hearing with its shrill screaming, so that it often gets the hatred of the fowler, and loses its own life for disappointing him of a better prey.

I have observed it in summer in the marshes of Ireland (a village so called), and in the wet hills between Kirkwall and Holm, and it is no doubt found in other such like places of the country. 


\section{Species 3.-The Turnstone.}

Tringa Interpres; T. pedibus rubris; corpore nigro, albo ferugineoque vario; pectore abdomineque albo, Lin. Sys.

The Tringa Interpres of Linnæus comes to us in hard snowy winters, when it may be shot, in small flocks of six or seven by the sea-side, but never stays our summer. Retires, I suppose, to Norway and other northern countries to build, with the other grallæ; a small part of those which visit us in winter, staying with us in summer.

\section{Species 4.-The Purre.}

The Stint, Will. Orn. 305. Stint, in Sussex the Ox-eye, Raii Syn. Av. 110. Tringa Cinclus, 251. Lin. Sys. Brit. Zool.374. Brit. Zool. Illus. tab. 16. fig. 1.

THIs bird is found in small flocks round our shores in winter, and in spring withdraws to the moors, where it breeds with the sea-larks; I have several times shot it with them in May or June, but never have seen its nest or eggs. 
Species 5.-The Dunlin.

Wil. Orn. 205. Raii Syn. Av. 109. Tringa Alpina, Lin. Sys. 249. Brit. Zool. 374.

Whether the Dunlin breeds in Orkney, I am unacquainted. We see it in small flocks through the winter, especially in our low sandy shores, but it withdraws in spring, probably to the marshy hills (though this I have never observed), to hatch.

\section{GENUS XX.-THE PLOVER KIND.}

Gen. Char.-Bill straight, as short as the head; nostrils linear; tongue; toes, wants the back-toe.

\section{Species 1.-The Green-Plover.}

Wil. Orn. 308. Raii Syn. Av. 111. Charadrius Pluvialis, Lin. Sys. 254 Brit. Zool. 379. Brit. Zool. Illus. tab. 72. fig. 2. (variety). Sib. Scot. 19. Orc. Plover.

Plovers are found here at all times of the year, and never entirely migrate ; however, the few that build in our hills are nothing to the myriads to be found here in winter, which 
surely come from some summer-haunt at a distance from us, and retire thither in the spring. Plovers begin to flock in July or August, (according as the season has been in spring that they could hatch early), and then possess the barest gravelly moors in thousands; continue thus till the winter. storms drive them down to the shores of the sea, where, as the rest of the waders, they live on insects and sea-worms.

Plovers are killed in great numbers in winter, on wing, while in the whirl, and one covers the other. They are very good eating, the best of the genus that frequent these isles, or indeed of the waders which are found in Orkney.

The variety with a black belly, mentioned in the British Zoology, is here called the male, but with what truth I cannot at present determine*.

\section{Species 2.-The Sea-Lark.}

Wil. Orn. 310. Raii Syn. Av. 112. Charadrius Hiaticula, Lin. Sys. 253. Brit. Zool. 383. Charadrius, the Sea-Lark, Sib. Scot. 19. Orc. Sand-lark, Sandy-Laverock.

THE Sand-lark is very common, especially in winter, when

* Since writing the above, I have minutely examined great numbers of plovers. In spring when the colours are most vivid, the cock's belly is a shining black, the hen's spotted black and dusky. The young do not acquire this mark till the second year. 
it is found in vast flocks round all the sandy bays of the country ; in summer retires to the bare brakes, where it builds a small nest on the ground, with straws and bent; lays four eggs, large for the bulk of the bird, of a whitish colour, with a few black spots sprinkled about the thicker end.

The crown of the head of this bird is of a brownish ashcolour; the face white; the cheeks, and a line from the bill to the eye, black; a fine white collar surrounds the upper part of the neck, immediately below which is a black one; the back is of the same colour with the crown of the head; the belly white; the legs yellow, with black claws.

In winter the sand-larks live on the very small worms which are everywhere to be found in the sea-sands ; and wherever there is a flock of them the whole sand is full of small holes, made by them in search of these, so that it looks as if pierced with numberless earth-worms. 


\section{GENUS XXI.-THE OYSTER-CATCHER.}

Gen. Char.-Bill long, compressed, the end cuneated; nostrils linear; tongue, scarce a third the length of the bill; toes, only three, the middle joined to the . exterior by a strong membrane.

\section{Species 1.-The Sea-Pie.}

Wil. Orn. 297. Raii Syn. Av. 105. Hæmatopus Ostralegus, Lin. Sys. 257. Brit. Zool. 376. Sib. Scot. 19. Orc. Sceolder.

Thrs bird is found on our rocky coasts, where it lives on the limpets, and other shell-fish. It continues with us the whole year, and builds here.

The bill is most excellently contrived to procure its living; it is long, strong, and compressed sidewise, so that if it finds a limpet but a little way from the rock, it easily insinuates its bill between the shell and the rock, and brings it off in a moment. If the limpet is on its guard, and more firmly fastened, it knocks it off as dextrously as any fisherman when he wants it to bait his line.

It is sometimes eaten, but the flesh is very wild, has much the taste of limpets, its food, which makes it not much sought after.

The colours of this bird, though few, are good, and their mixture produces a good effect. 'The head, neck, back, and part of the coverts are a fine full black, in some birds (cocks, 
I suppose), with a cast of green; the edges of the eyelids, and the irides, are a fine red ; part of the breast, the belly, and rump are white; the lower part of the tail is white, and the upper black. The quill-feathers are curiously marked with white from the three outermost, where it prevails least, but gradually encroaching, seizes the whole of the innermost; the legs and feet are flesh-coloured, rather clumsily made; the toes broad, and the outermost of these connected by a membrane, which is of excellent use to hinder these birds from sinking into the sand; the claws are dusky, short, and seemingly much worn by continually scrambling about the rocks in search of its limpet food.

The sea-pie is at very little pains about its nest; a hollow of the next rock, or between two stones, with an artificial hollow scraped by itself, lined with a few bits of grass, or sometimes with her own dung, serves the purpose. On this, or often on the bare rock, she lays four eggs, of an olive colour, spotted with darker blotches of the same. 


\section{GENUS XXII.-THE RAIL.}

Gen. Char.-Bill slender, a little compressed, and slightly incurvated; nostrils small; tongue rough at the end; body much compressed; tail very short.

\section{Species 1.-The Water-Rail.}

Water-Rail, Bilcock, or Brook-Ouzel, Wil. Orn. 314. Raii Syn. Av. 113. Rallus aquaticus, Lin. Sys. 262. Brit. Zool.385.tab.9. Brit.Zool. Illus. 74. fig. 1 .

Some time ago I had a bird of this kind sent me, but nobody could I get who had ever seen another of the kind, which makes me think it must be very seldom found here; where this one was caught, the sender did not inform me.

The weight was a little more than four ounces; the length, from the tip of the bill to the claws, near fourteen inches; the breadth sixteen ; the bill near two inches, furrowed, and a little crooked; the nostrils long, placed in the furrows ; the whole upper side of the body was a dark-brown, with a cast of black; the throat lead-coloured, as also the breast; the wings blackish ; the legs were pretty long, without the least rudiments of webs at the toes; these were placed farback; the tail short. 


\section{GENUS XXIII.-GALINULES, OR WATER-HENS.}

Gen. Char.-Bill thick at the base, sloping to the point, the upper mandible reaching far up the forehead, and not corneous; body compressed; wings short and concave ; toes long, divided to their origin; tail short.

\section{Species 1.-The Land-Rail.}

Rail, or Daker-Hen, Wil. Orn. 170. Raii Syn.Av.58. Corncreck, Sib. Scot. 16. Corn-Craker, Mart. West. Isles, 71. Rallus Crex, Lin. Sys. 261. Brit. Zool. 387. tab. 10. Brit. Zool. Illus. 74. Orc. Corn-Crake.

Thrs odd bird comes to us in the month of May or thereabouts, and continues till breeding-time be over. It conceals itself amongst long grass and corn; never cries, except when it is hid; lays a great number of eggs : 1 have frequently seen sixteen in a nest; the young run about when they are hatched; they are very ugly, covered with black hair.

The corn-crake is covered with long loosely-webbed feathers; the colour of the back a bay mixed with black; the wings in harvest become a very deep bay, inclining to red; the tail is short, and much of the same colour.

The corn-crake has not a strong wing; never flies far while here, and the little it does is very awkwardly performed, with the legs hanging down; and yet, what is remarkable, this is a migratory bird, and must surely take long stages on these occasions. I know not whether many of them may perhaps 
perish in these migrations, which may thin the breed, as I know very few enemies they have, and the number of their young is great.

The order of migration in this bird is to me unknown: I never could observe them going off in flocks, like the lapwings, swallows, \&c. nor do they convene in order to settle matters beforehand, as these have been observed to do.

\section{Species 2.-The Water-Hen.}

Common Water-Hen, or Moor-Hen, Wil. Orn. 312. Raii Syn. Av. 112. Fulica Chloropus, Lin.Sys. 258. Brit. Zool.388. Brit.Zool. Illus.tab. 76. fig. 1. Sib. Scot. 19.

Thrs species, I am informed, is found in a large loch at the house of Aikerness, in the parish of Evie, where it builds its nest among the weeds of which that loch is full. I have never seen it; but, by Mr Pennant's description, it is a beautiful bird, especially the male, the plumage of which has a fine olive gloss. It builds several times a-year ; drives away its young when they are able to shift for themselves; lays seven eggs, of a dirty white, thinly spotted with rust-colour. 


\section{ORDER VII.-WITH PINNATED FEET.}

\section{GENUS XXIV.-PHALAROPE.}

Gen. Char.-Bill strait, slender; nostrils minute; tongue, body, and legs in every respect like the sandpipers.

\section{Species 1.-The Red Scollop-toed Sandpiper.}

Mr Johnson's small cloven-footed Gull, Wil. Orn. 355. Larus fidipes alter nostras, Raii Syn. Av. 132. Tringa hyperborea, Lin. Sys. 249. Brit. Zool. 391. Brit. Zool. Illus. 67. tab. 75.

ThIs bird I have never scen, but am informed it is sometimes met with in the Orkneys. $\mathrm{Mr}$ Pennant takes notice of one shot in Stronsay in 1769. I have heard of several other examples, but have never yet had the good fortune to meet with one. The following description of this bird is from the British Zoology:-

"It is the size of a purre; bill an inch long, straight to near "s the end, which bends a little downwards; crown of the " head, hind part of the neck, back, scapulars, and coverts " of the wings, of a deep lead-colour; the back and scapulars " stripped with a dirty yellow; across the greater coverts is

- " a line of white; throat white; under part and sides of the 
" neck of a bright ferrugineous; breast of a deep cinereous ;

" belly white; tail short and cinereous; legs black; the toes

" not webbed together, but bordered on each side with late" ral membranes, scolloped and elegantly serrated."-Vol.IV. p. 67 .

\section{GENUS XXV.-THE GREBE KIND.}

Gen. Char.-Bill strong, slender, sharp-pointed; nostrils linear; tongue slightly cloven at the end; body depressed; feathers thick set, compact, and very smooth and glossy; tail, none; wings short ; legs placed very far behind, very thin, or much compressed, doubly serrated behind; toes furnished on each side with a broad plain membrane.

Species 1.-The White and Dusky Grebe.

Brit. Zool. 397. Brit. Zool. 1llus.tab. 17. fig. 1*.

THIs is the only species of Grebe I know of, an inhabitant of the Orkneys. It is found in our bays, lochs, and puddles of fresh-water, at all times of the year; builds in the grassy loch of Aikerness with the water-hen; makes its nest among the weeds. Stays all seasons; builds with us.

The bill, in two specimens I lately examined, was about an inch long, strong, and sharp ; the head small, and covered

* Called in South Ronaldsha little footy-arse. 
[Birds.

with dusky feathers; the back and whole upper side of the body was an uniform dusky-black; the throat and breast bay ; the feathers of the cheeks remarkably full ; the belly silvercoloured, insomuch that that part looked like a piece of fine white satin; it had no tail, instead of it were two or three small feathers without webs; the feet were placed very far back; the legs thin; the toes divided into lobes; the claws broad, something resembling those of the fingers of the human body.

It can fly, but is not easily raised from the water; dives most excellently, continuing a long while under water; and if it is frighted, or dreads danger, sets up nothing more but its head and part of its small neck.

I once shot a bird of this kind in the Orkneys, which I took for the "Colymbus Podiceps,"-Lin. Sys. 223, but am persuaded since it was but a younger bird of this species.

These are found in the sea, as well as in fresh waters.

Linnæus tell us this species makes its nest amongst the reeds, which Mr Pennant confirms of another of the same genus, which often floats clear of them into the lake, when the owner is said to steer it with its feet, which pass through it.

The bird above described lives on fish, and is perpetually diving in search of these ; perhaps, like its congeners, it can feed too on water-plants. How many eggs it lays I cannot say, having never seen the nest. 


\section{ORDER VIII.-WEB-FOOTED BIRDS.}

\section{GENUS XXVI.-THE AUK KIND.}

Gen. Char.-Bill strong, thick, convex, compressed ; nostrils linear, placed near the edge of the mandible; tongue almost as long as the bill; toes, no back toe.

* Those with thick bills.
** Those with slender bills.

*

Species 1.-The Auk.

Razorbill, Auk, Murre, Wil. Orn. 323. Raii Syn.Av. 119. The Marrot, Sib. Hist. Fife, 48. Alca Torda, Lin. Syst. 210. Brit. Zool. 403. Brit.Zool. Illus.tab. 19. fig. 2. Orc. Baukie.

These birds are very common in all the headlands and high rocks round the country ; they come here in March, and fill the whole shelves of the rocks in breeding-time; lay but one large egg, either on the bare rock, or I have seen them, where there was any earth in the interstices, make a small hollow, wherein they placed their single egg; but this is seldom, and when it is the case they take no pains to line it 
with any soft materials as other birds : but it is more ordinary with them to place their egg on the bare shelf of the rock, where, no doubt, the heat of the sun beating on it, and reflected from the rock, is greatly assisting to hatch it.

The description of those I had from Hoy-head is as follows: The length eighteen inches, the breadth twenty-six; the weight twenty-four ounces; the bill strong, sharp, and cutting, straight to the point, when both mandibles crook a little downwards, but the uppermost is much compressed, and the upper mandible is crossed by four transverse grooves, the lower with three, the broadest of which is a white, and crosses both ; the inside of the mouth a fine pale yellow; the bill runs pretty far up, and at the angle begins a narrow white line, which runs to each eye; the gape of the mouth is wide, and where the feathers begin the bill is as it were bordered ; the head, part of the throat, the whole upper side of the body (except the points of the lesser quill-feathers of the wings, which are white, and form a white stripe) is black; the tail consists of pointed feathers, which are often much wore by the birds sitting on the rocks; the whole under side of the body, as also the insides of the wings, is white; the legs and feet are black, and webbed to the claws.

Both birds and eggs are eaten by our country people, who venture over the most dreadful precipices for them; the latter, eaten with salt, pepper, and vinegar, are very good, but the flesh of the birds themselves is rank and fishy tasted. 


\section{Species 2.-The Puffin.}

Puffin, Coultermeb, Wil. Orn. 325. Raii Syn. Av. 120. Alca Artica, I,ini. Sys. 211. Anas arctica Clusii, Sil. Scot. 20. tab. 16. fig. 1. Brit. Zool. 405. Coulterneb, Mart. West. Isles, 25.? Avis narina Sea Coulter dicta, Sib. Scot.22.? Orc. Tommy-noddy, Tommy.

Found very frequent with congenerous birds in our rocks ; builds its nest under ground ; like the others lays but one egg. The dimensions of those found in Hoy-head are the following: Length twelve inches, breadth twenty-two, weight thirteen ounces ; the bill is much compressed, with three furrows, the fore-part of it is red, parted with a white line from a grayish root, which runs up the forehead, forming a ridge and a very sharp angle ; the root of the bill is encompassed with a narrow whitish-coloured skin, pierced full of small holes or points; at the corner of each jaw is a piece of naked yellow skin ; the nostrils are long and narrow, looking downwards; the eyes are fine, sparkling, and sharp while alive, the irides dusky, and the edges of the eyelids red; on the eyelids are two odd naked callosities, which together form a triangle, as the upper one is of itself, the like not to be found in any other bird round these isles which has come to my knowledge*. Both

* I just now have a bird of this species in my possession, which weighs halfa-pound: wants the callosities at the eyelids, and the narrow rim round the bill. This was found drove on shore, Dec. 20. 1775. In other respects it differs not from the above description. 
the cheeks and round the eyes are gray, under the chin a little darker; from the eyes runs a remarkable parting of the feaihers, very visible while the bird is alive, but soon obliteraten when it is dead; the top of the head, whole upper side of the body, wings, and tail, are black, with a collar of the same round the neck; the breast and belly white; the inside of the wings dusky; the legs and feet are yellow, with black claws, the innermost of which is much hooked; the tail short and rounded.

- This, too, is one of the birds for which our rock-men venture life and limbs. The flesh is very rank and fishy tasted. It takes flight with great difficulty, and is often run down with boats, but can fly very well when it once gets wing. Our people take these from their holes with a stick, at the point of which is an iron hook ; but they must take great care both of this and the former, for they bite very severely, and the form of the bill makes the impression still more strong.

I have observed many of this species drove ashore in a sudden storm, that is, when caught suddenly in a gale of wind, which is a further proof of the difficulty they have to take wing from a level; indeed, all the motions of the sea-birds, except swimming, are extremely awkward. 


\section{Species 3.-The Little Auk.}

Little Black Auk, Black and White Diver, Wil. Orn. 343. Raii Syn. Av. 125. Alca Alle, Lin. Sys. 211. Brit. Zoøl. Illust.tab. 19. fig. 1. Var.

THIs bird I met with preserved in a small colleçtion belonging to a young lady in this country, and am informed it is to be found pretty frequent round the rocks.

The bill was but little compressed, thick, short and strong, pretty much of the shape of that of the grosbeaks ; its colour black. Like the rest of the genus the whole upper side was black; the throat and belly white; the sides of the neck white, spotted with black; the legs covered with whitish scales; the webs in that I saw white. The dimensions I could not take, nor the weight, as it was a stuffed skin I took these notes from 


\section{GENUS XXVII.-THE GUILLEMOTE.}

\section{**}

Gen. Char.-Bill slender, strong, pointed, the upper mandible slightly bending towards the end, base covered with short feathers; nostrils lodged in a hollow near the base ; tongue slender, almost the length of the bill ; toes, no back toe.

\section{Species 1.-The Guillemote.}

Guillem, Guillemot, Skout, Kiddaw, or Sea-Hen, Wil. Orn.324. Raii Syn.Av. 120. Colymbus Troile, Lin. Sys. 220. Brit. Zool.410. Orc. Skout.

THIs bird is found with its neighbours in the rocks in great flocks. Like the rest of this kind they lay but one egg, but this is very large and beautiful.

Those I had brought me from Hoy-head agreed with $\mathrm{Mr}$ Pennant's description in every particular, only those I found to be cocks were of a deeper black and clearer white than the others, or females.

Our rock-men catch vast numbers of these, and salt them for winter or summer provision, but they are all very rank and fishy. Mr Pennant says they are very simple birds, and though shot at, or see their companions drop beside them, they will not quit their station on the rock*.

* Since writing the above, I have seen several instances of their stupidity in 
Species 2.-The Black Guillemote.

Greenland Dove, or Sea-Turtle, Wil. Orn. 326. Raii Syn. Av. 121. 'Turtur' Maritimus insulz Bass, Sib. Hist. Fife, 46. Colymbus Grylle, Lin. Syst. 220. Brit. Zool. 412. Brit. Znol. Illus.tab. 20. fig. 2. Columba Groenlandica, the Sea Turtle-Dove, Sib. Scot. 20. Orc.*'Taisté. Toisté, Wallace.

This Guillemote differs in its history from the rest ; they all go off from us in the winter season, leaving our rocks bare and barren, but this keeps constantly with us for the whole year, continually to be found in our sounds, fishing all weathers.

The length of this species is fifteen inches and a half, breadth twenty-two, weight ounces; the bill is slender, but strong and sharp, the colour black; the whole inside of the mouth of a deep orange-red; the whole plumage is black, except the speculum of the wing and the inner coverts, with a very small spot under each eye, which are all white. In this, as well as all the water-fowl, the feathers are very thick and close, always damp with the quantity of oil which the bird takes care to anoint them with, to keep off the cold and water. This gives the feathers a very rank smell, and makes them unfit for the purposes of bedding, for which they would

allowing themselves to come so near the boats, as to be knocked down with an oar or boat-hook. They continue in Orkney throughout the winter.

* Avis parva prepinguis in Orcadibus Tyst dicta._Vide Sib. Scot. 22 . 
otherwise be excellent; but these are invincible obstacles to their being used to these purposes, as no method has yet been hit upon to clear them from the smell and dampness.

The taisté build in holes of the earth ; like the rest lays but one egg.

These birds are found in the winter-time almost wholly gray, and others spotted about the head, neck, and back, with that colour; but whether they change colour in winter, and put on this as the dress of the season, or if it is the last year's brood not yet arrived at their proper colours, I am uncertain ; one thing I am certain of, that I have seen them of both colours late in the winter, and early in the spring, so that, in my opinion, the change is not universal, or perhaps it is but in the hardest winters where this happens in general *.

Before I dismiss this genus, I must take notice of one particular which $I$ have often observed, and no doubt has been so by others before now, and this is, that all these birds make use of their wings below water in the same manner as a swimmer uses his arms, the strokes of which answer to those of his legs ; just so the auk, the puffin, the guillemotes, and no doubt the divers use their wings, the strokes of which exactly correspond with those of their feet, and by this means make vast

* The following particular makes me imagine it the young brood that are thus coloured : The legs and feet of the speckled individuals are of a dirty brown. whereas the old birds have these uniformly a very deep orange; and I believe it is yet unobserved, that birds having once acquired their growth and colours, ever change these of their bare parts. 
way in the water, and no doubt are of great service to them in their ascent from the bottom, as these are not furnishcd with an apparatus for this purpose like the fishes; but however this is, the above may be easily observed by any one upon throwing a stone over the rock where they haunt, when he will see those that dive striking alternately with wings and legs, till the depth of water hides them from his sight.

Whether any other species of this genus ever appear on our coasts, I am uncertain ; have never observed any other; have often inquired about the Great Auk especially, but cannot find it is ever seen here; nor can I find the Black-billed Auk, nor the Lesser Guillemote.

'These birds, except the taisté *, all retire from us in winter, and come again in spring. The country people say they keep to a day almost in their exits and returns; however, this, I dare say, depends much upon the weather, as is the case with the migration of the wans, the nestling of small birds, and the springing, leafing, and blowing of plants.

It is from these things the universal almanack is to be drawn, and from these many of our rural observers will draw as certain notions, as the greatest philosophers with all their learning.

\footnotetext{
* And the Scout or Guillemote.-See the note, p. 104.
} 


\section{GENUS XXVIII.-THE DIVER.}

Gen. Char.-Bill strong, straight, pointed, upper mandible the longest, edges of each bending inwards; nostrils linear, the upper part divided by a small cutaneous appendage ; tongue long and pointed, serrated at each side near the base; legs very thin and flat; toes, the exterior the longest, the back toe smull, joined to the interior by a small membrane; tail short, consists of twenty feathers.

\section{Species 1.-The Great Northern Diver.}

Wil. Orn. 342. Raii Syn. Av. 125. Colymbus Maximus stellatus nostras, Sib. Scot. 20. tab. 15. C. glacialis, Lin. Sys. 221. Brit. Zool.413.

The Great Northern Diver is very frequent round all the Orkneys, but especially in the bays and harbours, which it enters in pursuit of small fish, its only sustenance. The natural history of this and the following species is something paradoxical. Though they continue among these islands the whole season, 1 can find none to inform me how or where they breed. It is certain the formation of their legs, and the manner of placing them, does not allow them to walk, nor will teasing make them fly, as I have often seen ; indeed, their wings seem too small for this purpose. How then do they propagate and hatch? 'To solve this many improbable schemes have been advanced ; some* telling us "they have their nests and

* The elder Wallace, Hist. Ork. 16. ed. 1693, and from him transmitted to Sir Robert Sibbald. 
" hatch their eggs under the water;" others, that they do this in a natural hollow under their wings, and that they have but a single egg. How it is, I confess myself ignorant, nor can $\mathrm{I}$, as far as $\mathrm{I} \mathrm{know}$, in this particular be informed by the writings of the naturalists, none of whom that I can learn adverting to this bird's inability to perform its functions in the ordinary way.

This is the largest diver we have, in length three feet and a half, breadth four feet eight inches, weight sixteen pounds. The head and neck to the breast are of a deep black, with a gloss of green, changeable into purple; under the throat is a small semilunar white band, streaked with black, and on the neck behind a larger, streaked in the same manner ; the bill is black, sharp, and strongly made; the breast and belly, also the under sides of the wings, pure white; the sides of the breast, to the setting on of the wings, curiously streaked black and white ; the back, coverts of the wings, and a stroke under the wings, along the sides, are black, but each feather marked with two well defined white spots; the scapulars are long, and the spots large and square; the tail short and black; a dusky line runs from the thighs to the vent; the legs are black.

I take this or the next to be Martin's carrara, bonnivochil, or bishop-fowl, which he describes " to be as big as a goose, " having a white spot on the breast, and the rest party-colour" ed; it seldom flies, but is exceeding quick in diving;" weighs, according to him, sixteen pounds one ounce.-Vide Descrip. West. Isles, page 72. 


\section{Species 2.-The Immer.}

C. pedibus palmatis tetradactylis, corpore supra nigricante albo undulato, subtus toto albo, Brunnich. Orn. 129. Lin. Sys. 222. Anser nostratibus the Ember-goose dictus, Sib.Scot. 21. Emmer or Immer Goose, Orc.

Tirs species, by common observers, is not distinguished from the last, but both go in Orkney under the name of Immer or Emmer Goose; they are, however, very different. Sir Robert Sibbald places it among his goose or duck-kind with broad bills, between the wild and dunter-goose (anas molissima), but it has nothing to do in the genus. The emmergoose is very frequent in our sounds and bays at all seasons. Like the former it never attempts to fly, even though fired at ; seems to put its whole trust in diving, which it does with wonderful facility, stays a long while under water, and rises at a vast distance. In bulk it equals the former; the bill strongly made, very sharp, and four inches long, the ridge of the upper mandible black, the rest both of $t$ and the lower palccoloured; the head and neck a dusky black; the throat, belly, and inside of the wings white, with a blackish line crossing the vent ; the whole upper side of the body is a dusky black, only the point of every feather is bordered with white, which at some distance looks as if it were waved; the covert feathers of the wings, instead of white, are waved with a faint ash-colour, the quill-feathers black; the legs, like all those of the tribe, are thin, and partly white and part black; the tail 
short, and, like the back, party-coloured, tipped with a dirty white. Like the former, the time, place, and manner of building of this bird is to me unknown. The same story* is told of its hatching under water, but this, in all probability, is a refuge for ignorance, as most marvellous stories are. It utters a howling cry much like that of dogs ; is very hard to shoot, as it dives immediately on the flash from the gun-pan. Like most sea-birds, this is very fat, having near an inch deep of fat on the skin, which both makes it difficult to be gotten off, and more so to dry.

\section{Species 3.-The Gray Speckled Diver.}

Greatest Speckled Diver, or Loon, Wil. Orn. 341. Raii Syn. Av. 125. Brit. zool. 414. Orc. Loon.

Tris is the least of the greater divers which frequent these shores; it only appears here in the winter season, and goes off in spring, but where it retires to I cannol say; probably to the northern countries, where it will be less disturbed in breeding-time than here.

It is to be found constantly in the winter season in the bays and sounds, but in no place more frequently than the harbour of Stromness, where it constantly attends the shoals of coal-

* Anser qui nidulari sub aqua, et suba qua etiam ovis incubare traditur.-Vide Sib. Scot. 21 . 
fish fry which set in there, amongst which it makes great havock.

Those birds differ much in their spots, some being more and some less spotted, likewise in the placing of these ; in general the head is gray, spotted with white, the whole upper part of the body spotted with the same; the tail black, spotted with white; the whole under side white, as all the divers are, to a bird, which have come to my knowledge; all have white bellies, except some of the gulls and ducks, but these can scarce be called divers : the first seldom dive, and the ducks are so differently formed, that it is impossible to rank them with these.

\section{Species 4.-The Red-throated Diver.}

Northern Douker, Wil. Orn. 343. Raii Syn. Av. 125. Colymbus septentrionalis, C. arcticus, Lin. Sys. 220, 221. Brit. Zool.415. Brit. Zool. Illus. tab.21. fig. 1, 2. Orc. Rain-goose.

THE Ra in-goose, as it is here called, continues with us the whole season; builds on the very edge of a lake in the hills of Hoy; lays two eggs; its nest placed so as it can slip from it into the water, as it can neither stand nor walk at land, but can make very quick way in the water; flies well, and commonly very high : makes a vast howling, and sometimes croaking noise, which our country folks say prognosticates rain, whence its name, with the addition of goose; and here it is 
worth while to remark anent the provincial names of birds, every large swimming bird is called goose, with some other distinguishing epithet, thus, ember-goose for the great-diver, dunter-goose for the eider-duck, rain-goose for the above, \&c.

The male and female of this species are constant companions. I have observed this whole season a couple of them which build in Hoy, and have made the harbour of Stromness their haunt, to come every night thither about six or seven o'clock, seldom sooner or later, and immediately betake themselves to fishing for about an hour, when they withdraw to the same place they came from. These birds have a vast liking to one another ; if one is shot, the other may be seen hovering about the place for some days, and, often venturing too near in its search, shares the same fate. It is then very pitiful to consider the wistful looks the survivor casts around it, to see for its faithful mate, and with what anxiety it swims round and round, still keeping its eye on the place where it was taken on shore ; but this is in some measure to be observed in others of the swimming birds in breeding-time, though not so much as in this; however, I have observed a male goosander, when the female was shot, continue a long while near the same place, probably still expecting his mate.

This is a very beautiful bird; the male has his head adorned with fine stripes of dusky and white, which run down his neck alternately; the back a dusky gray; the wings spotted with white, these are small, sharp, and placed far back on the body; the throat reddish; the belly white; the feetplaced far back; the legs thin like the back of a knife, good for nothing at land, 
but excellently fitted for swimming; the feet, when the stroke is given, extend to their whole breadth, but when it is to be fetched these fold up and become little thicker than the leg. All parts of these birds are excellently fitted for making their way through the water with great speed; the head is taper, the bill small, \&c. but this is so excellently described by the pious author of the Wisdom of God in the Creation, that I shall give it in his own words:- " The bodies of the colymbi, " duckers, or loons, are admirably fitted and conformed for " diving under water, being covered with very thick plumage, " and the superficies of their feathers so smooth and slippery, * that the water cannot penetrate or moisten them, whereby " their bodies are defended from the cold, the water being ". kept at a distance, and so poised that by a light impulse ". they may easily ascend in it ; then their feet are situated in " the hindmost part of the body, whereby they are enabled, " shooting their feet backwards, and striking the water up"6. wards, to plunge themselves down into it with great facility, " and likewise to move forwards therein; then their legs are "s made flat and broad, and their feet cloven into toes, with " appendant membranes on each side, by which configura" tion they easily cut the water, and are drawn forward, and " so take their stroke backwards ; and besides, I conceive, " that by means of this figure, their feet being moved to the " right and left hand, serve them as a rudder to enable them " to turn under water, for some conceive that they swim " easier under water than they do above it. How they " raise themselves up again, whether their bodies emerge of 
" themselves by their lightness, or whether by striking against " the bottom in the manner of a leap, or by some peculiar " motion of their legs, I cannot determine. That they dive " to the bottom is clear, for that in the stomachs, both of the " greater and lesser kind, we have found both grass and other " weeds, and in the lesser kind nothing else, though both prey " upon fish. Their bills are made strait and sharp, for the " easier cutting the water, and striking their prey. Could " we see the motions of their legs and feet in the water, then " we should better comprehend how they ascend, descend, " and move to and fro, and discern how wisely and artifici" ally their membranes are formed and adapted to those “ uses."-Vide Ray's Wisd. of God.

It is probable they easily rise from the bottom, by their bodies being specifically lighter than the water; and, as a proof of this, I have often observed them labour much more in going down than coming up; both wings and legs were exerted to the utmost, but when they rose both seemed at rest. 


\section{GENUS XXIX.-THE GULL-KIND.}

Gen. Char.-Bill strong, straight, but bending down at the point, on the under part of the lower mandible an angular prominency ; nostrils oblong and narrow, placed in the middle of the bill; tongue a little cloven; body light ; wings long; legs small, and naked above the knees; back toe small.

\section{Species 1.-The Great Black and White Gull.}

Wil. Orn. 344. Raii Syn. Av. 127. Larus marinus, Lin. Sys. 225. Brit. Zool.416. Sib.Scot. 20. Orc. Blackbacked-Maw, Swartback.

TiIs is the largest of the gull-kind which is found in these seas, or round the whole country. It continues here the whole year; builds on the insulated rocks round the shores, and sometimes on the shelves. It is very ravenous, as much so as an eagle, only it meddles not with lambs or poultry, but for carrion and garbage none is more so. It beats away the smaller gulls from any fish which may happen to be thrown ashore, and seizes the whole prey to itself; but if it misses of this, sits down contentedly to a piece of dead horse if it can get it.

In bulk it almost equals a goose ; the length, from the point of the bill to the end of the tail, two feet three inches, but if measured to the claws it is two feet five; when the wings are extended it is five feet three inches from tip to tip. The beak of one I measured was something more than three inches long, very strong, and much hooked at the point; on the 
the lower mandible is a large angular knob, which is black towards the opening of the mouth, but reddish below, the colour of the rest of the bill was a pale yellow; the nostrils were long, and broadest toward the point of the bill; the head was large, and on the crown a few ash-coloured spots; the neck to the shoulders, the breast, and belly white; the back and wings black; the quill feathers were all tipt with white; the rump white, with twelve spotted feathers in the tail; the legs were bare above the knee for a small space, as in the others of thie kind, of a pale flesh-colour inclining to white; the claws black.

I never saw its egg, but Mr Pennant tells us it is very blunt at each end, of a dusky-olive colour, quite black at the greater end, and the rest of it thinly marked with dusky spots.

I know not if there is any variety with red feet which Linnæus describes his with; mine, too, had a few ash-coloured spots on the head which Mr Pennant's has not, but this might have been owing to difference of sex or age, as there is no genus of birds perhaps which passes through more changes of colour than the gull-kind, which seldom arrive at their colour the first year: 


\section{Species 2.-The Arctic Gull.}

Brit. Zool. 420. Brit. Zool. Illus. 35. tab. 22. Faskidar, Mart.West. Isles, 73. Larus parasiticus, Lin.Sys.226. Orc. Scouti-Aulin.

Turs is a migratory bird, comes in May and departs with the sea-swallow, or great tern. I suppose it builds with the rest of the tribe in the rocks *, though I never saw its nest, but it continues here the whole breeding-time.

It seems this gull can make little shift for itself, being hindered by some natural defect or laziness, for it always makes the others its providers. It is most commonly on the wing, and wherever it sees a flock of others a-fishing, it hovers about till it sees something caught, upon which it immediately sets out in chace of the captor, and never leaves tormenting it till it drops the prey, which the other always catches before it reaches the water. Even when it has it in its stomach it is not safe, for all the gulls, upon being frightened or teased, are apt to throw up what is in their stomachs, which I have often seen upon shooting a gull ; it would vomit up a quantity of worms or whatever else was in its belly. The parasitic gull is acquainted with this, and if he misses prey the other way, torments the first he can get on, till in this manner he receives the fruit of his toil ; but notwithstanding the opinion of many

* It builds in moorish grounds, and among heath, with the lapwing and the snipe. Author. 
very eminent natural historians, I cannot think the excrement of one congenerous bird can be the food of another; but this is only a private opinion.

\section{Species 3.-The Skua.}

Our Cataracta, I suppose the Cornish Gannet, Wil. Orn. 348. Ruii Syn. Av. 128. Cataractes, Sib. Scot. tab. 14. Sea Eagle, Hist. Fife, 46. Larus Cataractes, Lin. Sys. 226. Brit. Zool.417. Foula, Bonxie.

Tuis Gull we have not in Orkney, neither had I ever an opportunity of seeing it till last summer I met with it in Foula, an island to the westward of the Shetland Isles.

As I approached the summits of the high mountains, I came near the skua's quarters, which are affixed on the very peaks. I no sooner approached but I was attacked with so greal fury, that every one of those who were with me, as well as myself, were obliged to do him obeisance at every stroke. He beat my dog entirely out of the pit, insomuch that he was obliged to run in among our legs for shelter, and could not be forced out again, for though bonxie (as he is here called), had some regard for us while we kept together, on him he had no mercy, every whip he fetched him made his own wings crack, and the dog crouch into the hollows of the moor, till we came up and relieved him. I followed one of them to some distance from the rest, which made me part good company, and received some very rude salutes for my imprudence 
$[$ Birds.

from three of these birds that made at me with the utmost rage. I defended myself the best way I could with my gun, fired several times at them, but, as none dropped, the report did not startle them in the least, rather seemed to enrage them the more. When the inhabitants are looking after their sheep on the hills, the skua often attacks them in such a manner that they are obliged to defend themselves with cudgels held above their heads, on which it often kills itself.

The method of life is much the same as in the parasitic gull (our former species), only this attacks the larger kind of gulls as the other does the lesser. By the most minute inquiry, could not find that it ever meddled either with its congeners or others to destroy them. Its fury seems to be more defensive than offensive. When we meet it at sea it seems to be a stupid like bird, and often swims. within an oar's length of the boat.

In Foula this is a privileged bird, no man will nor dare shoot it, under the penalty of sixteen shillings and eightpence sterling, nor destroy its eggs. When they meet it at sea whatever fish they have in the boat skua always get a share, and all this out of gratitude for beating off the eagle, who dares notventure to prey on the island during the breeding season. Skua, indeed, is not so strong as the former, but much more nimble, strikes at him without mercy with such effect that he makes the eagle roar aloud, and his retreat is so sudden as to avoid all danger from his clumsier antagonist.

I asked particularly whether skua did not sometimes pay himself for defending their flocks, by taking a lamb now and 
then, but one and all assured me they had never seen or heard of a single instance of his doing so.

The description of this bird in the British Zoology is pretty good. The neck is much thicker and stronger than in other gulls; the wings reach near the point of the tail ; the tail, when flying, is spread like a fan, has no long feathers like the arctic gull; the cry is hoarse and strong; lays two eggs in the heath of the highest hills, much of the same colour as those of the arctic gull, of an olive colour, blotched with darker spots of the same; it. weighs three pounds four drachms; length, from the point of the bill to the point of the tail, two feet; breadth four feet and a half; the bill two inches and a quarter, black, strong, and crooked, the base covered with a sort of horny substance; the legs black, webs the same; the talons strong and crooked, especially the innermost, but nothing near equal to those of the smaller birds of prey ; the general colour of the upper side of this bird is a rusty-brown the head, breast, and belly lighter; the quills black towards the upper part, but white towards the wing, which appearing when the bird is on wing forms a white spot : the tail consists of twelve dusky feathers with white roots. 


\section{Species 4.-The Herring-Gull.}

Will. Orn. 345. Raii Syn. Av. 127. Larus fuscus, Lin. Sys. 225. Brit. Zool. 421. Brit. Zool. Illus. tab. 79. fig. 1.

THE Herring-Gull is found in great numbers in all the rocks of these isles, but in none in greater numbers than in one called the Black-Craig, in which the nests are placed as thick as they can stand on the shelves. These are very large, made of dried grass heaped together, in which it lays its eggs, commonly three in number.

The young birds of most of the gulls are good eating, and sought after by our rock-men, as well as the eggs of every rock-fowl.

\section{Species 5.-The Brozon and White Gull.}

Great Gray Gull, the Cornish Wagel, Wil.Orn.349. Raii Syn. Av. 130. Larus Nævius, Lin. Sys. 225. Brit. Zool. 422. Brit. Zool. Illus. tab.79. fig. 2. Orc. Scory.

This is the scarcest of the Gull-kind in Orkney, however, it is pretty frequent: commonly seen in the fields in the spring, faithfully attending the swine, with whom it shares the prey which they root for, such as earth-worms, \&c. The colour of this is different from any of the rest, being mottled 
with black, brown, and dirty white ; the larger feathers black ; the bill black; the legs of a dirty white; but the colour of the bill is a distinguishing mark in this from all the rest of the gull-kind which are found here.

\section{Species 6.-The Common Gull.}

Common Sea-Mall, Wil.Orn. 345. Common Sea-Mall, or Mew, Raii Syn. Av. 127. Larus Canus, Lin. Sys. 224. Brit.Zool. 424. Brit. Zool. Illus. 23. Orc. White Maw, Sea-Maw.

These are found everywhere; fill the rocks, bays, and harbours in summer, in such a manner as to deafen one with the clang which is among these and others; so well known as to need no description.

\section{Species 7.-The Tarrock.}

Wil. Orn. 346. Raii Syn. Av. 128. Larus tridactylus, Lin, Sys. 224. Brit. Zool.425. Brit. Zool. Illus. 26. tab. 23. Sib. Scot. tab. 16. fig. 2. Orc. Kittiwake.

TH Is is the most frequent of the kind in Orkney; cover the whole rocks in summer that at a great distance they appear white with them; they sit in tiers over one another, as thick as one can press to one another; often appear at the face of 
these precipices like a cloud, and fill the air with their cry, which is the word kittizeake often repeated, whence the name.

The colours of this, as well as the rest, differ much according to age, sex, and I think season, sometimes spotted and blotched about the wings and head with black; however, an old bird has the whole body, except the back and wings, white; the latter gray, the tips of the five first quill feathers black, with a white spot ; the legs dusky, with only three toes ; the back toe wanting, and only a knob in its place.

These birds are much sought after in many places for eating, and the young are said to be tolerable, but all the gullkind are wild and fishy tasted.

\section{Species 8.-The Perwit Gull.}

Pewit or Black-Cap, Sea-Crow, Mire-Crow, Wil. Orn. 347. Raii Syn. Av. 128. Larus ridibundus, Lin. Sys. 225. Brit. Zool. 426. Orc. HoodedCrow.

THIs species is pretty frequent with us in spring, and I have seen a few in summer. It is probable they build on the grassy holms in the lochs, such as Stenness, Evie, \&c. but I never saw any of these.

This is easily known from all the rest by its head, bill, and legs; the head in some is black, in others a dusky brown; 
the bill and legs red; the breast, belly, and tail white; back and wings ash-coloured.

These are the gulls I have observed in Orkney, and I think we have few more, perhaps the Winter-Merw, (Brit. Zool. 423), but I have never had an opportunity to examine that species.-The* Skua and Cepphus, for ought I can hear, are not to be found here.

\section{GENUS XXX.-THE TERN.}

Gen. Char.-Bill straight, slender, pointed; nostrils linear; tongue slender and sharp ; wings very long; toes, a small back toe; tail forked.

\section{Species 1.-The Greater Tern.}

The Sea-Swallow, Wil. Orn. 352. Raii Syn. Av. 131. Sterna Hirundo, Lin.

Sys. 227. Brit. Zool.428. Brit. Zool. Illus.tab. 81. fig. 2. Orc. Rittock.

THIs bird only appears here in summer, and leaves us in winter; it comes in May, and departs when breeding-time is over.

The bill is red ; the crown of the head black; the underside of the body white; the back and wings approaching to

* It is found in Shetland.-Vide the Article. 
[Birds.

ash-colour ; the wings are long, and reach near the point of the tail, which is very much forked; the feet are small, and of a fine red colour.

These build in vast numbers in the uninhabited isles of Orkney, and in the holms of the lakes; are seen in vast numbers all along the sea-side, and edges of the lakes, fishing; they hover a little over the water, and suddenly dart down on any small fish they observe. This bird may be said to be the arctic gull's provider, for no sooner does it catch a small fish but it utters a particular cry, which the other (who is commonly on the watch) no sooner hears, but he immediately pursues and forces it to drop the prey, which he as nimbly catches ; often too does he intercept the tern while it carries home, for a long way, a small provision in its bill for its family, but this merciless invader seizes all, and renders the longest journeys often useless. These birds come about the same time, and withdraw together, but whether their place of retirement is the same I am unacquainted.

This species is furnished with long wings to perform long and quick flights, with a forked tail to guide its way, and to assist it in these sudden motions it is obliged to make in searching for and seizing its prey. This use of the tail in directing the motions of a bird is pointed out by Mr Ray, in the following words :- 6 In those that have forked tails, autopsy " convinceth us that it hath that use. For it is manifest to "s sight, that the forked tail kite, by turning her train side" ways, elevating one horn and depressing the other, turns " her whole body; and doubtless the tail hath the same use 
" in swallows, who make the most sudden turn in the air of " any birds, and all of them have forked tails."

Where the sea-swallow retires to in winter I cannot say, but it leaves us entirely when this season comes on ; probably retires to the warmer climates.

\section{GENUS XXXI.-PETRELS.}

Gen. Char.-Bill straight, but hooked at the end; nostrils cylindric, tubular; tongue; legs naked above the knees: back toe, none; instead of it a sharp spur pointing downwards.

\section{Species 1.-The Shear-Water.}

Manks Puffin, Wil. Orn. 333. Raii Syn. Av. 134. Shear-Water, Idem, 133. Procellaria Puffinus, Lin. Sys. 21s. Brit. Zool. 433. Manks Petrel, Brit. Zool. fol. 146. Orc. Lyre. Avis Orcadensis Lyra dicta anate minor, et pluviali major, pinguissima, saporis pisculenti. Sib. Scot. 22.

TH Is bird is the chief acquisition our rock-men get for all the danger in climbing the most dreadful precipices ; for this, one sitting on the brink of the rock, with a coil of rope made of hair on his arm, will let his neighbour many fathoms over the steepest rocks, such as would make others shudder only to look at, and yet these people think no more of it than an airing; and though few years pass without some or other of 
them perishing, yet that never deters the survivors, - - such an influence has the love even of a little gain on the human mind, that not the most imminent dangers can deter them from pursuing it at all events, even though death stares them in the face every moment they are on these expeditions. The smallest accident may ruin them,- the untwisting of the rope, -the slipping of a noose, - the rubbing of it on the rugged rocks, - all may and sometimes are fatal to the climbers; yet so venturesome are they, that they often let one another down small heights with straw ropes. Well might the poet call this a "horrid trade;" it is really dreadful to see people. let over a rock several hundred fathoms height, with the deep below them, supported only by the single arm of their comrades, who have nothing to rest themselves against, but must depend on their strength for both their preservation: sometimes, indeed, both slip together.

The lyre comes to these rocks in February or March, and some time after their arrival build in holes of the little earth that is to be found in the interstices of the rocks; lays a single white egg, something like a hen's, but blunt at each end. In August the young are fit for taking, and are very much sought after as delicacies by those who love good cheer. They are, indeed, very fat, but are nauseously rank and fishy tasted; however, they sell pretty high, and are lucrative to the captors. The country people salt them down for winter provision, and boil them with cabbage; what sort of a dish this makes I cannot say, but suppose not extraordinary. They 
likewise take the old ones in March, but these are poor, and not near so good as the young.

An old lyre weighs seventeen ounces; in length eighteen inches; breadth twenty-six ; the bill is about an inch and a half long; the upper mandible black, the lower lead-coloured; the nostrils are placed very near one another in a bald skin of the upper part of the bill, they are small and round ; the body is long and cylindrical; the back and whole upper side black ; the throat; breast, and belly white; the feet are placed very far back; the leg bones thin, the colour various, in some greenish and black, in others white before and black behind.

'There are various accounts of the manner of feeding of this bird ; however, the make of its bill, I should think, pronounces it a fisher, and in the stomach of one I dissected I found a piece of a fish, surrounded with a greenish liquor, but so much decayed that I could not make out what kind it was. Our country people say it scums the water, and lives on the oil it finds there ; but the form of its bill denies that. The last notion is from its spouting a quantity of oil from its throat; but this is not peculiar to it, but to the whole genus, and is its food reduced to this in its stomach. 


\section{Species 2.-The Stormfinch.}

Sib. Hist. Fife, 48. Procellaria pelagica, Lin. Sys. 212. Wil. Orn. 395. Brit. Zool. 434. Brit. Zool. Illus. pl. 82. fig. 1. Orc. Alamouti.

The Stormfinch is very frequent in all the seas round Orkney. I met with it in Stronsa Frith and elsewhere; but it never approaches the shore except in the breeding-season. This is performed in the rocks and uninhabited isles; and as soon as this is over, it betakes itself to sea, and we never see it till that time twelvemonth.

Our fishermen often fall in with the stormfinch at sea, but they do not like them, for they are sure of a gust of wind immediately to follow as often as they approach the land.

I never could observe it but on the wing, or skipping from wave to wave, dipping its bill now and then in the water, as if in search of insects, nor does it seem to be a diver. 


\section{GENUS XXXII.-THE MERGANSER, OR DIVING- GOOSE.}

Gen. Char.-Bill slender, a little depressed, furnished with a crooked nail at the end, edges very sharply serrated; nostrils, near the middle of the mandible, small and subovated; tongue slender; feet, the exterior toe longer than the middle.

\section{Species 1.-The Goosander.}

Goosander, Wil. Orn. 335. Dundiver or Sparling-Fowl, Ibid. Raii Syn. Ao. 134. Mergus Merganser, Lin. Sys. 208. Brit. Zool. 436. Brit. Zool. Illus. tab. 83. Orc. Harle.

Witu us the Goosander continues the whole year, and may be seen every day in numbers on the lakes and in the sea; builds on the small holms of the loch of Stenness, along with other birds ; in harvest and winter fly in large flocks, in summer in pairs ; the male and female are then strict companions, but, like many other birds, when breeding-time is over, part company, and lose acquaintance.

The description of this bird is exactly the same as in the British Zoology, only I take the second species there described to be the female of the above, as those I have killed are of the same weight, have the very same marks ; and indeed I cannot think I am mistaken, as I have killed both birds together. 
I once killed a bird of this kind in Orkney which weighed two pounds, except two ounces; it was a male, the colours were the same, the shape of the bill and legs the same as in the larger goosander, only the whole head, neck, and breast were black. It could not be a young bird, as it was in March I shot it, when these birds have not bred.-Qucere, What bird might it have been the male of?

The goosanders are excellent swimmers and divers ; continue very long under water; are excellently furnished for seizing and holding any small fish they can catch in the water; the bill is not only formed with a nail or hook, but the edges are toothed the whole way, so that there is no escape for the prey.

The colours of the bill and head of the male and female are much different. In the former it is of a fine red, especially in the spring, the head and crest black, with a white collar about the neck. In the female, the bill is dusky above and red below; the head and neck brown inclining to red; the ring not so well defined; the whole body is much browner; the marks on the wings are the same, only fainter in the female. 


\section{GENUS XXXIII.-DUCKS.}

Gen. Char.-Bill strong, broad, flat, or depressed, and commonly furnished at the end with a nail, edges marked with sharp lamellæ; nostrils small, oval ; tongue broad, edged near the base, fringed; feet, middle toe longest.

\section{Species 1.-The Wild Swan.}

Wild Swan, Elk, or Hooper, Wil. Orn. 356.' Raii Syn. Av. 136. Anas Cygnus ferus, 194. Brit. $z_{0 o l .440 .}$ Sib. Scot. 21.

The Wild Swan is found at all seasons in Orkney; a few pairs build in the holms of the loch of Stenness. Here, in that fine piece of water,-

The stately sailing swan

Gives out his snowy plumage to the gale;

And arching proud his neck, with oary feet,

Bears forwards fierce.

- But, alas for the taste of our Orcadians! he cannot

\section{Guard his osier isle,}

Protective of his young.

But the few that build here never increase; are always robbed by the country people. These, however, are nothing to 
[Birds.

the flocks that visit us in October from the northern climates, their summer retreats. Part of these continue with us all winter, and the rest go to Caithness and the other northern shires of Scotland ; in April they go off again to the northward, except, as I said before, the few which remain here for the summer.

When the swans go soon away, our country people expect a forward season; but when they fly south in the spring, fear the worst.

Like the wild geeese, these birds fly in the fashion of a wedge, making a fine melodious clang, which has perhaps furnished one occasion to give a musical voice to this bird.

\section{Species 2.-The Goose.}

Tame Goose, Common Wild Goose, Wil. Orn.358, sp. 1, 2. Raii Syn. Av. 136, sp. 3, 4. Anas Anser, A. ferus $\beta$, domesticus, Lin. Sys. 197. Brit. Zool. 447. Brit. Zool. Illus. tab. 84 .

The Wild Goose is very seldom seen here, pays us no regular visits; I have heard, however, an instance or two of a male joining itself to a flock of tame geese, and continuing with them the whole season.

Tame geese in Orkney are bred in vast quantities; not so much as the smallest farmer but has his flock of these ; they are part of the rents of the farms, and strictly exacted; when 
sold to the merchant fetch aboul eightpence or tenpence, seldom above the last price.

When cured many of them are sent to the Leith market, where they sell tolerably well; but the feathers of geese make a very considerable article in our Orkney exports: these are sold at about tenpence or a shilling per pound, and the demand is still great for them. We have not here got into the method of plucking our geese till they are killed, which is in November, when there is a general slaughter of the birds of the same year, and none kept but a few for Christmas, and the brood geese for next season.

\section{Species 3.-The Bernacle.}

Bernacle or Clakis, Wil. Orn. Ruii Syn. Av. 137. Sib. Scot. 21. Brit. zool.451. Anas Erythropus, (mas), Lin. Sys. 197.

TuE Bernacle sometimes appears here in flocks in spring, I suppose in their way to the north country; for any thing I can learn, do not build here, and but touch here by chance. I met with a skin of one of those which was killed out of a flock which had hovered here a while in their passage. 'The bill was short and black, with oblong nostrils; the head small; the neck long and slender; the face and cheeks white; the rest of the head, the throat, and breast, as also the back, a good black; the root of the tail white; the tail black; the wings 
were a sort of deep ash-colour, barred with white and black; the feet were black.

This is the bird which the ancients imagined to be bred from a shell-fish, the absurdity of which is some time ago found out, - that the fish continues as it was formed, and the bird no doubt is produced according to the ordinary methods of generation. The shell was the Lepas anatifera, Lin. Sys. 668. These shells are sometimes drove in here, adhering to pieces of wood, or tangles, in thousands.

\section{Species 4.-The Brent Goose.}

Wil. Orn. 360. Raii Syn. 137. Anas Bernicla, Lin. Sys. 198. Brit. Zool. 452. Orc. Horra Goose?

I HAVE seen a flock of half a dozen of these in Hoy Sound in winter, which is the only season they appear in Orkney.

I have often been informed, but never could obtain a specimen, of a bird of the goose-kind which appears in Deer Sound in the fall, and goes off in spring, and, by the general description, I imagine to be this species.

The name in Deerness is Horra Goose, and is described as a large gray bird, with a black head and hoarse cry. 
of tebbe tisum be Species 5.-The Eider Duck.

Wormius's Eider or Soft-feathered Duck, the Cuthbert Duck, Wil. Orn. 369. Ruii Syn. Av. 141. Eider Anas, Sib. Scot. 21. The Colk, Mart. West. Isles, 25. Colca, Buch. Hist. Scot. lib. 1. Anas mollissima, Lin. Sys. 198. Brit.Zool. 454. Orc.* Duntergoose. Pen.Tour. 37.tab.1.

These birds in winter frequent our sounds and bays in large flocks, both of males and females, but for the most part go off in the spring. A few pairs build in a holm belonging to Trail of Holland, in the north isles, constructing their nests of sea-tang and the down of their own breasts.

This is a very beautiful bird, especially the male, the bill of which is black, as is the forehead, and a broad black bar from the bill to the eyes, which passes to the hind part of the head; the crown of the head, the cheeks, the neck, back, scapulars, and coverts of the wings are white; this is finely variegated by the lower part of the breast, the belly, the tail, and quill feathers, which are a full black. The female has none of these colours; she is of a uniform brown, barred with black; the quills black; the belly a deep brown; the tail dusky.

These ducks in spring swim in flocks, and nothing can be more pleasant in a fine day than to see two or three dozen of them sailing by ; the lively black and white of the males, intermixed with the darker colours of the females, contributes

* Vide Sib. 21. 
much to diversify the scene; they are very thick of feathers, which makes them sit high on the water, and much adds to their appearance.

We have not so many of them with us in the breeding season as to make any thing of the down.

\section{Species 6.-The Tufted Duck.}

Wil. Orn. 365. Raii Syn. Av. 142. Anas fuligula, Lin. Sys. 207. Brit. zool. 428.

THIs duck is often forced against its will to pay us a visit; does not build here that I can learn; only comes in stormy weather, and goes off again when it is calm.

The head is a shining black, with a hanging crest of the same colour ; the back and whole body, except the belly and a spot on each wing, is black.

The female has no observable crest, and is much browner than the male. While here they are close companions, never part, but come and go together.

Several other birds of this kind may perhaps pay us transient visits, but they are often so short, irregular, and to such distant parts of the country, that there is no getting any account of them ; and oft-times many curious birds are caught by such as have no curiosity, further than to try what taste they have, and of consequence they are altogether lost to the Faunist.

The others of the duck-kind found about these islands are as follows. 


\section{Species 7.-The Shieldrake.}

Shieldrake or Burrough Duck, Wil. Orn. 363. Raii Syn. Av. 140. Auas Tadorna, Lin. Sys. 195. Brit. Zool. 461. Orc. Slygoose.

TuIs is the most beautiful of the genus which is found in these isles. The bill of a male is a fine red, very much crooked and turned up, the base has a large soft knob, which swells much in spring, and is then of a brighter red than at other seasons of the year; the head is a fine deep green, below which is a white collar; the breast and shoulders are surrounded by a band of bay; the back is white, with a black stripe on each side; the covert feathers of the wings white; the first quill feathers are black, the next green, after which follow three of a deep bay; the tail white, tipped with black; the belly white, divided by a black stripe, which begins in the band of bay on the breast, and running between the thighs, ends about the vent ; the legs a pale flesh colour.

The slygoose comes to us in the spring, and builds in holes of the earth, commonly in rabbit holes, and retires when breeding-time is over. They may easily be tamed; I have seen a flock of them up at a gentleman's house, where they ran about the doors with other fowls. They seemed to be weakly and delicate in their tame state, could make no shift for themselves, but must be fed by the hand. 'The winter seems not to be easily borne by these birds, and they retire no doubt to warmer climates. 


\section{Species 8.-The Mallard.}

Common Wild Duck and Mallard, Common Tame Duck, Wil. Orn. 371, 380. Raii Syn. Av. 145, 150. Anas Boschas. A. domestica. Lin. Sys. 205. Brit. Zool. 462. Brit. Zool. Illus.tab.24. Orc. Stock Duck.

WrLD DUCKs build in great numbers through the country, in the marshes, meadows, and holms ; but this is nothing to the flocks of them that migrate hither in winter, and perfectly cover our lochs and bays. These make this their retreat till the return of spring drives them off from us. We have no way of catching these but by the gun and water-spaniel, and they are generally so wild there is no such thing as coming near them. The great resort of ducks is to the loch of Stenness, and others through the mainland and isles ; and, when these are frozen, the sea ; in these places they may be seen in winter in surprising numbers, and upon the report of a gun rise like clouds.

Sometimes the wild duck's eggs are hatched under a hen, and thus tamed, but for a long time retain the marks of their wild ancestors, falling off from them by : degrees, by mixing with those which are still farther removed from their wild state. Ducks sell here for sixpence a-piece. 


\section{Species 9.-The Pintail Duck.}

Sea Pheasant or Cracker, Wil. Orn. 376. Raii Syn. Av. 147. Anas acuta, Lin. Sys. 202. Brit. Zool. 368. Ore. Caloo, or Coal and Candle Light (from its cry.)

THIs Duck is to be found very frequently in the sound of Hoy, though only in winter; it withdraws from us in spring. I never had an opportunity to examine this species very near, therefore must give the description from the British Zoology. 66 The form is slender; the neck long and small ; weight "6 twenty-four ounces; length twenty-eight inches; breadth " one yard two inches; the bill black in the middle, blue on 66 the sides; the head ferrugineous, tinged behind the ears 66 with purple; from beneath the ears commences a white "6 line, which runs some space down the neck; this line is 65 bounded by black; the hind part of the neck, the back 66 and sides are elegantly marked with white and dusky waved " lines; the fore part of the neck and belly white; the sca" pulars striped with black and white; the coverts of the " wings ash-coloured, the lowest tipped with dull orange; " the middle quill-feathers barred on their outmost webs with " green, black, and white; the exterior feathers of the tail " are ash-coloured, the two middle black, and three inches " longer than the rest ; the feet of a lead colour."

I met with a couple of these, but they were plucked and ready for the spit before I saw them, so that I could not exa- 
[Birds.

mine the feathers, but those who ate them said they tasted wild. They fly in pretty large flocks, keeping much in the sea.

\section{Species 10.-The Sroallow-tailed Shieldrake.}

Wil. Orm. 364. Raii Syn. Av. 145. Anas glacialis, Lin. Sys. 203. Brit. zool.368. IV.pl. 86.

ThIs species is the constant inhabitant of our fresh water lakes through the winter. It comes in October in large flocks, and continues till April, when it disappears for the summer, retiring to the north.

This species does not confine itself to the fresh waters. About sunset they may be seen in vast flocks going from or returning to the sea, where they frequently pass the night with a great noise, which may be heard at a vast distance, especially in a still frosty night, when it may be heard some miles.

These are not so shy as the former species ; are pretty frequently shot, but not much admired for eating. 
Species 11.-The Wigeon.

Wigeon or Whewer, Wil. Orn.375. Raii Syn. Av. 146. Anas Penelope, Lin. Sys. 202, Brit. Zool. 472.

Trus species is found pretty frequent, but whether it continues with us the whole year or not, I am uncertain. The colours of one I saw lately stuffed were as follow: The bill black at the point, the rest of it lead-coloured; the crown of the head yellowish, the rest of it red, except a fine changeable spot which runs from the eyes; the throat black; the breast reddish; the back and about the wings finely striped and chequered, with narrow waves of black and white; the belly white; the wings, with dusky quills, a green speculum, and pretty large white spots on them; the covert feathers edged with white; the legs blackish.

This bird was shot in the loch of Skail, on the mainland, where vast numbers and variety of the duck-kind come in winter and stay till spring. They live on the eels, which are the only fish the loch affords, and the larvæ of the ephemera, which is to be found in it in vast quantities, and affords them an excellent repast; as also no doubt on the pond weeds which abound in this loch. 


\section{Species 12.-The Garganey.}

Wil. Orn. 377. Querquedula prima Aldrovan. Raii Syn. Av. 148. Anas Querquedula, Lin. Sys. 203. Brit. Zool.474. Brit. Zool. Illus. 87. fig. 1.

Turs species is often found in our lochs in winter, as likewise in stormy weather in the sea : I have seen it in stormy frosty times on the bay of Birsa. Whether it stays with us through the year am uncertain, rather think not.

It is seen in the loch of Stenness, and the road called Kerston Bay, in vast numbers, but very shy, insomuch that I never could procure a single specimen.

\section{Species 13.-The Teal.}

Wil. Om. 37\%. Raii Syn. Av. 14\%. Anas Crecca, Lin. Sys. 204. Brit. zool. 475.

A Beautiful male Teal which I received from the loch of Stenness weighed thirteen ounces ten drachms; the length fifteen inches; the breadth twenty-seven; the bill was black, with a small nail ; the head bay, with a band of green running to the back of the head, parted from the bay on the lower side by a very narrow white line; the throat and upper part of the neck bay; the back finely chequered with waving lines of black and white; the breast most curiously spot- 
ted with black, each feather having a spot; the belly a dull white; the tail pointed, white underneath; the vent black; the wings had the quills dusky, with green specula; the legs and feet dusky.

The teal continues with us the whole year; builds in the marshes and wet places, often in rush bushes.

Besides this, I have seen another bird of the teal-kind here called Atteal *. It is found in our lochs in great numbers in winter ; is very small, brown or dusky above, and a yellowish belly; but I have not been able to procure specimens of it, so as to distinguish it properly.

\section{Species 4.-The Golden-Eye.}

Wil. Orn. 368. Raii Syn. Av. 143. Anas clangula, Lin. Sys. 201. Brit.Zool. 460.

SEEN only with us in winter, when we observe them in flocks of a dozen ; easily distinguished from all the duck-kind by the white spot at each corner of the bill; the female less than the male; oftener found lurking in the sedges of fresh waters than in the sea, which she frequents mostly in frosts; the male found mostly in the sea, where he is continually diving. The female is easily known from the male by the colour of

* In a storm (winter 1773-4), I met with a bird of the teal-kind, nothing differing in colour from the above description, but only weighing nine ounces and a half, but whether this is the male atteal am uncertain. 
$[$ Birds.

the head, which is brown ; the neck much more faintly marked with the white ring; the coverts dusky.

\section{GENUS XXXIV.-THE PELECAN.}

Gen. Char.-Bill long and straight, the end either hooked or sloping; nostrils either totally wanting or small, and placed in a furrow that runs along the sides of the bill ; faced naked; gullet naked, and capable of great distension; toes, all four webbed.

\section{Species 1.-The Cormorant or Corvorant.}

The Cormorant, Wil. Orn. 329. Raii Syn. Av. 122. Pelecanus Carbo, Lin. Sys. 216. Brit. Zool. 476. Orc. Great Scarf.

THIs bird is very frequent both in salt and fresh water; continues with us the whole year, living on fish, of which it destroys vast numbers.

The whole bird is black, except the throat and a tuft of feathers on the thighs ; the bill is large, dusky, and hooked; the throat capable of opening very wide, and it can swallow a very large fish ; the tail consists of fourteen feathers, which is a character distinguishing it from the next; the belly in some is a dusky white, in others darker.

The corvorant seems to have but little other concern than how to eat enough ; it is indeed surprising what quantities of fish it will gorge itself with, and, when it has filled itself to 
the throat, retires to some point where it sits till hunger compels it to the water again. A female corvorant weighs seven pounds and a half.

\section{Species 2.-The Shag.}

The Shag, called in the north of England the Crane, Wil. Orn. 330. Corvus aquaticus minor, Graculus palmipes dictus, Raii Syn. Av. 123. Pelecanus graculus, Lin. Sys. 217. Brit. Zool.478. Brit. Zool.1llus.tab.25. Orc. Scarf.

THE general appearance of this bird is the same with the former, only it is much less in every proportion, and this has but twelve feathers in the tail. The whole bird is black*; the back has a greenish cast ; the belly dusky; in females and young birds the whole body is of a dusky brownish black ; the legs are black.

The manners, the haunts, and every part of the history of these two birds is the same, but the shags are much more numerous: I have observed sometimes five hundred in a flock, especially where they had fallen in among a school or shoal of small fish.

They build like the former in the rocks, making a large nest of tang, and lining with softer materials; lay from four

* There is a variety in Orkney pretty frequent, with a white belly; in other particulars, as far as I can observe, not different from the former. A grown scarf weighs four pounds. 
[Birds.

to six eggs of a white colour ; fly a great way for fish, especially while they are scarcest, that is, while the young fish are so small as to be unobserved by them.

Our Hoy men and other rock-men tell us they sit in very large flocks on the rocks, and one keeps watch while the rest are asleep; if they can catch the watcher they are sure of the whole, but if he gives warning they all throw themselves over the rock into the sea. 'The rock-men go in the night-time to the places where they frequent, and catch many of them as above.

\section{Species 3.-The Gannet.}

Soland Goose, Wil. Orm. 328. Raii. Syn. Av. 122. Sib. Scot. 20. tal. 9. Mart. Desc. West. Isles, 281. Pelecanus Bassanus, Lin. Sys. 217. Brit. Zool. 479. Pen. Tour. 165, tab.8. Orc. Solan.

The Solan Goose breeds in none of the Orkney Isles, as far as I can learn, but is very frequent in our bays, where great numbers of them may be seen fishing, after their manner, together. I have observed they dart briskest in windy weather; perhaps the motion of the water disturbing the fish, makes them appear better to this quick-eyed observer; however this is, the bird flies slowly along till it sees a fish, when it immediately throws itself on its back, and darts at the fish. Whether this last particular of its throwing itself on its back has been before observed I know not, but have myself observed it many and oft times. The nearest land to Orkney where 
the solan goose breeds is a rock called the Stack of Soliskerry, where many hundreds breed every year, as the seals do on the Skerry. Sometime ago a ship went from this place thither, and returned with a great quantity of young solans, the feathers of which were good, as they were not near so oily as those of the older sea-fowl ; the birds were eaten, but were very wild and fishy tasted, with a strong smell.

In the air, or at a distance, the solan goose has much the appearance of very large gull, but may, to an attentive observer, be distinguished by the following tokens: The neck is much longer; the body more cylindrical ; the wings placed farther back than in the gull-kind ; and the method of flying is much more equal than in that genus ; which is all that needs to be said of this bird, after the excellent description given of it in the British Zoology.

\section{ADDENDA.}

\section{The Coot.}

Wil. Orn. 319. Raii Syn.116. Fulica atra, Lin. Sys. 257. Brit. Zool.392. Orc. Snyth.

ThE Coot is found here at all seasons, and in several places, 
particularly at Burwick in South Ronaldsha, and Aikerness in Evie; builds in grassy lochs, amongst which it conceals itself; lays a number of eggs, sometimes seven. It can fly, though something awkwardly; swims with its head grovelling in the water.

\section{The Turnstone.}

Turnstone or Sea Dotterel, Wil. Orn. 311. Morinellus marinus, Raii Syn. Av. 112. Tringa Morinellus, Lin. Sys. 249. Brit. Zool. 370.

THE bird described in the British Zoology underthis name, is found in small flocks round the shores of Orkney, though only in winter. Migrates in spring, probably to the northward, as most others do which leave us in the summer.

\section{The Peregrine Falcon.}

Falco peregrinus niger, Ald. I. 239. Brit. Zool. 136, tab. 4. pl. 52. (tabula optima.) Orc. Falcon.

THis species found in all our head-lands and other inaccessible rocks. It is the falcon or more noble species of hawk which was formerly so much coveted, and brought from Orkney. In the Burgh of Birsa I observe the dark-coloured kind of this species, so beautifully engraved in the additional vo- 
lume of the British Zoology. It is likewise found in Marwick-head, Hoy, Walls, Copinsha, and elsewhere in Orkney; likewise in the Fair Isle and Foula ; as also in Lamhoga of Fetlor, Fitful, and Sumburgh-Heads of Shetland.

Never more than one pair of this species inhabit the same rock; and when the young are fit, they are driven out to seek new habitations for themselves. The falcon's nest, like the eagle's, is always in the very same spot, and continues so past memory of man. 



\section{CLASS III.-REPTILES.}

\section{GENUS I.-THE FROG.}

Gen. Char.-Body naked; four legs, the feet divided into five toes; no tail.

\section{Species 1.-The Common Frog.}

Rana aquatica, Raii Syn. Quad.447. Lin. Sys. 377. Brit. Zool. III. 3.

Found in vast numbers in a small loch near Stromness, where they deposit their spawn in the spring, which soon becomes a sort of fish-like animalculi, making its way through the waters by the wriggling motion of a membranous tail. The shape of it in its tadpole state is a flatted hemisphere, or rather ellipse, in one end of which is placed the mouth and eyes, and the other contains the tail. When the tadpoles have been some days in the water, the hind legs begin to appear on each side of the tail, which then begins to grow shorter ; these still appear plainer, till the thighs are excluded, and the 
body shrinks from its roundish figure, and the loins are formed. The fore-feet are then thrust out by degrees, and the creature having no more need of its tail it disappears, and the new animal leaves its watery habitation for the land, to which, however, it is not so closely confined but it can visit its first abode. The tail of a tadpole makes an excellent object in the solar microscope, and serves much better for illustrating the long-disputed proposition concerning the circulation of the blood, than those cruel operations often perfe.med upon the larger animals, with neither half the pleasure nor satisfaction, for here it is rendered as visible, and conveyed to us in as direct a manner as our senses can.

The frog is so common an animal as to need no description, though not here very common in its frog state, owing, I suppose, to the vast numbers of tame geese and ducks reared here, which perhaps devour them.

\section{Species 2.-The Toad.}

Bufo sive Rubetra, Raii Syn. Quad. 252. Rana Bufo, Lin. Sys. 354. Brit. Zool. III. 7. Sib. Scot. 13.

THIs species is often found in the evenings in gardens, crawling in search of food no doubt; never leaps as the frog; its appearance ugly, and in some measure terrifying. Whereever it is to be found, the same prepossession against it, all give it up to destruction, and often practise the most wanton cruel- 
ty over this poor creature, who is perhaps no further blameable than in having but an ordinary outside ;-hard fate! that its features should be its ruin ; but in this respect it is not singular. It seems odd that mankind should take pleasure alike in destroying the most horrid and the most beautiful pieces of the creation.

Mr Pennant, in his British Zoology, has been at great pains to vindicate this creature from the character it has long laboured under, of being poisonous, and with arguments and proofs has set this matter almost out of dispute, and, indeed, as he well observes, its unhappy deformity seenis to be the only reason for suspecting harm from it. Of all the lugubrous stories I have heard with regard to the toad, I never could get one fixed to time and place, or even persons, all of them hearsays; and however unjust it is to be condemned upon hearsay, this seems to have been the fate of this animal. It is certain that, added to its deformity, nature has thrown it into a class of animals, many of whom are confessedly dangerous; but these are all furnished with proper weapons of offence, and the manner and reason of their doing harm is easily traced; this, however, is not the case with the toad. I have not heard from any acquainted with dissections, that he is furnished with the fangs of the viper, or the pretended stings of other serpents ; it furnishes a meal for many other animals, who would be as ready to be affected by this supposed poison as man. In a word, we may consider this reptile as harmless, and affirm there is no venomous creature above an insect in the Orkneys. 
Whether there are any Lizards in the Orkneys I cannot say, rather think not; and of the Serpent-kind happily not one.

To follow the method Linnæus has laid down in his System of Nature, the Cartilaginous Fishes ought to come in here, but these scarce can be called amphibious; notwithstanding of their capacity of living in the water, they cannot subsist for any time at land; nay, there are of these which are more properly termed Fishes, can live much longer at land than any of these can : for example, eels, which have been observed to pass from pond to pond over the moist meadows, like as many serpents. Frogs are really amphibious, and can live both on land and water; Serpents are in some measure so, and can live some time in the water,- - but these perish soon aftertheir being drawn ashore. To place then all the fishes together, we shall follow the method laid down in the English authors, rather than the Swedish, in this particular. 


\section{CLASS IV.-FISHES.}

DIVISION I.-CETACEOUS.

\section{GENUS I.-CETACEOUS FISH.}

Gen. Char.-Cetaceous fish, without teeth, with horny laminæ in their mouths,

\section{Species 1.-The Common Whale.}

Balæna vulgaris edentula, dorso non pinnato, Raii Syn. Pisc. 6. Balæna, Rondelet. Wil. Icth. 351. Balæna Mysticetus, Lin. Sys. 105. Balæna major, laminas corneas in superiore maxilla habens, fistula donata, bipinnis, Sib. Phal. Brit. Zoot. 35.

Nor undelighted by the boundless Spring Are the broad monsters of the foaming deep From the deep ooze and gelid cavern rous'd, They flounce and tumble with unwieldy joy.

Thomson.

ThIs vast animal has now, in a great measure, taken its 
leave of our seas, forced to the northward, I suppose, by the resort of shipping, which is now much greater than formerly. There have been several instances of late years of their driving ashore on our coast, particularly one some years ago, which was thrown upon the island of Walls, measuring about forty feet long, but so much spent, by driving long at sea, that it gave no oil ; and how they managed the whalebone, or how it turned out, I know not. Other instances there have been where the capture has been more valuable, though perhaps not near so much so as it would have been, had the fish been got in time; for I imagine those which come here are wounded ones from the Greenland seas, which drive all the way hither, are half rotten, and their oil gone, before they arrive. In Scotland, the admiral of the district claims all fish of this kind above a certain measure.

\section{Species 2.-The Round-lipped Whale.}

Balæna tripinnis maxillam inferiorem rotundam, et superiore multo latiorem habens, Sib. Phal. 78. Idem. Raii Syn. Pisc. 16. Lin. Sys. 106.

These are seen in our seas much more frequently than the others, especially about July and August, at which time the sounds and sea are full of herring and mackerel, upon which they feed. I saw a very ordinary representation of a fish, which, about twenty years ago, had drove ashore in Hoy, and which seemed one of this kind by the situation and number 
of the fins, and the account I got of it did not contradict the opinion. The mouth was large, or, as they expressed it, so wide that a man might have entered it on horseback; the lips very thick; a fin on the back; and whalebone in its mouth. The dimensions were forgot, but it was a very large fish. I saw one since in Flotta, fifty feet long.

The length of this species is sometimes very great: One taken at Abercorn Castle was seventy-eight feet long, the circumference thirty-five; the tongue fifteen feet and a half long; mouth furnished with whalebone, three feet long; the forehead furnished with tiwo spout-holes of a pyramidal form.

The eyes were thirteen feet from the end of the nose; the pectoral fins ten feet long; the back fin about three feet high, placed near the tail, which was eighteen feet broad; belly full of folds.

\section{Species 3.-The Beaked Whale.}

Bottle-head or Flounders-head, Anglis. Brit. Zool. 43. Orc. Bottle-nose.

BotT LE-NOSE WHALES sometimes run ashore in great numbers with us, two hundred at a time, of different sizes, from eighteen to ten feet. I never had the good fortune to see these in such numbers, or on shore, as none of them have been got in Orkney these seven years. I have often observed them in small numbers off the Black-Craig of Stromness, and within the sounds single fish. One was got some years ago near 
Breakness, and another in Breabuster in Hoy; the greatest numbers were wont to set into the harbour of Stromness and elsewhere, and were killed or run ashore by the country people. A good deal of oil was made of the fat, but I did not hear of any whalebone, and suppose, from the size of the fish, it would be of little value.

I should imagine these whales to be migratory, as they appear in some seasons in vast numbers in these seas, and great numbers are caught; then, for many years, withdraw themselves altogether, so that scarce one is observed. Where they go $\mathrm{I}$ am unacquainted, but incline to think they make us no regular visits, like the porpoise, and others of these fishes.

\section{GENUS II.-CACHALOT, OR SPERMACETI WHALES.}

Gen. Char.-Cetaceous fish, with teeth in the lower jaw only.

\section{Species 1.-The Great-headed Cachalot.}

Balæna major in inferiore tantum maxilla dentata, dentibus arcuatis falciformibus, pinnam sive spinam in dorso habens, Sib. Phal. 33. Raii Syn. Pisc. 15. Physeter microps, Lin.Syst. 107. Brit. Zool. 46. Orc. Spermaceti Whale.

THIs kind of Whale is often drove ashore about the Ork- 
neys, nay, and sometimes caught. One about fifty feet long was caught in Hoy Sound some years ago, from which was extracted a vast quantity of spermiaceti, as also another which drove ashore in Hoy. However, our people do not seem to understand the method of curing the spermaceti properly, as that got from the former was very much complained of by the merchant who bought it. The spermaceti is entirely contained in the vast head of the animal, and is got at by opening the skull and taking it out with buckets. It likewise afforded a vast quantity of oil. All the kind seem to be very mischievous.

\section{Species 2.-The Round-headed Cachalot.}

Balæna minor in inferiore maxilla tantum dentata sine spina aut pinna in dorso, Sib. Phal. 24. Raii Syn. Pisc. 15. Physeter Catodon, Lin. Sys. $10 \%$. Brit. Zool. 47.

Sir Robert Sibbald tells us of a hundred and two of different sizes being thrown ashore in the harbour of Kerston in Orkney (now called the harbour of Stromness). "The " largest of these," says he, "was twenty and four feet long, " some eighteen, others fifteen, and the smallest twelve." His description is as follows:-

"The head was round; the opening of the mouth small; " toothed only in the lower jaw, and having in the upper " a number of holes, equalling, and for receiving the teeth of 
" the lower jaw; the teeth were flat on the top, and stood " out only an half an inch without the gums." Sir Robert says these had no spout-hole, but Mr Pennant, with more appearance of truth, thinks what Sir Robert took for nostrils, by being placed at the extremity of the nose, was that part which is peculiar to the whale-kind, and wanting in none, though differently placed in different subjects.

This kind had two pectoral fins, and a rough space on the back, but no fin or spine. Whether spermaceti was found in this, Sir Robert was uncertain, but it is probable there was, as all the known whales of this genus which frequent the British coasts, are found to yield more or less of this.

\section{Species 3.-The High-finned Cachalot.}

Balæna macrocephala tripinnis, qua in mandibula inferiore dentes habet minus inflexos et in planum desinentes, Sib. Phal. 43. Raii Syn. Pisc. 16. Brit. Zool. 47. Physeter Tursio, Lin. Sys. 107.

ONE of this species is recorded by Sir Robert Sibbald, which was thrown ashore on the Orkneys in 1687. This was a very large female. The spout-hole was placed in the front, the head, according to his description, was eight or nine feet high; toothed only in the lower jaw ; the teeth were slightly bent, much compressed on the sides, the point rather blunt than flat; the bottom thin, having a very narrow but long orifice, or slit, hollowed to the depth of five inches and a quarter, in 
a tooth the length of which was seven inches three quarters ; the tooth was immersed in the jaw as far as that hollow.

It had two pectoral fins, and a third situated on its back, which Sir Robert compares to the mizen-mast of a ship. The head was full of spermaceti of the best sort.

See Plate III. Vol. 3. fig. 1. British Zoology, for a figure of the teeth of this species.

Sir Robert Sibbald speaks of another vast fish of this kind, but seems not to be certain what species it was, because of the lame description he had of it.

\section{GENUS III.-CETACEOUS FISH, WITH TEETH IN BOTH JAWS.}

. Species 1.-The Porpesse.

Porpesse, Wil. Icth. 31. Raii Syn. Pisc. 13. Delphinus Phocæena, Lin. Sys. 108.

IN the summer season, in May especially, June, July, and August, porpesses swarm in our seas; often seen in flocks of hundreds, making the whole sea foam again, while they pursue the lesser fishes, or the females are in season, which I think happens in May, as they are then most frolicksome, and make the greatest stir, keeping together in greater numbers in that month than other times of the year. The porpesse comes regularly into our sea when the colder months 
are gone, and retires when they return, impatient, I suppose, of the cold of our winters ; but however this is, not a porpesse is to be seen in these seas in the more rigorous season, though in summer we can scarce cross a sound without seeing two or three of them blowing round the boat.

Porpesses sometimes set into the small bays in vast numbers, and are inclosed and drove ashore by the people, who are always upon the watch, and often make a good deal by the capture. They are fat, and yield, for their bulk, a good deal of oil. The people here tell us (with what truth I know not), that porpesses have so much of the nature of swine, that force one ashore, the rest will every one follow, though there were a thousand in the flock. If this is the case, this is not the only thing in which these creatures agree in their natures, as is well known to those conversant in the study of nature : their method of life is in some respects the same*; the conformation of their parts something similar; and a "porpesse " has the warm blood and entrails of a hog $\uparrow . "$

* Vide Brit. Zool. tit. Porpesse.

+ Mr Locke, quoted by Baker, Mic. p. 309. 


\section{Species 2.-The Grampus.}

Balæena minor utraque maxilla dentata, Sib. Phal. 17. Wil. Icth. 40. Raii Syn. Pisc. 15. Delphinus Orca, Lin. Sys. 108. Brit. Zool. 54.

These are found in great numbers on all the coasts, especially those of Shetland. They are seen at.certain times in the mouth of Hoy Sound, and no doubt elsewhere round the country.

They seem to be very frolicksome, jumping about and tumbling at a strange rate, sometimes very high above water. All authors agree these are very voracious fishes; Sir Robert Sibbald, in his Phalainologia, gives us many observations on their fierceness. He tells us the whales, these vast animals whose bulk and strength, one would imagine, would secure them from all attempts from the brutal creation, are not safe from this far from despicable enemy, who will fasten on them, and make them roar like baited bulls. He observes, that they may be the occasion of so many whales being thrown ashore; that, flying from their avowed enemy, they run themselves unawares into the shallows, or kill themselves on the rocks.

The length of this species is various, being from fifteen to twenty-five feet, very thick in proportion, one of eighteen feet, as Mr Pennant tells us, being in the thickest place ten feet in diameter.

The nose is flat, and turns up at the end ; there are thirty teeth in each jaw ; those before are blunt, round, and slender, 
the farthest sharp and thick ; between each is a space adapted to receive the teeth of the opposite jaw, when the mouth is closed.

The spout-hole is in the top of the neck. In respect to the number and site of the fins, it agrees with the dolphin, which has a high triangular back-fin, placed rather nearer the tail than the head, and the pectoral fins low.

The colour of the back is black, but on each shoulder is a large white spot; the sides marbled with black and white; the belly of a snowy whiteness. Sir Robert describes others that were black, except the belly, and a spot on each shoulder; so that it is probable the colour alters in different subjects, or in age, sex, or other accident. 


\title{
DIVISION II.-CARTILAGINOUS FISHES.
}

\author{
Amphibia nantes,-Lin. Sys.
}

General Characters. - Instead of bones all these are furnished with cartilages, whence the name; they breathe through a set of apertures, differently constructed from the gills of fishes, properly so called. In their parts and methods of generation they differ; maribus pene duplici instructis; many of them are viviparous, being excluded from an egg, as in the sharks and rays. The whole general appearance (especially in the sharks and some others), is hungry and forbidding, which at once distinguishes them from the other fishes.

\section{GENUS IV.-THE SKATE, OR RAY.}

Gen. Char.-Body broad, flat, and thin ; five apertures on each side, placed beneath ; mouth situated quite below.

* With Sharp Teeth.

Species 1.-The Skate.

The Skate or Flaire, Wil. Icth. 69. Raii Syn. Pisc. 25. Raia Batis, Lin. Sys. 395. Brit. Zool. 62. Sib. Scot. 24.

Skates of all sizes are caught at the fishermen's hooks round these islands, from the breadth of an eating-plate to 
several feet. The colour of the back is a brown, shaded with clouds of a darker colour; the lower side is white, and spotted with black ; in some there are lines running, as it were, under the skin, and appearing through it, ending in a black spot; the tail has two fins, and pretty numerous spines, though not so many as in the thornback, or some others of the genus; the jaws are quite filled with sharp-pointed teeth, the roots of which are very thick, fastened in a sort of muscular skin, which covers the whole lips.

The young, or, as the fishermen call them, the maiden skates, are very good eating, but when they grow large are coarse, and very ordinary, yet none are thrown away, but the largest are dried and eaten by the country people and poorer sort. Large skates are sold for six, eight, or tenpence a-piece, or according to their bulk.

\section{Species 2.-The Sharp-nosed Ray.}

Wil. Icth. 71. Raii Syn. Pisc. 26. Raia oxyrinchus, Lin. Sys. 395. Brit. zool.III. 64 .

I HAVE seen a specimen of this fish in the Orkneys, taken by our fishermen, agreeing with the description of it given by natural historians. Those I saw were very large and much spotted; the nose longer and much sharper than that of the common skate, and the belly whiter.

Rays of all shapes and dimensions are here called Skates, 
or thornback skates, only the young of all are called maidens.

** With Blunt Teeth.

Species 3.-The Thornback.

Thornback, Wil. Icth. 74. Raii Syn. Pisc. 26. Raia clavata, Lin. Sys. 397. Brit. Zool. 69. Raia, the Thornback, Sib.Scot. 23.

Among the most ordinary captures of our Orkney fishermen; has its name from the many rows of thorns, or spurs, on its back and tail. It is so common that every one knows it ; while not too big is fine eating; but all the rays as they increase in bulk, turn very coarse and strong food, some of the largest little better than horse. Skates of all kinds are taken on the ordinary fishing-grounds round the Orkneys, but, like other flat fish, are most frequently met with in the eddies of the tides, or where two tides meet; especially when the tides run strong, they are obliged to withdraw to these calmer spots, their shape hindering them to sustain themselves against the force of the current.

I imagine the thorns on all these creatures increase both in number and bulk as they grow old ; for in a young thornback there are but few large spines, but the rudiments of more may be seen about to succeed; and whether there is any order in the spines of the back and breast I know not, as those I have 
examined differed in many particulars, even in fish of the same size.

\section{GENUS V.-THE SHARK KIND.}

Gen. Char.-Slender body, growing less towards the tail; two fins on the back; rough skin ; five apertures on the sides of the neck; mouth generally placed far beneath the end of the nose; the upper part of the tail longer than the lower.

* Without the Anal Fin.

\section{Species 1.-The Piked Dog-Fish.}

Galeus acantheus sive spinax, Wil. Icth. 56. The Piked-Dog or Hound-Fish, Raii Syn. Pisc. 21. Squalus acanthias, Lin. Sys. 397. Sib. Scot.29. Brit. Zool. 77. Orc. Hoe.

The Piked Dog-Fish, in its rambles through the seas for prey, often continues a short time on our coasts, and drives off every thing else. It is a gregarious fish, and sometimes comes in such shoals that the sea is covered, and our fishermen load their boats to the water's edge. They are very valuable to the captors; the fish is dried and eaten, and the liver yields a great deal of oil, fit for and used by all the country people in their lamps; the skin is used to polish wood, as also the fins, and the garbage makes excellent manure. 
The piked dog has his name from two sharp spines placed before his back fins, which are a sort of weapons of defence he can make good use of ; when caught, he writhos himself around the fishermens hands, often, if they are not attentive, wounding them very severely, which, if it happen in a part near a joint, is always dangerous and bad to heal, making the part swell, and look very red and fiery, and often endangering a gangrene. Whether this proceeds from any vicious juices about these spines, or from the violent dilaceration of the parts, which may affect them otherwise than an ordinary cut, I am unacquainted, and must submit to those better acquainted with the nature of wounds : but however it is, our fishermen always fear these dreadful weapons, and when the fish is hooked and brought up, commonly catch it by the tail, and, with a smart jerk against the edge of the boat, disable it.

\section{** With the Anal Fin.}

\section{Species 2.- The Basking-Shark.}

Squalus maximus, Sq. dentibus caninis, pinna dorsali anteriore majore, Lin. Sys. 400. The Basking Shark, Brit. Zool. 78. Orc. Hoe-Mother.

THIs is the most common species of the larger Sharks found in these seas. It is frequently seen in the harbour of Stromness, and other creeks of these isles, and in the open sea. 
[Fishes.

Some time ago one was observed for a whole day in the harbour of Stromness, and in that time went slowly round it several times, allowing the children to come close up to him in boats, without seeming in the least disturbed; every now and then setting up his large back-fin, and sometimes having great part of his back above water. In this manner he proceeded, without the least disturbance, till several boats were manned, and went after him with harpoons and lances. He allowed them to come close up with him, and two of them struck him, when, indeed, he made the water foam around him, tumbling about with vast violence for a few minutes ; he then dropped to the bottom, and they imagined he had been dead, and attempted to pull him ashore, for which purpose they got the assistance of nine boats, with their crews, who, with united force and much struggling, raised him up, and when he came up one of the people wounded him with a lance. This effectually rousing him, set him a running, and, in spite of the efforts of the whole people in the boats, about forty in number, he dragged the whole after him, till the harpoons came out of him, and he was given over for lost. In a little time he appeared again, and notwithstanding of what he had met with before, suffered himself again to be wounded with three harpoons; one of which near his breast-fins. This set him again a tumbling and beating the waves, driving the boats about him with his tail like as many chips ; but at last, repeating the efforts, and piercing him with many wounds, he was dragged ashore, and quite killed. 
The length of this fish was 23 feet, from the nose to the point of the tail ; the girth round the belly about sixteen; the snout short, being about a foot over the mouth, blunt and pierced full of small holes; the mouth large, not shaped like the dogfish kind, but liker those of the fishes, $i$. e. with two extended jaws; the eye was small, placed within about two inches of the rictus of the mouth, in the upper lip; the teeth small, in five or six rows, were all so loose that they might be moved with a finger; there were five large openings, reaching from the neck to the throat, answering to the gills of other fishes; within the mouth might be seen the gills, fringed with a sort of small bristles approaching the nature of whalebone; the first back-fin very large, being about four feet high ; the next less, being something more than a foot; the tail was four feet long, and six feet between the tips, which were equal in length, only the upper was something broader and blunter than the lower, and not so as in most sharks, with the upper half longest ; the pectoral fins were near four feet long; the ventral two and a half, with two genitals three feet long each; the anal fin was fifteen inches high; these fins all shaped like others of the shark-kind, having a long and sharp process next the body. The stomach was full of a red stuff, like bruised crabs, or the roe of the sea-urchin, but no fragments of fish could I find in it; and, indeed, both its appearance, manners, and weapons, do not indicate it to be a ravenous fish. When the liver was taken out it loaded a small boat, and contained something more than six barrels of oil ; this being a male, did not give so much as a female would. I was told of one 
[Fishes.

of the same kind, caught in a neighbouring island (by throwing the running noose of a rope over the pectoral fins, and playing it), which measured twenty-eight feet, out of the liver of which they had twelve barrels.

The flesh looked partly like beef and partly like turbot; it was cut in pieces, and much of it eaten by the poor people. The colour of the whole fish was black, something lighter and inclining to dusky white on the belly.

Some of the sea-faring people called it Sun-fish, others Carfin : in Orkney it is called Hoe-Mother, or Homer, i. e. the mother of the dog-fish.

I suppose it is the same with what is described in the British Zoology under the title of Basking-Shark, though it is there placed in the division of sharks without the anal fin; however, Mr Pennant tells us in the appendix, p. 342, this might have been overlooked. The above had it as described, which has induced me to remove it from that section of sharks, and place it at the head of those which frequent our seas, and have the anal fin.

\section{Species 3.-The White Shark}

White Shark, Wil. Icth. 47. Raii Syn. Pisc. 18. Squalus Carcharias, Lin. Sys. 400. Sib. Scot. 23. Brit. Zuol. 82.

IT never came in my way to see or examine this fish, but am credibly informed it is found in the seas round these isles, 
and instances have been given me of its being drove ashore here. The most dreadful of all the shark-kind ; its mouth armed with terrible teeth, and these in vast numbers, so that nothing can escape it which is so unhappy as come within their grasp.

When these fall in with our fishermen's lines they make vast havock among them, by devouring the fish; and if they happen to be caught on a hook, by twisting the lines to pieces, or sometimes pulling them away with them. In a word, it is a most destructive fish wherever it comes, but happily is but seldom seen on our coasts.

\section{Species 4.-The Lesser Dog-Fish.}

Lesser Rough Hound or Morgay, Raii Syn. Pisc. 22. Wil. Icth.64. Squalus Catulus, Lin.Sys. 400. Orc. Daw-Fish, Brit. Zool. 90.

TH Is species is caught in small quantities on our coasts. Like all others of the genus they seem to be migratory, but stay longest with us of any of them, insomuch that, through the whole summer, single fish may be caught with us. This species is little valued either for eating or for oil, so that the fishermen seldom give themselves much trouble about them.

All the dog-fish bring forth their young alive, or at least the greater part of them, some bringing more, others fewer at a time: I have of these, cut out of the bellies of the dams, with the egg still hanging at them. This was in July, which makes 
me think they bring forth pretty late in the year, as these did not seem near ready to be excluded; those I saw were of the piked dog. Others cast their purses, called here Crow-purses, in which I suppose their young are included; but with the generation of these I am not so well acquainted, having examined several of them, and found nothing like the rudiment, and only full of a sort of milk.

\section{GENUS VI.-THE STURGEON.}

Gen. Char.-One narrow aperture on each side; the mouth placed far below, tubular, and without teeth; the body long, and often angular.

Species 1.-The Sturgeon.

Sturgeon, Wil. Icth. 239. Raii Syn. Pisc. 112. Accipenser Sturio, Lin. Sys. 403. Brit. Zool. 96. Brit. Zool. Illus. 74. tab. 89. Sib. Scot. 25.

The Sturgeon has a place here upon the authority of $\mathrm{Mr}$ Wallace and others, who say they are drove ashore upon our rocks. I never saw any of these, but heard of one which came ashore in one of the north isles of Orkney some time ago. Upon the whole, I believe it is but a stray fish of this kind that is ever seen in the Orkneys. 


\section{GENUS VII.-THE LUMP-FISH.}

Gen. Char.-Thick body; arched back ; ventral fins united; four branchiostegous rays.

\section{Species 1.-The Lump-Fish.}

Lump or Sea-Owl ; Scotis, Cock-Paddle, Wil. Icth. 208. Raii Syn. Pisc. 77. Cyclopterus Lumpus, Lin. Sys. 414. Lumpus Anglorum, nostratibus the Cock-Paddle, Sib. Scot. 24. Brit. Zool. 103. Brit. Zool. Illus. 28, tab. 29, fig. 1, 2. Orc. Padle.

The Padle, as it is here called, is very frequent in our harbours, especially on the sand-banks, where I have seen half a dozen drawn ashore in a net at once, but never of any great bulk. It is an oddly-shaped creature; the back rises into a sort of hunch, on which is a part something resembling the comb of a cock; the side of the belly and sides have rows of hard tubercles, running along them towards the tail ; the whole skin is rough, and the colour of those found in our harbour is black on the back, and greenish on the belly; whether they change colour as they increase in bulk, I know not.

The most curious part of this curious fish is a hollow under the pectoral fins, by which it adheres with great firmness to the stones, or any thing else where it can fix itself, so that when once it is fixed there is no removing it, and the stone 
may sooner be moved than it pulled away. This part, I imagine, acts much in the same manner as the circular piece of wet leather, which children use to run a string through the centre of, and clapping it on a stone, by the action of the air it is held with great force, so as to lift a very large stone, and sustain it as long as the leather continues moist, and the outward air is excluded by its closely embracing the solid body.

\section{Species 2.-The Sea-Snail.}

Liparis nostras Dunelm. et Eborac. Sea-Snail, Wil. Icth. App. 17. Raii Syn. Pisc. 74. Cyclopterus Liparis, Lin. Sys. 414. Brit. Zool. 105. Brit. zool. Illus. 28, tab. 29, fig. 3, 4.

TuE Sea-Snail is found under the stones round the shores of many places of Orkney, but no place more frequent than that at the point of the Ness of Stromness, where they may be picked up in dozens.

The colour is a fine pale brown, stripped with lines of a darker brown, which run in many directions, forming a vast variety of labyrinthiform figures on its sides and back; but these are only seen immediately on its being taken out of the water ; in half an hour they all vanish, and with them the beauty of the fish, owing to the quick decay of its melting texture.

The head is large; no teeth; the pectoral fins unilc under the throat, and under them is a sucker, something similar to, 
and serving the same purpose as that observed in the lumpfish ; the dorsal fin runs from the hind part of the head to the tail; the anal the same below; the measure of those $I$ have observed in these parts seldom exceeds four inches, though many of them are not so large.

\section{GENUS VIII.-THE PIPE-FISH, OR SEA-NEEDLE.}

Gen. Char.-Nose long and tubular; no orifice to the gills; the breathing apertures on the hind part of the head; no ventral fins; the body covered with a strong crust.

\section{Species 1.-The Longer Pipe-Fish.}

Acus nostras cauda"serpentina, Sib. Scot. 24,tab. 19, fig. 3. Syngnathus barbarus, Lin. Sys. 417. Brit. Zool. 106, tab. 6, fig. 2.

I IIAVE had occasion to see great numbers of these fishes, but all dry, therefore shall describe it from the British Zoology, and Sir Robert Sibbald's Prodrom. Nat. Hist. Scotiæ, giving the measurement of the different parts from specimens in my own possession, as I never saw, nor had one so long or thick as described either by Mr Pennant or Sir Robert Sibbald. The largest I ever saw on our coasts, measured, from the nose to the point of the tail, twelve inches; to the eye half an inch; to the beginning of the back-fin four inches; 
[Fishes.

the back-fin, which was all it had, one inch and three quarters long; from the end of that fin to the point of the tail six inches; the body about the thickness of a pretty large quill; the nose was compressed sidewise; the end of the lower mandible turned up; the aperture of the mouth very small.

The irides were red; behind each eye was a deep brown line.

The body was angular, but the angles not very sharp, and not easily seen till the fish was dried; the belly was slightly carinated, and marked along the middle with a dusky line.

The general colour of the fish was an olive brown; the sides marked with bluish lines, pointing from the back to the belly, which, in a dried fish, looked like the signs of so many joints. Those in a fresh subject ceased beyond the vent; all beyond that was spotted with brown; the dorsal fin was narrow and thin, consisting of thirty-eight rays.

The vent (in mine) was five inches from the nose ; the body to that was of an equal thickness, but from thence tapered to a very small point, having no mark of a fin.

It was covered with numbers of angular crusts, finely radiated from their centre; but these do not appear so well in this as the next species to be described.

$\mathrm{Mr}$ Pennant adds, they are viviparous, and hundreds of minute young ones had been forced out of one of them. 
The Pipe-Fish.]

Species 2.-The Shorter Pipe-Fish.

Acus Aristotelis seu secunda, Wil. Icth. 150. Raii Syn. Pisc. 47. Syngnathus acus, Lin. Sys. 416. Brit. Zool. 108, tab. 6.

THIs species is still more frequent than the former, and is found of many sizes, from six inches to fifteen and a half, from one of which last dimensions I shall give the following measures and description.

The snout, from the nose to the eye, an inch and a half; to the covers of the gills something more than two; to the beginning of the back-fin six inches and a half; the back-fin two inches long; from the end of it to the tail seven inches and a half.

The snout is pretty much like that of the former species ; the gills not open below as in other fish, but on each side of the neck is an aperture pointing upwards; the pectoral fins are placed much as in other fishes.

The body, from the head to the vent, is heptangular, from thence to the end of the back-fin hexangular; from the end of the back-fin to that of the tail, quadrangular; the fins are five in number, viz. the two pectoral ; the single back-fin; the tail, which in this is finned, not, as in the last, pointed ; a very minute anal fin, consisting of a single ray (my specimens were all dry, so that I cannot be positive of the rays, but of the existence of the fin I am certain, as it was in them all), about an eighth of an inch long. 
[Fishes.

The whole body is covered with strong crusts, prettily radiated from a centre; the number of these, from the pectoral fin to the tail fin, sixty-five.

The back of a large specimen was brown spotted, the belly whitish ; that of a smaller, light brown, the belly white.

Species 3.-The Little Pipe-Fish.

Acui Aristotelis congener pisciculus, pueris Cornubiensibus Sea Adder; acus lumbriciformis, aut serpentinus, Wil. Icth. 160. Raii Syn. Pisc. Syngnathus, ophidion, Lin. Sys. 417. Brit. :ool. 109, tab. 6, fig.3.

Turs is the smallest of the genus, and found very frequently under stones in the space between high and low watermark; liker the first than the second species, only the nose is shorter, and turns more up; the fins are the same number in both, but the body of this is not covered with crusts, as in the former, but with a skin; the colour of those I have seen was a deep olive green.

These needle fishes are of no use here ; they are never eaten, and the coat of mail wherewith they are covered hinders them from being made bait, for no fish will be ready to snap at a creature so well defended. 


\section{ADDENDUM.}

\section{The Fishing-Frog.}

\section{Brit. Zool. 93.}

This species is sometimes cast on shore at Foula, but nowhere else (that I can hear) among these islands. 


\section{DIVISION III.-FISHES FURNISHED WITH HARD BONES.}

These are divided into Apodal, Jugular, Thoracic, and Abdominal, which names are taken from the want or situation of the belly.fins.

\section{Apodal.-Belly-Fins.wanting. \\ GENUS IX.-THE EEL.}

Gen. Char.-Body long, slender, and slippery ; nostrils tubular; back, anal, and tail fins united; aperture to the gills small, and placed behind the pectoral fins; ten branchiostegous rays.

\section{Species 1.-The Common Eel.}

The Eel, Wil. Pisc. 109. Raii Syn. Pisc. 37. Muræna Anguilla, Lin. Sys. 426. Brit. Zool. III. 111.

EELS are very common in all our lochs, burns, and in the sea. They are found in many of our lochs, especially where no fish else are, and even in those whose efflux into the sea is over such precipices as to allow of no passage for any living thing, which puzzles many of our country sages to account for their getting there ; and indeed this is no easy task, if we do not consider the manners of the eel; how difficult it is to 
be retained in the claws, or even the stomachs, of birds which prey on it ; how tenacious of life it is, which makes it capable of being carried a great way without being the worse ; and if dropped, its ability in this case to seek out a proper habitation for itself.

The mind of man, once set upon scrutinising any particular, can ill bear to be baffled, but must solve it in some manner, though frequently false; no wonder then there have been so many odd opinions, relative to the furnishing the remoter lakes with eels. Our rural philosophers, not perhaps so attentive to every one of the eel's faculties, have found out a method of supplying all the lakes in the world with eels, by a very easy expence:-nothing more than throwing into the water a few hairs of a stallion; and of which they tell us all these eels come, which are found in these inaccessible places. But ask reasons for thinking so, -all dumb!

Eels seldom are seen here of any great bulk; two feet and a half is the largest $I$ have seen, but few even of that size. At particular times of the year, they may be caught in hundreds in the harbour of Stromness, especially immediately before the piers, - the receptacles of many a different animal, both land and sea.

The flesh of eels is something strong, and the skin thick, and very tough. Our country people strip it off, and wear it about their ankles as a preservative against the cramp; with what justice it deserves that character I know not, or whether the effects are answerable to the expectation.

Eels were long thought to want scales, but this is found to 
be a mistake ; these, however, are not placed in the manner of those of the other fish, but are included in a common covering, or scarf-skin ; neither do they, like others, fold over one another, but are placed close together, as nearly as possible, without folding. Let any man take a bit of eel's skin, and wipe the slime clean off, or, if dry, moisten it in a little warm water, and place it before a good microscope, when he will soon be convinced of this fish having scales, and these being placed in the manner foresaid. The structure of the scale too differs from those of all other fish I know ; but the description of this rather belongs to the writer on micrography than systematic ichthyology. I shall close this account of the eel, by observing, that it is very seldom eaten in the Orkneys.

\section{Species 2.-The Conger.}

The Conger or Conger-Eel, Wil. Icth. 3. Raii Syn. Pisc. 37. Muræna Conger, Lin. S, s. 420. Brit.Zool. 115. Sib.Scot. 23.

'THE Conger is found very frequent in the sea round these isles ; some are caught at the fishermen's lines, but the otter is by far the most successful in killing congers. He brings them ashore, and eats but a very small part, leaving the rest for the next comer; and where his haunts are known, the country people are very careful every morning to search for the remains of the night, and are seldom disappointed, but find cod, 
ling sometimes, but especially congers, which are oftener seen amongst the deep hollows of the rocks than farther to sea.

They are never caught in such a quantity as would be worth while to cure, or send to a market; and if they were, our people have no method of curing them.

The largest conger I ever saw here measured about six feet, but probably there may be larger ones caught; Mr Pennant records some that were got on the coast of England ten feet and a half long, and eighteen inches in circumference in the thickest part.

\section{GENUS X.-THE WOLF-FISH.}

Gen. Char.-Blunt head; long body; one dorsal fin, reaching almost from head to tail : fore-teeth conic, and larger; grinders flat and round.

\section{Species 1.-The Sea-Wolf.}

Cat-Fish, Sib. Scot. III. 25, tab. 16. Wolf-Fish, Sea-Wolf or Woof, Wil.Icth. 130. Raii Syn. Pisc. 40. Anarhichas Lupus, Lin. Sys. 420. Brit. zool. 119, tab. 7, vol. 3. Orc. Swine-Fish.

This very dreadful and ugly fish is often caught in our seas, and sometimes thrown ashore in storms. None of our fishermen love it, either hating the colour or the great teeth, 
of which it can make good use, even when out of its own element.

The mouth of this fish is furnished with the most dreadful weapons of any in our seas; the jaws with broad and strong grinders ; the fore-teeth long, conical, and sharp; the roof of the mouth is not without its share of armour, and has many flat teeth in it, all excellently fitted for bruising the hardest food.

The fish is excellent eating; however, none are very fond of it, and generally reject it. The Orkney name, Swine-fish, is taken from a sort of muscular motion in the nostrils of this fish, which our fishermen say resembles that in the nose of swine.

\section{GENUS XI.-THE LAUNCE.}

Gen. Char.-Head slender; body long and square; upper lip doubled in ; dorsal fin and anal reaching almost to the tail; seven branchiostegous rays.

\section{Species 1.-The Launce.}

Ammodytes Gesneri, Wil. Icth. 113. Sand-Eels or Launces, Raii Syn. Pisc. 38, 165. Ammodytes Tobianus ${ }_{2}$ Lin. Sys. 430. Sib.Scot.24. Orc. SandEel. Brit. Zool. 123, tab.8.

Tris beautiful fish is to be found in vast quantities, at particular times of the year, in the heaps of sand thrown up by 
the tide, and in some places is taken up by a common corn hook; but here, though they are very frequent, are very little sought after, which is the more surprising, as no fish nıakes a better bait for the larger fishes, and besides is excellent eating.

This fish is most excellently shaped for its way of life; the head small, and muzzle sharp, to pierce through the sand easily; the body square and slender, so that there may be no obstruction from it; in a word, the whole shape is fitted to make way-very quickly through the sand, to save itself from its many enemies, for few fish that take a bait but may be caught at a hook baited with sand-eel or herring.

The colours of this fish are very bright; the back in some blue, in others green; the sides and belly of silver white; the skin so thin that the partings of the fish may be seen through it ; the side line visible and straight.

This fish makes a very fine dish, and when in roe, this taken out and fried is excellent. It seems sensible of its own excellency, and the many enemies it has to fear, for if at any time it comes up out of the sand, it immediately, as if conscious of danger, hastes to bury itself again. Porpoises, cod-fish, 'mackerel,' and many others, are continually hunting after it while the tide is up, or in the deeper waters; and the seabirds are very careful watchers of it while the tide is low.

We have another silver-coloured eel, found very frequent among the ware at low-water mark; but as the shape differs from the former, I rather imagine it may be the young of the common eel, as they are never seen of this colour above two or three inches long, and of the thickness of a crow quill, 
almost quite transparent, the back-bone, heart, and other bowels distinctly seen. This makes an excellent object in the microscope, for viewing the circulation of the blood.

2. Jugular.-The Ventral Fins before the Pectoral.

\section{GENUS XII.-COD-FISH KIND.}

Gen. Char.-Head smooth; seven slender branchiostegous rays; body oblong; scales deciduous; all the fins covered with a common skin ; ventral fins slender and ending in a point; teeth in the jaws, and in the palate a series of very minute teeth, closely set together.

* With three dorsal fins; the chin bearded.

\section{Species 1.-The Common Cod-Fish.}

Asellus major vulgaris, Wil. Icth. 165. Cod-Fish or Keeling, Raii Syn. Pisc. 55. Gadus Morhua, Lin. Sys. 436. Brit. Zool. 137. Orc. Cod or Codling.

The Cod-fish is so well known as to need no description ; is found in swarms on the banks all round these coasts, but very little sought after. Of old this was not the case. In Walls, in Birsa, in Græmsey, and many other places, men and boats were stationed, who made it their constant employment to catch fish for curing and sale; merchants from the south 
had their factors, \&c. here, and many fish were yearly made and transported from these isles, to the great advantage both of the seller and buyer. Now all is sunk is sunk in indolence and sloth,-with but faint hopes of our soon emerging from it.

The cod-fish is very voracious; devours every thing eatable; often shifts its ground, either for conveniency of prey, or to shun the dog-fish, which often come in shoals, and sweep the ground of everything living. The cod is the most prolific of any fish in these seas, and is commonly found high in roe in April, and a few in the beginning of May, at which time their quantity of roe is surprisingly large, and the eggs being very small, must give birth to an immense number of fry.

Mr Lewenhoek's calculation of nine millions three hundred and eighty-four thousand eggs, though a surprising quantity, is, I dare say, much within truth, as to the spawn of these fish in general ; and yet, notwithstanding of the numerous myriads that must arise from these, we very seldom see many of the fry, so that I suppose their growth is sudden, and their place, till arrived at some bulk, the deeper waters.

Cod are found of very different shapes and colours, and even the taste differs according to the place they feed in.

They are often, when poor, tormented with a sort of worm, which insinuates itself into the flakes of the fish, and there lies in many folds; but this is never seen in a cod while in season.

The best places for the fishery of cod on these coasts, are the banks to the north-west of the Burgh of Birsay, the eddies in the Pightland Frith, round the east side of Orkney, in the Ger- 
man Sea, and, in a few words, very few places on the northern coasts of Scotland, where a ship or boat can ride safely, but cod may be got in quantities, and these sizeable, besides other fish in plenty.

\section{Species 2.-The Haddock.}

Haddock, Wil. Icth. 170. Raii Syn. Pisc. 55. Gadus Eglefinus, Lin. Sys. 435. Brit. Zool. 144. Sib. Scot. 23.

Thrs species is not so frequent on the coasts of Orkney as cod-fish, nor are they caught in any quantity; they seem only to visit us by the bye, and to make no great stay. A few very fine ones are got in the west sea, but very seldom can they be got in season, owing to the stormy weather on our coasts in their time. A few are got in summer in Hoy-Sound, and through the other tide-ways of Orkney, especially the southeast corner of it ; but these are but small and poor.

Perhaps, indeed, our fishermen have not the method of catching haddocks, which makes us imagine them scarcer than they really are. However this may be, very few hadocks are got in a year in the Orkneys. 
* * Three Dorsal Fins; Chin Beardless.

$$
\text { Species 3.-The Coal-Fish. }
$$

Cole-Fish septentrionalum Anglorum. Rawlin Pollack. Cornubiensium, Wil. Pisc. 168. Raii Syn. Pisc. 54. Gadus carbonarius, Lin. Sys. 438. Brit. Zool. 152. Brit. Zool. Illus. 29, tab. 33. Sib. Scot 23. Orc. * Seth, Kuth or Silluck, Piltock or Cuddin $\uparrow$.

As things are at present with us, this species is the treasure of the Orkneys ; while these are to be found, none else are regarded.

The fry of the coal-fish appear first with us in May, but small quantities, and themselves very small. About August they begin to be taken with small rods in great numbers, but still this is nothing to the shoals that set in towards winter, when the sea begins to grow stormy; then the harbour of Stromness especially, and many other places, are quite filled with them, and thus they continue for the whole winter. About this time they measure from six to ten inches, and are very much esteemed; all ranks and ages eat them under the name of Sillucks. About March, the shoal, or what is left of them, begin to retire to the deep, and grow very fast, insomuch that, though perhaps not above eight or ten inches when they

* Vide Sib. Scot. Illus. P. II. Lib. 3, p. 28. In boreali Scotia plaga, the Seath-Fish.

+ Vide Addend. Sib. Scot. p. 37. Cet. ad finem. 
[Fishes.

go out in March, yet in May, when another fishing of them begins, under the name of kuths, they are fifteen; still they are tolerable for eating, either fresh, as our Orkney folks eat them, roasted with the liver, or dry. A few of the same shoal are caught next year, when they are called Harbines, or two year old kuths, but they are now large and coarse, and not much sought after. After this they grow to a vast bulk, and are then called Seths; but very few of these are found here, not perhaps one in a season : they retire farther to sea, and are got in some quantities on the coast of Shetland.

In the winter-time, while the fry of this fish is in the harbours, it is common to see five or six hundred people, of all ages, a-fishing them, with small angling rods of about six feet long, and a line a little longer; but with this simple apparatus they kill vast numbers, none going away without as many as he inclines. The whole harbour is covered with boats, and the piers with men, and all are supplied; for from the surface to the bottom of the water it is crowded.

5. It is very certain these fish are of vast service to Orkney, as things are ; because children of a few years old, that can be of no other: service, and old age that is past it, can all wield the silluck rod, and in a few hours kill as many as serve moderate family for a day, and sell some, which is commonly done from thirty to sixty or more for a halfpenny. Yet, I say, though in our present circumstances these small fish are the most valuable we have, yet I know not if this is the case all things considered; for, in the first place, they encourage laziness in our fishermen, who, when they are to be found, never trouble 
themselves to seek any thing better : next, all other fisheries being neglected, the fish withdraw from our coasts, having nothing to detain them : for I am fully persuaded, that the more a fishing is followed, and the greater care taken to clean and throw overboard the garbage, the more fish will be drawn to the ground, and of consequence the fishery will be more valuable. But all these things are neglected; and, instead of leaving children, and those who are not able to go further to sea, to fish at home for subsistence, bait, \&c. whilst the abler men go to sea, all hands go to work in their boats, and destroy these fry in such quantities, that sometimes more spoil than are made use of. However, this is not to be remedied as things are, for there are many discouragements to hinder the fishermen from following a fishery of the larger kinds, such as a want of a proper method in conducting their fishing; - want of proper markets to bring their fish to, which cannot be sold, were they to get any quantity, to any purpose here;-want of ability to send them to market;-and want of ability to spare the price of them till they could be sent:-all which is obviated in their small fishing, for what they can spare they have an immediate market for amongst their neighbours, which serves their present purpose better than labouring for cod and ling, which they must either keep, or sell below what is worth their trouble. From this short view we may see the state of fishing in Orkney; we may see, at the same time, that, till some set of public-spirited gentlemen, merchants, or other monied-men, take into their hands, and draw our fishermen out of their present indolence, - en- 
[Fishes.

courage them to go to: sea, - send their produce to market, and make them proper returns,- - we must not hope to see fishing flourish in the Orkneys, which, from their situation, might be both valuable for the fish, and for an inexhaustible nursery for hardy and experienced seamen.

\section{Species 40-The Pollack.}

Assellus Huitingo-Pollachius, Wil. Icth. 16\%. Whiting Pollack, Raii Syn. Pisc. 53. Gadus Pollachius, Lin. Sys. 429. Orc. Lyth or Ly-Fish.

These are not found so common as the others, yet are frequently caught close in with the shore, almost among the sea-ware, and in deep holes amongst the rocks. They seem to be a very frolicksome fish, as is observed by the natural historians*. I have been several times fishing them, when they would keep a conștant plashing on the water. They bite keenly, scarce allowing the hook to be in the water, before one or other jumps at it.

They are better for eating than the coal-fish; but do not know whether they are ever dried or preserved otherwise, as the quantity caught is scarce worth curing.

The general appearance of this fish is like the former, only the back, as it comes out of the water, is a most beautiful green, but it soon loses that colour; the side line is much crook- 
ed in this, bending towards the back, whereas it is pretty straight in the former. The sides are yellow; the belly white.

\section{Species 5.-The Whiting.}

Assellus mollis major, seu albus, Wil. Icth. 170. Whiting, Raii Syn. Pisc. 55. Gadus Merlangus, Lin.Sys. 438. Sib. Scot. 23. Brit. Zool. 155.

I CANNOT deny this fish a place here, because $I$ have seen it once or twice caught in these seas, but, for ought I can be informed, it is very infrequent. I suppose it can scarce bear the rough gusts of our winter seas, being a very delicate fish *. $\mathrm{Mr}$ Pennant tells it is found on the Dogger-Bank, which would make one imagine it would sometimes visit our shores. $\mathrm{Mr}$ Wallace takes notice of the whiting in his short catalogue of Orkney fishes, but does not say whether got in his time in quantities or not.

* When haddocks are caught in any quantity with us, whitings are got in numbers. 


\section{With only two Dorsal Fins.}

\section{Species 6.-The Ling.}

Ling, Wil. Icth. 175. Raii Syn. Pisc. 56. Gadus Molva, Lin. Sys. 439. Brit. Zool. 160. Sib. Scot. 23.

This, next to the coal and cod fish, is the most frequently found of any fish on the Orkney coasts; but, like the cod-fish, the fishery is neglected. I have seen some inconclusive trials made of the fishing of these, when a number of good sizeable fish were got; but this.dropped away to nothing. Ling-livers are valuable for the oil, and are sometimes eaten, though not always without danger, say. our country people, which is most apparent when the liver is discoloured, or the fish out of season. Ling-fish are caught upon what our people call great lines, or a line with several hundred hooks, placed at certain distances through the whole length of it, and these are baited and allowed to remain in the water all night, when the people in the morning examine what is caught, bait them again, and immediately reset them, though in the former part the dog-fish and other sharks are sometimes before-hand with them. Ling from the hook here are sold at about sixpence or eightpence apiece, but, when dry, at about fourteen shillings sterling per dozen. 


\section{Species 7.-The Whistle-Fish.}

Gadus Mustela, Lin. Sys. 430. Brit. Zool. 165. Brit. Zool. Illus. tab. 33. Orc. Red-ware Fishik.

THIs species is commonly found under the stones among the sea-ware, seldom exceeding nine or ten inches in length. The body is round to the vent, then becomes compressed; blackish brown on the back; a dusky yellow, inclining to white, on the belly; the mouth has five beards, four of which are placed above, and one below the chin; the first back-fin is very weak, and placed in a pretty deep furrow, which begins at the back of the head; the first ray of the fin is cirrhated; the second back-fin begins where the last ended, and runs almost to the tail ; the anal fin begins there, and in like manner reaches near the tail; the tail is round and reddish ; the scales small; and the whole body covered with a great deal of slimy humour.

These small fish are reckoned pretty good eating, but are never got in any quantity; never caught at a hook; the only method of getting them is by shifting the stones at low water, when they are to be found with the blennies. 
**** With one Fin on the Back.

Species 8.-The Torsk-Fish.

Orc. Tusk or Cat-Fish.

This fish is found on the banks off the Burgh of Birsay in small quantities, but is very frequent on the coasts of Shetland, where it makes a very considerable article in their fish trade. I am told the price has risen much within these few years, insomuch that fish which could formerly be bought for two shillings or two shillings and sixpence per dozen, now sell for a crown*, owing, I suppose, to the extensive demand for it. It is one of the best cured fishes, swells much in boiling, and parts into very thick flakes ; ate fresh is very firm, rather tough, which makes most people prefer it dry.

The description of this fish, which seems not to be that of the natural historians, is as follows : The head small in proportion to the fish, with a single beard under the chin; the upper-jaw very little longer than the lower; in the jaws there are great numbers of small teeth, and in the roof of the mouth a rough or toothed bone, much of the shape of a horse-shoe; a pretty broad furrow runs from the setting on of the head, to where the back-fin begins, which runs the whole length of the back, within about an inch of the tail; the tail is rounded; anal

* Torsk now sells for thirteen shillings and sixpence a quintal, in Shetland. 
fin begins at the vent, and ends at the tail, but is not joined with it ; the rays of the back and anal fins are numerous, but the softness of these, and the thickness of the skin, hinders them from being counted with exactness; the points of the back-fin, anal, and tail, are white, the rest dusky ; the pectoral fins are rounded, broad, and of a brown colour; the ventral small, thick, and fleshy, ending in four points, or cirrhi ; the body, to the vent, is roundish ; the belly, from the throat, growing suddenly very prominent, continuing so to the vent, where it grows smaller to the tail ; beyond the vent the body is pretty much compressed ; the colour of the head is dusky; the back and sides yellow, which, becoming lighter by degrees, loses itself in the white of the belly; the side line was scarce discernible, but run nearer the back than the belly, till about the middle of the fish it bent a little downwards, and run straight to the tail. The measures of the specimen from which this description was taken, were the following:-The whole length twenty inches and a half; the greatest breadth four and a half, which was taken at the end of the pectoral fin ; at the vent, four inches; something more than half way from the vent to the tail, two inches; at the tail, one inch and a quarter; the length of the head, four inches ; from the point of the nose to the beginning of the back-fin, six ; length of the back-fin, thirteen ; from the point of the lower jaw to the vent, eleven inches; the anal fin, eight ; tail something more than two.

There is no fish more common on the coast of Shetland than the tusk. It is there caught among the ling, and in apc c 
pearance differs not much from it, only it wants the first fin of the back, which the other has; nor does it grow the length of the ling, the largest tusk $I$ have heard of not being above three feet and a half long.

\section{GENUS XIII.-THE BLENNY.}

Gen. Char.-Head blunt at the end, and very steep; body smooth and slippery; teeth slender; body compressed sidewise; ventral fins consisting of only two united rays; one dorsal fin; six branchiostegous rays.

\section{Species 1.-The Spotted Blenny.}

Gunnellis Cornubiensium, nonnullis Butter-Fish, q. d. Liparis, Wil. Icth. 115. Raii Syn. Pisc. 144. Blennius Gunnellus, Lin. Sys. 443. Brit. Zool. 171. Orc. Swordick.

The Spotted Blenny is found very frequently under stones at the low water-mark, or above it, among the sea-ware. It is very tenacious of life ; can endure to want water almost for the time the tide is down. A coarse fish, and seldom eaten; used sometimes for bait, but this is only when the fishermen can get no better. This fish is seldom found above six inches long; the body much compressed, which has got it the name of Swordick, or Sword-Fish, in Orkney.

The back-fin begins near the head, and runs almost to the 
tail ; on the top of the back are ten round black spots, encircled with white, which reach the lower half of the back-fin, and one at the beginning of the tail.

The anal fin begins at the vent, and runs to the tail ; the tail is rounded, and of a yellow colour.

The colour of the whole fish is olive; the belly a dusky white.

\section{Species 2.-The Purple Blenny.}

The appearance of this is so much like that of the former, that I should almost take it for a variety, were it not that the colour is different, being in this reddish purple; the fins lightest, and of the same shape and size of the former. It likewise wants the spots on the back the other has ; instead of eleven in the former, this has only a single one, and that placed near the beginning of the back-fin. In other circumstances, both of its shape and way of life, it agrees altogether with the former. 
[Fishes.

\section{Species 3.-The Viviparous Blenny.}

Guffer or Eelpout, Sib. Scot. 25. Mustela vivipara Schonveldii, Wil. Icth. 122. Raii Syn. Pisc. 69. Blennius viviparus, Lin. Sys. 443. Brit. Zool. 172, tab. 10, fig. 1. Orc. Greenbone.

Found, with others of the genus, under stones, tang, \&c. at the low water-mark, in great numbers, from six inches to ten in length, but the thickness scarce proportionable, having an eel-like form; hence, I suppose, the name Eelpout.

It is not so coarse as the other blennies; the fish tastes much better, and fatter ; the back-bone is a most beautiful green, which gives it its Orkney name.

The colour on the back is a dirty yellow, clouded with brown and black; the sides lighter, and more inclined to greenish; the belly whitish ; the back-fin spotted.

The pectoral fins are broad, and rounded at the end; the ventral fins in this, as well as the rest of the genus, small and pointed ; the anal begins at the vent, and runs to, and unites with the tail; the colour yellow.

The tail is small, ends in a point something similar to that of an eel.

Contrary to the nature of other fishes, these bring forth their young alive, and ready to perform every function for the preservation of life. When I first observed this, I put a number of the small fishes in a tumbler-glass of sea water, and kept them alive for many days, changing the water every tide. 
They grew a good deal bigger, and continued very lively, till in a hot day, forgetting to refresh them with clean water, they died to the last fish.

Whilethey were very young and transparent, they made excellent objects for the common microscrope, for viewing thecirculation of the blood; do not answer well in the solar, as the heat of the enlightening lens soon kills them, or renders the skin dry and opaque, thereby hindering much the effect of that most surprising instrument.

3. Thoracic Fish.-The Ventral Fins placed beneath the Pectoral.

\section{GENUS XIV.-THE GOBY.}

Gen. Char,-Eyes placed near each other; four branchiostegous rays; ventral fins united.

\section{Species 1.-The Black Goby.}

Sea-Gudgeon, Rock-Fish, Wil. Icth. 206. Raii Syn. Pisc. 76. Gobius niger, Lin. Sys. 449. Brit. Zool. 174. Orc. Black Rock Fishick.

THe Black Goby is found pretty frequent among the deep holes about the point of the Ness of Stromness ; seldom seen here above three or four inches long; the colour blackish, or 
inclining in some to brown. It is little regarded here ; its bulk renders it no object for eating, or any thing else*.

\section{GENUS XV.-THE BULL-HEAD KIND.}

Gen. Char.-Large flat head, armed with sharp spines; six branchiostegous rays.

\section{Species 1.-The Father-Lasher.}

Scorpænæ Bellonii similis Cornub. Father-Lasher, Wil. Icth. 158. Raii Syn. Pisc. 145. Cottus Scorpius, Lin. Sys, 453. Sib. Scot. 24, tab. 17, fig. 1, 2. Urc. Comper.

ThIs fish is found in every pool into which the sea regularly flows, lurking under stones, and under the points of the rocks, watching for any small fish to make its prey of it. The most formidably furnished with armour of defence of any our fishes.

The head and mouth are very large, armed with sharp spines, as are the covers of the gills. These it has a power of erecting, by blowing out its cheeks, and this it does immediately upon its being caught. I once saw a trial of skill between a large one of this kind, and a cormorant. The latter

* The Spotted Goby occurs in the same places with the other.-Note in a dif: ferent hand-zoriting. 
got the head and part of the body of the fish swallowed, but being wounded by the spines, I suppose, attempted to bring it up again ; however, this was not practicable, for these being placed the contrary way, hindered its return, and acted the same part as the beard of a hook, in fixing it firmer in the throat of the cormorant, which, after many attempts, and much struggling, was killed by it. When they were taken up, I opened the bird's throat, and measured the fish, which was one foot and half an inch in length; the spines long, sharp, and strong, bared of the skin, with which they are ordinarily covered, by the struggles of the bird, and the longest fastened in its throat, so that we could not withdraw them till we cut up the belly.

The shape of this fish is conical ; the head and shoulders very thick, growing smaller to the tail. The colour is very different, being in some red, most beautifully marbled with a bright white, and other colours, in well-defined spots; in others the ground colour is dusky, and mottled with whiteand red ; in some the belly is a fine white, in others a bright yellow; the fins are all transparent, but spotted with brown or black.

The pectoral fins are very large and broad; the fish erects them when in danger, or when taken; there are two fins on the back, the first hard rayed, the other soft; the ventral small and long; the anal broadest in the middle, narrowing to each end ; the tail round.

This fish is reckoned delicate eating, and those who can 
[Fishes.

put up with its horrid appearance, prefer it to others which are more beautiful to the eye.

\section{GENUS XVI.-THE DOREE.}

Gen. Char.-Body very deep, and compressed sidewise; very long filaments issuing from the first dorsal fin; seven branchiostegous rays.

\section{Species 1.-The Opah.}

Opah or King-Fish, Phil. Trans. Abridg. Vol. XI. 879, tab. 5. Piscis maculis aureis aspersus non scriptus, pollices 42 longus, Sib. Scot. tab. 6, fig. 3. Wal. Disc. Orc. 37. Brit. Zool. III. 201. Brit. Zool. Illus. IV. 76, tab. 91. fig. 2.

Mr Wallace, in his Description of Orkney, gives an account of this fish; and I suppose it was from him Sir Robert Sibbald had it, as the plate in both is the very same, and seems to have been made from the same drawing.

This Mr Wallace describes was taken in Sanda, in the winter 1682 ; and he tells us several had been gotten there before. According to the description "It was about an ell in length, " deep-breasted, and narrow to the tail ; the head and fins, " and a stroke down the back, were of a deep blood-colour.". " The rest," says Mr Wallace, "was mouse-coloured, having " several whitish spots on the body." 
In the British Zoology it is thus described : "The weight " between seventy and eighty pounds ; shaped like the sea" bream ; the length three feet and a half; the breadth, from " back to belly, almost two feet; but the thickness, from " side to side, not above six inches.

"The mouth small for the size of the fish, forming a square " opening, and without any teeth in the jaws; the tongue " thick, resembling that of a man, but rough, and thick " set with barbs or prickles, pointing backwards, so that " any thing might easily pass down, but could not return " back ; therefore, these might serve instead of teeth to retain " its prey; the eyes remarkably large, covered with a mem" brane, and shining with a glare of gold; the cover of the " gills like a salmon.

"The body diminishes very small to the tail, which is " forked, and expands twelve inches; the gill-fins are broad, " about eight inches long, and play horizontally ; a little be" hind their insertion, the back-fin takes its original, where " it is about seven inches high, but slopes away very sudden" ly, running down very near the tail, and at its termination " becomes a little broader; the belly-fins are very strong, and " placed near the middle of the body; a narrow fin also runs " from the anus to the tail.

"All the fins, and also the tail, are of a fine scarlet; but " the colours and beauty of the rest of the body, which is " smooth, and covered with almost imperceptible scales, beg. " gars all description, the upper part being of a bright green, " variegated with whitish spots, and enriched with a shining D d 
" golden hue, much resembling the splendour of the peacock's

" feathers ; this, by degrees, vanishes into a bright silver, and " near the belly the gold begins again to predominate in a " lighter ground than on the back."

I have only to add, that this fish seems to be very rare, and never caught with a hook, and but seldom thrown ashore, as in seven years $I$ have never heard of a specimen of it got in the Orkneys, so am obliged to others for the above, and even the knowledge of its being an Orkney fish. There are, indeed, very many curious fishes thrown ashore in the winter storms, and many of these, I believe, little known, but scarce ever taken notice of by our people, except they are such as they know to be fit for eating; the others are left for the gulls.

Mr Wallace adds to his description of the Opah, that " the flesh of the half next the head was like beef, and of the " other half like salmon." He has a figure which is the same with Sibbald's, and, for the time in which it was made, tolerably well.

Mr Pennant, Vol. IV. says, it ought to be removed from the genus he had placed it in, in his Zoology, into that of Doree, where I suppose he will place it in the next edition of his valuable work. 


\section{GENUS XVII.-THE FLOUNDER-KIND.}

Gen. Char.-Body quite flat, and very thin; eyes both on the same side of the head; branchiostegous rays, from four to seven.

* With the Eyes on the right side.

Species 1.-The Holibut.

Holibut, Septent. Anglis Turbot, Wil. Icth. 99. Raii Syn. Pisc. 33. Pletlronectes Hippoglossus, Lin. Sys. 456. Brit. Zool. 184. Orc. Turbot.

THE Holibut is very frequently caught by our fishermen round the whole country, but especially in the eddies, or where two tides meet : all the flat fishes, by their shape, being hindered from resisting the rapidity of the tide, are obliged to withdraw themselves till its force is spent, and are often at this time caught by the fishermen, who know this circumstance.

They are very large and coarse dry fish, except the head and fins, which are reckoned excellent; yet a very small fish of this kind is far from bad. The skin is thick and oily, as also the bones, from which a large quantity of pure oil may be obtained. Whether this is for any particular use, I am uncertain. 
Plaise, Wil. Icth. 96. Raii Syn. Pisc. 31. Plueronectes Platessa, Lin. Sys. 456. Brit. Zool. 186.

LIKEWISE caught here, though not very large. The skin is a little rough, without scales; has six tubercles behind the left eye.

The body is broader, in proportion to its length, than several of the other species of this genus; the colour of the upper side brown, with orange and red spots ; the belly white.

This species keeps much on the sand-banks and muddy grounds; found frequently on the bank of the harbour of Stromness, and at the top of the bay, likewise in the bay of Skeal, and other flat sandy shores round the Orkneys. A few are caught on small lines made on purpose, but they are not much sought after.

\section{Species 3.-The Flounder.}

Flounder, Fluke, or But, Wil. Icth. 980. Raii Syn. Pisc. 32 Pleuronectes Flesus, Lin. Sys. 437. Brit. Zool. 187.

This is found in all our bays, creeks, and inlets, especially if the ground be flat and sandy; also very frequent in the shallower parts of the loch of Stenness, where I have seen 
vast numbers of them caught with a seine net, of different dimensions, from half a pound to two or three, seldom exceeding the last.

It is very delicate eating, especially fried, and most commonly here dressed in this way.

The back is rough, with rows of prickles, which are placed at the beginnings of the rays of its fins, and on the side line ; the colour of the back is brown; the belly white.

\section{Species 4.-The Sole.}

Solea, the Sole Fleuk, Sib. Scot. 24. Pleuronectes Solea, Lin.Sys. 457. Brit. Zool. 190.

Easily distinguished from the rest of the genus, by being the narrowest, in proportion to its length, of any of them.

The scales are small, armed with prickles at one end, which makes the fish feel rough to the hand; they are commonly shewn as curiosities in a microscope, enclosed between two bits of talc, fixed in a slider. The colour of the back is brown; the belly white, but more transparent than in several others of the flounder-kind.

The sole is reckoned the most delicate of the genus, and much valued. They are caught in the bay of Skeal, and no doubt elsewhere round the Orkneys. 
* With the Eyes on the left side.

Species 5.-The Turbot.

Turbot, in the North a Bret.Wil. Icth.94. Rhombus maximus asper non squamosus, Raii Syn. Pisc. 31. Pleuronectes maximus, Lin. Sys. 459. Brit. Zool. 192.

The true Turbot is perhaps found on our coasts, though but rare, insomuch that in these seven years I have but seen two or three specimens. These are much better fish than the great holibut, but the latter is much more frequently caught, and sometimes of an enormous size: I have seen a holibut seven feet and a half long, and very thick in proportion, but very coarse; those of two or three feet being much better.

Though there are great numbers of these holibuts caught here, they have no method of preserving them, either by pickling or drying them, and I suppose they would make but very ordinary eating cured in either way. 


\section{GENUS XVIII.-THE WRASSE.}

Gen. Char.-Covers of the gills scaly; branchiostegous rays, unequal in number; teeth conic, long, and blunt at their ends; one tuberculated bone at the bottom of the throat; two above opposite to the other; one dorsal fin reaching the whole length of the back; a slender skin extending bejond the end of each ray; rounded tail.

\section{Species 1.-The Wrasse.}

Turdus vulgatissimus, Wil. Icth. 319. Wrasse or Old Wife, Raii Syn. Pisc. 136. Labrus Tinca, Lin. Sys. 477. Brit. Zool. 203. Orc. Bergle.

Fou ND close in with the shores where they are highest, and deep water, along with the red cod, and some others; not very often caught here, though it will take a bait.

In shape it is short, deep, and thick, covered with very large scales, the greatest, indeed, I have observed on any fish, great or small.

They are much thought of as a food ; however, are something coarse, and thick skinned; are here roasted fresh, seldom or ever salted, the quantity got being so small as not to be worth curing.

The colour is red on the sides, and yellow bellied in some, while others vary, having the belly white, and only stripes or spots of red on their great scales. 


\section{GENUS XIX.-THE STICKLEBACK.}

Gen. Char.-Three branchiostegous rays; the belly covered with bony plates; one dorsal fin, with several sharp spines between it and the head.

\section{Species 1.-The Three Spined Stickleback.}

Stickleback, Banstickle, or Sharpling, Wil. Icth. 341. Raii Syn. Pisc. 145. Gasterosteus aculeatus, Lin. Sys. 489. Orc. Brandstickle.

Found commonly in every the smallest running brook, loch, or puddle, that has a running communication with any other piece of water.

Seldom found above two inches in length; the belly large and prominent, especially when the females are full of roe; the sides and belly are covered with hard plates till near the tail, when the body turns small and square.

On the back are three sharp spines, moveable at the pleasure of the fish; it has one back-fin placed pretty far back. Whether this fish can be said to have ventral fins, I am in doubt, as these consist of a hard spine on each side, folding down on the belly on a hard pointed plate, which reaches almost to the vent; the anal fin begins near the vent, having a short spine before it; the tail even.

The colour of the back green ; of the belly, white or red; 
in some the whole belly is of the latter colour, in others only the lower jaws.

The spines are rough, with small prickles along their edges, moveable by strong muscles.

\section{Species 2.-The Fifieen Spined Stickleback.}

Aculeatus marinus major, Schonveldi, Sib. Scot. 24, tab. 19, fig. 2. Idem. Wil. Icth. 340. App. 23. Raii Syn. Pisc. 145. Gasterosteus Spinachia, Lin. Sys. 492. Brit. Zool. 220. Brit. Zool. Illus.tab. 42. Orc. Bismore.

Found very frequent in the sea; has its Orkney name from the kind of balance here made use of, called Bismores.

The mouth is a long snout; the rictus small; the eye large, as in all in the kind; the body, which in some specimens is six inches long, is covered with hard crusty scales, pretty thick to the vent, when it grows very small to the tail, for about an inch or more before which it is square.

From the back of the head runs a row of fifteen spines, to the beginning of the back-fin : the back and anal fins are opposite to one another ; no ventral fins. In my drawings of this fish are two small spines placed opposite to one another instead of these, and a single one before the anal fin ; the tail is even at the end.

The colour of the body, to the side line, is brown, or, in young ones, green ; the belly white.

These fishes enter into no part of our economy, they are too Ee 
small and crusty to make a dish of ; the same fault may be objected against making a bait of them. They are got in no quantities to use them as a manure, which $\mathrm{Mr}$ Pennant tells us they do elsewhere*, and, in a word, no profit can be made of them any way.

\section{GENUS XX.-THE MACKEREL.}

Gen. Char.-Seven branchiostegous rays; several small fins between the dorsal fin and the tail.

\section{Species 1.-The Mackerel.}

Mackrell or Macarel, Wil. Icth. 181. Raii Syn. Pisc.58. Scomber Scomber, Lin. Sys. 492. Brit. Zool. 221. Brit. Zool. Illust. tab. 98, fig. 2. Sib. Scot. 24.

MackereL set into our sounds in vast shoals the last week of July, or first of August. I have been informed by sea-faring people of their falling in with the beginning of the mackerel shoal a good way to the eastward of Copinsha, and it has continued till they came within the sound called Ham Sound : this in the first week of August.

Notwithstanding of the quantity, and the certainty of the 
capture, our people never trouble themselves about them, except they happen (and this is but seldom), to fall in with them by chance.

This is a most beautiful fish, whether we consider the elegance of its make or the excellence of its colours.

The nose is sharp ; the lips equal; the body is full, tapering much to the tail, where it is ridged.

The back-fin consists of a few stiff rays, the second of soft ones; between it and the tail are five spurious fins; and between the anal fin and the tail as many.

This is one of the finest fishes for the table we have, while fresh, but soon loses both its outward beauty and its flavour if kept but for a short time. It is sometimes fried, but in this manner it is but ordinary. 


\section{Abdominal.}

\section{GENUS XXI. THE SALMON.}

Gen. Char.-Branchiostegous rays unequal in number; two dorsal fins, the second thick, and without rays.

* With Teeth.

\section{Species 1.-The Salmon.}

Salmon, Wil. Icth. 189. Raii Syn. Pisc. 63. Salmo, Salar, Lin. Sys. 569. Brit. Zool. 239. Brit. Zool. Illus. 77, tab. 93.

What a pity it is that 1 am almost obliged to deny the Salmon a place in the Orkney Zoology; yet true it is, that this noble fish is so seldom got here, that it is considered as a wonder when one is thrown ashore, or runs so far up one of our burns as to be taken. I have not heard of above three or four instances of salmons being got in Orkney, three of which (if they were all salmon) were killed and brought on shore by the otter from the sea, and picked up by the country people, and a fourth which stuck in a mill-wheel, and was caught by the miller.

I have been informed of a salmon-fishing on the mouth of the loch of Stenness, and of heritors who have such a fishing 
in their charters; the old people too shew us a place where cruives were placed; but if ever there has been any thing of this kind here, it has, I imagine, been far from considerable, and long since given up ; and, indeed, the nature of our country will not allow salmon-fishings in fresh waters, as there is not a single stream in the country where a salmon could be safe, even for an hour, except the loch of Stenness; but it is is well known that salmon delight much more in clear running streams, than muddy lochs ; besides, the entrance is so foul and narrow, that, except when the tide is up, none could enter it.

I have no doubt but there are salmon in the sea, and some few of these might be caught, if our folks had the method of fishing them. It is very certain that vast quantities of salmon are caught in the rivers of Caithness, which are right against, and only the frith betwixt them and Orkney; therefore, though the former has the advantage over us in its inland rivers, yet I should think, at the same time of the year, when the fish begin to betake themselves to the bays, in search of the mouths of rivers, we might have a chance to get some small quantity as well as our neighbours.

It is certain our bays abound with congenerous fish of several kinds; why then may we not think the salmon at this time pays us a visit, but not finding proper accommodation, retires to more hospitable shores. 
Species 2.-The Bull Trout.

Trutta Salmonata, the Salmon Trout, Bull Trout or Scurf, Raii Syn. Pisc. 63. Wil. Icth. 193, 198. Salmo Trutta, Lin. Syst. 509. Brit. Zool. 249.

Thrs species is found in great quantities in the loch of Stenness through the whole summer, especially in that part of it which is called the Harra Loch.

These grow not to so large a size as the true trout (here called Burn Trout), which are found in the very same places as the former; but these not so much esteemed, as the flesh is always white, and but ordinary. However, there is seldom any distinction made among our commons, but all are eaten.

These, as well as others, are caught in small houses, built on our burns, into which the fish can easily make his way, but cannot so easily get back again. However, this is only practicable in harvest, when they begin to make their way into the very smallest burns, in order to spawn.

They lose season on spawning, and immediately betake themselves to the sea. 
Species.3.-The Trout.

A Trout, Wil. Icth. 199. Raii Syn. Pisc. 65. Salmo Fario, Lin. Sys. 509. Brit. Zool. 250, Illus. pl. 40.

Found in every burn in great plenty, so common as to need no description. Seldom grows very large in our burns. I have heard of a species of trout got in some of the lakes, both here and in Shetland (but what species I know not), weighing twenty-three to thirty-six or more pounds; but these, I dare say, are uncommon.

\section{Species 4.-The Parr.}

Brit. Zool. III. No.

Pretty frequent in the shallower lakes and clear burns, though not in such numbers as I have observed them in Scotland. Seldom grows above six inches in length. What distinguishes this from the other species of trout, is a row of large bluish spots on each side, lying transversely along the side line, which is peculiar to this fish. 


\section{Species 5.-The Char.}

Wil. Icth. 196. Raii Syn. Pisc.65. Lin. Sys. 510. Brit. Zool. 256, pl. 15.

VERY infrequent with us, though sometimes seen in the loch of Stenness. I have not seen above a couple of specimens. Perhaps we know not the method of catching them, or the season may differ here from other places where they are found. However this is, they are not much known.

It is the beautiful red on the belly which distinguishes them from the other trout of the loch, and is a sufficient mark to strike the most inattentive observer.

Species 6.-The Grayling.

A Grayling or Umber, Wil. Icth. 187. Raii Syn. Pisc. 62. Salmo Thymallus, Lin. Sys.512. Brit Zool.262.

Turs species is found very frequent with us; caught with a fly, to which it rises very freely, and struggles hard for life. Swims very quick; leaps much, especially when struck with a hook, when the nieest hand is required to hinder its breaking the line, nor is it easily tired.

This species is caught of different sizes, from a foot to eighteen inches long. 


\section{GENUS XXII.-THE ARGENTINE.}

Gen. Char.-Teeth in the jaws and tongue; eight branchiostegous rays; vent near the tail; the ventral fins composed of many rays.

Species 1.-The Argentine.

Pisciculus Romæ Argentina dictus, Wil. Icth.229. Raii Syn. Pisc. 108. Argentina Sphyræna, Lin. Sys.518. Brit. Zool.276. Brit. Zool. Illus. 42, tab. 48.

TH Is beautiful little fish was given me by a boy, who said he found it in the edge of the water, among the sea-ware.

It was not above an inch in length; seemed very delicate; the colours good; the back greenish, spotted with darker clouds; the belly a fine silver; but it lost all its fine colours when kept dry.

All the fins were soft; and the tail membrane, as well as those of the other fins, was very thin.

I suppose these are scarce on our coasts, as I never saw but this one. 


\section{GENUS XXIII.-THE HERRING.}

Gen. Char.-Eight branchiostegous rays; the belly extremely sharp, and often serrated.

\section{Species 1.-The Herring.}

Herring, Wil. Icth. 219. Raii Syn. Pisc. 103. Clupea Harengus, Lin. Sys. 522. Brit. Zoot. 284, tab. 17. Sib. Scot.23.

ALL writers who have taken the least notice of the Natural History of the Orkney Islands, tell us of the numerous swarms of herrings that are to be found amongst them. $\mathrm{Mr}$ Wallace says, in his time, or some years before, many ships from Fife frequented this country for catching of herring, but that the skippers and seamen being at the battle of Kilsyth, were almost all killed, since which time the trade failed; and indeed, these many years no herrings have been caught in Orkney, not so much for want of them, as (I imagine) that oddity, so firmly implanted in human nature, which compels us to hunt through the whole world for things which we may have at our own doors.

I am well informed by seamen, they have met the herrings on our coasts; I have heard of them setting as far into our sounds as Scalpa Bay. There are fishings of herrings all round us, - the Shetland Isles swarm with them in April, and 
later,-the east coasts of Caithness, in August,-the Hebrides, latter end of the year, - and the more southerly parts of Britain, as they proceed in their expedition. Now, notwithstanding of their acknowledged capriciousness in their annual migrations, it would be folly to think they do not take our isles in their way, while they pass in such great numbers on each side of us.

Another proof that they are with us is, that at certain times our sounds swarm with their fry; and these sometimes run so far into the bays, that $I$ have caught great numbers of these in June, about six, seven, or eight inches long, in the fresh water at the mouth of the loch of Stenness; and have seen in the same place several barrels taken by the country people, who have nets for the purpose.

Within these few years past, our vessels have gone to a place called Staxigo, on the coast of Caithness, where they have had good success in fishing herrings, which makes me hope, as they see they are to be got so near home, they will at length attempt them in their own bays, where I should imagine there was just as great a probability of succeeding as anywhere else, provided they are once acquainted with the time of their setting into the bays of the Orkneys; for it is well known the herring is a fish which makes no long stay in one place, and if not attended to while to be found, all is over for the season. But till these, and many other precautions, be used, we can only say with Martin, Wallace, \&c. "They are " here, but, alas, they are neglected!"

Whether any other of this genus appear here, I ain altogether uncertain. 
[Fishes.

I have not the least doubt but many other both curious and valuable fish are to be found here, though they have not yet come to my knowledge, as it is scarce possible for any one person to investigate all, though ever so diligent; and here, though indolence prevails very much, yet we are much fonder of ordinary than curious fish, and many of the latter, though taken, are never perhaps brought ashore, but immediately thrown overboard, or, if they are brought ashore, little minded. If, therefore, a set of intelligent people, at different places of the country, would take the trouble of observing, and of communicating their observations to each other, this would have a great effect to form a complete natural history of particular places, from which might be compiled a general history of the whole islands of Britain; but this never can be done by one, without the help of many. 


\section{ADDENDA.}

\section{The Gemmeous Dragonet.}

Lin. Sys. 433. Brit. Zool. 130. Illus. pl. 30.

I Found a specimen of this fish entangled among the seaware, and which is the only one I ever saw. It was about six inches long, the head large, and flat; the body conical. The breast fins large, as are the ventral. But what struck me, was the first back-fin, the first ray of which is so long as to reach the tail, and is sufficient to distinguish it from all the Orkney fishes.

\section{The Gray Gurnard.}

Lin. Sys. 497. Brit. Zool. 231. Illus. pl. 38.

THE Gurnard is caught by shipping as they approach these isles, and all round them, by hanging a hook and baited line over the stern in a brisk breeze, at which this fish (which is a very quick swimmer), bites, and is caught for the firmness of its fish. When they are hauled on board, they make a sort of croaking plaintive noise, something like an angry person growling to himself, and this for some time.

G $g$ 
Before they can be dressed, the skin must be taken off, which is prickly about the head and fins.

\section{The Saury.}

\section{Pen. Tour, 1st ed.p. 284.}

LAsT year (1775), such a glut of these fish set into the head of Kerston Bay, that they could be caught in pailfuls. Numbers were caught, and heaps flung ashore. Our seamen called them Garfish, and said they were frequent on the coast of America. They were remarkable for a set of false fins between the back and tail-fin, and between that and the anal below. They differed in bulk, but were from nine to twelve inches long. 'The mouth was like the bill of a bird, horny, and projected into two recurved mandibles. The colour on the back a dark green; the belly silver-coloured.

No man living near the place where they set in, remembered any of the kind in these seas; so that it is probable they had drove out of their way, and not knowing how to recover it, had run among these isles, where many of them perished, and very few of the shoal got to sea.

THE END.

Prunted by G. Ramsay \& Co.

Edinburgh, 1812. 




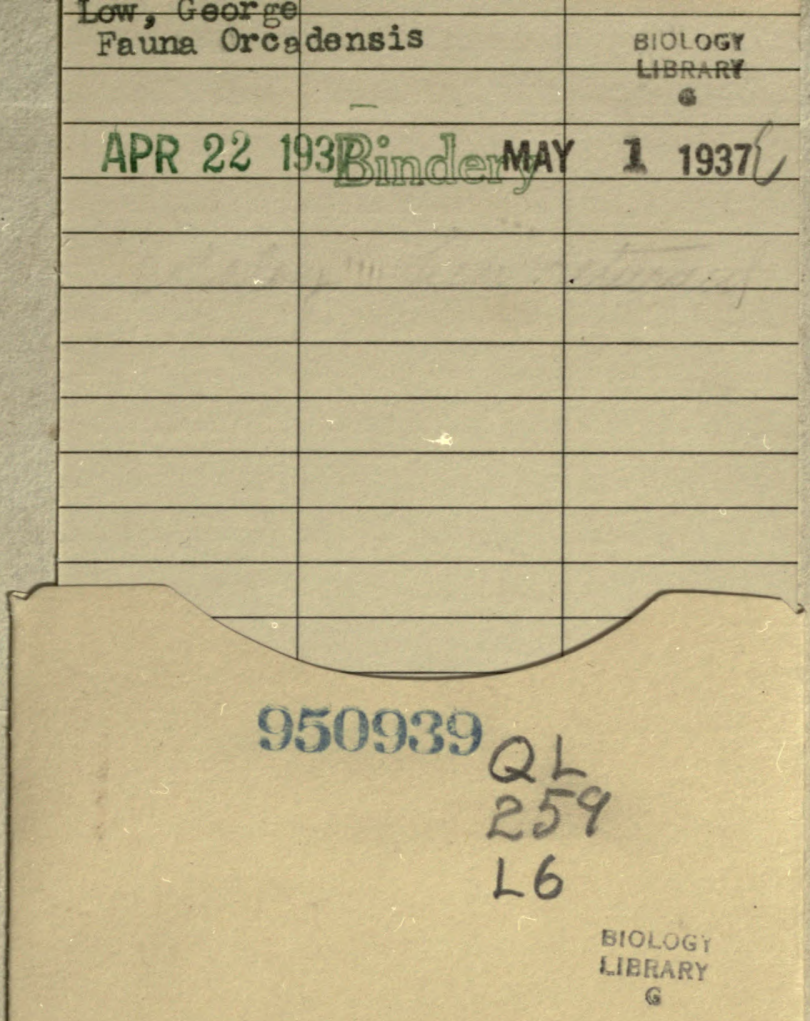

THE UNIVERSITY OF CALIFORNIA LIBRARY 
